\title{
The Research on Porphyrins and Analogues in Brazil: A Small Review Covering Catalytic and other Applications since the Beginning at Universidade de São Paulo in Ribeirão Preto until the Joint Venture between Brazilian Researchers and Colleagues from Universidade de Aveiro, Portugal
}

\author{
Shirley Nakagaki, ${ }^{* *, a}$ Kelly A. D. F. Castro, ${ }^{b}$ Maria da Graça P. M. S. Neves, ${ }^{*, c}$ \\ Maria do Amparo Faustino ${ }^{c}$ and Yassuko Iamamoto ${ }^{* d}$ \\ ${ }^{a}$ Laboratório de Bioinorgânica e Catálise, Departamento de Química, Centro Politécnico, \\ Universidade Federal do Paraná (UFPR), Av. Cel. Francisco H. dos Santos, 100, \\ Jardim das Américas, 81531-980 Curitiba-PR, Brazil \\ ${ }^{b}$ Departamento de Física e Química, Faculdade de Ciências Farmacêuticas de Ribeirão Preto, \\ Universidade de São Paulo (USP), Avenida do Café, s/n ${ }^{\circ}$, 14040-903 Ribeirão Preto-SP, Brazil \\ ${ }^{c}$ QOPNA \& LAQV-REQUIMTE, Department of Chemistry, University of Aveiro, \\ 3810-193 Aveiro, Portugal \\ ${ }^{d}$ Departamento de Química, Universidade de São Paulo, Av. Bandeirantes, 3900, \\ 14040-901 Ribeirão Preto-SP, Brazil
}

\begin{abstract}
The synthetic versatility and the potential applications of porphyrins and analogues in different fields have aroused special interest in their study, especially to mimic biological systems, such as cytochrome P-450. The ability of the porphyrin tetrapyrrolic core to accommodate metal ions of varying charges can modulate the type of application of these compounds. As a contribution, in this special number in honor to the Brazilian women who have devoted their lives to the growth and dissemination of chemistry knowledge, we report the advances in porphyrin research in Brazil for catalytic purposes and other applications, beginning at the Universidade de São Paulo (USP) at Ribeirão Preto. We also discuss some works that have resulted from joint research effort between Brazilian researchers and Portuguese colleagues from the Universidade de Aveiro, Portugal, working in the porphyrin field.
\end{abstract}

Keywords: metalloporphyrin, cytochrome P-450, catalysis, oxidation, photosensitizer

\section{Introduction}

1.1. Porphyrins and other tetrapyrrolic macrocycles as models for catalytic action of cytochrome P-450

Cytochrome P-450 is a family of hemeproteins with unusual spectroscopic properties that is extracted from liver microsome cells, ${ }^{1-3}$ initially studied by Omura and $\mathrm{Sato}^{4}$ in the 1960s. Many subsequent studies showed that it is a superfamily of isoform enzymes present in a wide array of organisms, and it is involved in different oxidative metabolic processes like biosynthesis of hormones and detoxifications of xenobiotics. The oxidation of a large variety of organic compounds mediated by this type of pigment occurs in the

*e-mail: shirleyn@ufpr.br, gneves@ua.pt; yassuko.iamamoto@gmail.com presence of oxygen and of a reducing agent., 5 The active site of this family of catalytic hemeproteins was identified as being based on the iron complex of protoporphyrin IX, usually known as the heme group (Figure 1).

The macrocycle present in the heme group, constituted of four pyrrole units linked by four methinic bridges and known as porphyrin, has a cavity with diameter of about $4.0 \AA$. Besides iron, these macrocycles are capable of accommodating more than 50 metal ions with different oxidation numbers and spin states, leading to the formation of stable complexes named metalloporphyrins (MPs). ${ }^{7}$

In the last three decades of the twentieth century, researchers from various fields, such as chemistry (including organic and inorganic chemistry), biochemistry, physics, endocrinology, nutrition, toxicology, oncology and pharmacology, devoted extensive studies to elucidate 


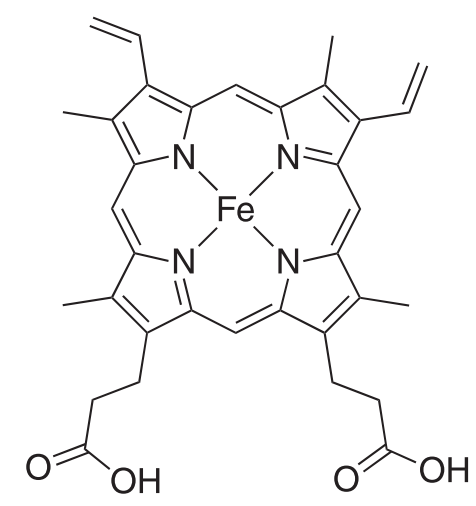

Figure 1. Structure of the heme group.

the action mechanism of oxidative metabolic processes mediated by cytochrome P-450, ${ }^{5,8-10} \mathrm{~A}$ central issue was to unravel the mechanism by which the P-450 family members catalyze the chemical transformations, with an important challenge being identification of the intermediate species involved in oxygen activation.

Groves and $\mathrm{McClusky}^{11}$ used substrate diagnostic techniques to study aliphatic hydroxylation using purified liver microsomal cytochrome P-450. The results indicated that the hydroxylation mechanism is a step-wise process involving the active oxygen species $\mathrm{FeO}^{3+}$, formally $\mathrm{Fe}^{\mathrm{V}}-\mathrm{P}-450$ (Figure 2). This species abstracts hydrogen from $\mathrm{R}-\mathrm{H}$ substrate to give $\left[\mathrm{R} \cdot \mathrm{FeOH}^{3+}\right.$, a cage system which collapses to form Fe ${ }^{\mathrm{III}} \mathrm{P}-450$ and alcohol. ${ }^{12}$

\section{Iron(IV)-oxo porphyrin p-cation radical}
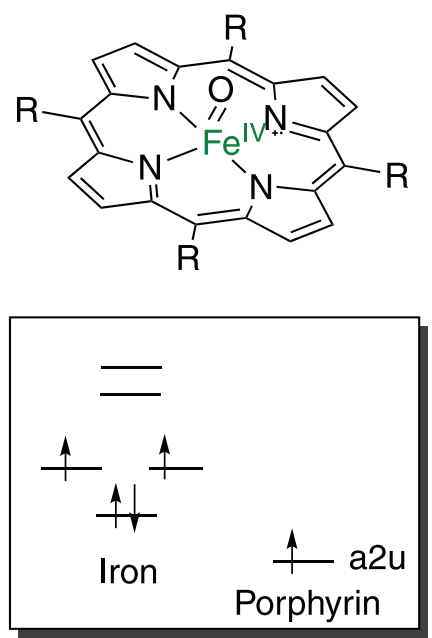

Figure 2. Possible intermediate species involved in the catalytic cycle of P-450 enzyme. Green species proposed as an iron(IV)-oxo porphyrin $\pi$-cation radical, $\mathrm{Fe}^{\mathrm{IV}}(\mathrm{O}) \mathrm{P}^{\circ+}$ (formally $\mathrm{Fe}^{\mathrm{v}}-\mathrm{P} 450$ ).

The first evidence of a compound I-like intermediate, an iron(IV)-oxo porphyrin $\pi$-cation radical, $\mathrm{P}-450$ compound I (P450-I) (Figure 2), equivalent to compound I of HRP (horseradish peroxidase enzyme), was provided by Egawa et al. ${ }^{13}$ in 1994 in studies involving the reaction of meta-chloroperbenzoic acid ( $m$ CPBA) with low-spin ferric P-450cam. In 2010, Rittle and Green ${ }^{14}$ reported the spectroscopic and kinetic characterization of the intermediate involved in the oxygenation process, $\mathrm{P}-450$ compound I (P-450-I), which was prepared from the reaction of ferric CYP119 with $m$ CPBA. It was similar to chloroperoxidase compound I.

P-450 can promote the monooxygenation of substrates using oxidizing reagents such as peroxides, ${ }^{15-17}$ periodates, chlorites ${ }^{17}$ and iodosylarenes (ArIO). ${ }^{18,19}$ These oxidants can act as single oxygen atom donors, involving two-electron

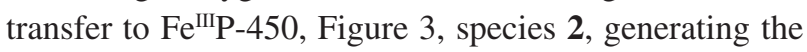
active species P-450-I, Figure 3, species 7, directly via the peroxide shunt pathway, considering the catalytic cycle of P-450. ${ }^{6,14,20-24}$

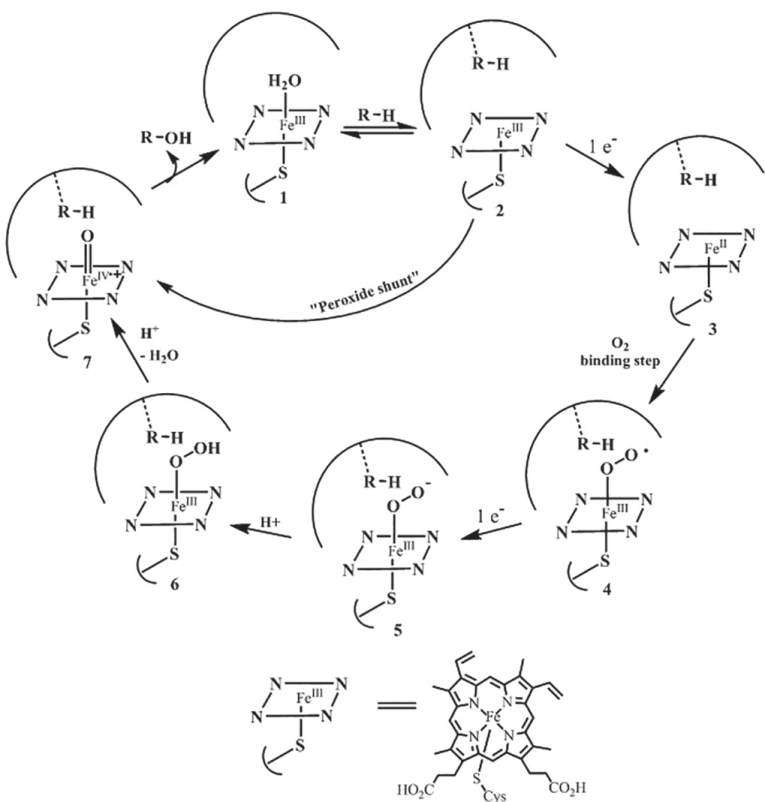

Figure 3. Catalytic cycle of cytochrome P- 450 including the shorter peroxide shunt $(\mathrm{P}-450$ protein part $=$ semicircle representation; $\mathrm{R}-\mathrm{H}=$ substrate for the catalytic reaction). ${ }^{20}$

Ortiz de Montellano 5 in 2010, after reexamining the theoretical and experimental results for the P-450 oxygenation mechanism compiled up to that time, reaffirmed that the compound I-P-450 species $\mathrm{Fe}^{\mathrm{IV}}(\mathrm{O}) \mathrm{P}^{++}$is the primary oxidant and the radical rebound mechanism is the way oxygen atoms are inserted for the hydroxylation process.

Inspired by the efficacy of oxygen donor oxidants to react with P-450, affording the active species P-450-I, Figure 3, species 7 , through the bypass shunt without requiring the presence of a reducing agent and oxygen, Groves et al. ${ }^{25}$ reported in 1979 the hydroxylation and epoxidation transformations catalyzed by iron-porphyrin complexes. The selectivity results indicated that the synthetic ironporphyrins/ 
iodosylbenzene $(\mathrm{PhIO})$ system constituted a surprisingly good P-450 biomimetical approach.

The synthetic versatility and the potential applications of metalloporphyrins in different fields have in the past four decades attracted researchers from different countries, including Brazil, to study these complexes, especially to mimic biological systems such as cytochrome P-450. ${ }^{26}$

The ability of porphyrin's tetrapyrrolic core to accommodate metal ions of varying charges can modulate the type of application of these compounds. ${ }^{27}$ For example, cobalt porphyrins were described as catalysts for the amination of 1,2-dihydronaphthalene derivatives, ${ }^{28}$ ruthenium porphyrins in the enantio- and regioselective epoxidation of olefinic double bonds in quinolones, pyridones and amides ${ }^{29}$ and in cyclopropanation and amination reactions; ${ }^{30}$ nickel porphyrins as electrocatalyts of water oxidation to $\mathrm{O}_{2} ;{ }^{31}$ and many others such as tin, zirconium, titanium and aluminum. ${ }^{32-37}$

In the field of catalysis, synthetic metalloporphyrins, mainly the complexes with $\mathrm{Mn}^{\text {III }}$ and $\mathrm{Fe}^{\text {III }}$ ions, proved able to successfully oxidize hydrocarbons and other organic compounds under mild conditions. ${ }^{25}$ They are able to act as chemical models of the P-450 enzyme family using oxygen donors, not only PhIO, as shown by Groves et al., ${ }^{25}$ but also $\mathrm{H}_{2} \mathrm{O}_{2}$ and $\mathrm{PhI}(\mathrm{OAc})_{2}$, since they are able to catalyze the transfer of one oxygen atom from these oxidants to a metal complex in various oxidative reactions, leading to the formation of the catalytically active species. ${ }^{38}$

Cooper and Groves ${ }^{23}$ studied the oxidation of the diagnostic substrate tetramethylcyclopropane with important drug-metabolizing cytochrome P-450 isozymes and with a model cationic ironporphyrin/iodosylbenzene system and concluded that: "The similarity of the observed behaviour of the model system and the active enzymes indicate that similar mechanisms and similar intermediates are involved in both cases." ${ }^{23}$

\subsection{Brief historical events}

In 1981, Nicholas Farrell and Antonio A. Neves ${ }^{39}$ from Universidade Federal de Minas Gerais published one of the first articles from Brazil on the porphyrin theme. It was a landmark for chemists in this field, since the work reported the first preparation of aryldiazenato ruthenium porphyrin complexes formed by direct reaction with aryldiazonium ions. ${ }^{39}$ In this report, for the first time the synthetic porphyrins octaethylporphyrin (OEP) and meso-tetraphenylporphyrin (TPP) macrocycles were prepared and used as ligands in Brazil. Before them, the Brazilian biochemists Ohara Augusto and Etelvino J. $\mathrm{H}$. Bechara ${ }^{40}$ reported the use of commercial hemin and deuterohemin for the catalytic generation of triplet acetone, mimicking the action of horseradish peroxidase (HRP) as a catalyst for the aerobic oxidation of isobutyraldehyde (methylpropanal) to acetone and formate..$^{40}$

In 1979, John Malin, at the time an advisor to the National Science Foundation (USA), visited the Universidade de São Paulo, Ribeirão Preto Campus (Brazil) and suggested a postdoctoral internship to Y. Iamamoto in the Porphyrins and Metalloporphyrins Chemistry Laboratory of Prof T. G. Traylor at the University of California at San Diego (UCSD, USA). The work done during this internship started in 1981 with the project "Mechanisms of Oxygenase Reactions of Cytochrome P-450 and Model Compounds". At that time, the problem of the P-450 catalyzed oxidation reaction research was to understand whether oxygen transfer was carried out in one or two electron steps or if it was preceded by electron transfer from the substrate. In order to clarify this point, Traylor proposed to study a P-450 mimic system using as substrate the strained (E)-cyclooctene, [ $\mathrm{Fe}(\mathrm{TPP})] \mathrm{Cl}$ (Figure 4, R=1) as catalyst and 2,4-dimethyl-iodosylbenzene as oxygen donor. The results, published in Journal of the American Chemical Society in 1986, ${ }^{41}$ indicated that epoxidation occurs with electron transfer from the substrate to the active high-valent iron-oxo species, identified as $\mathrm{Fe}=\mathrm{O}^{+}$, which corresponded to $\mathrm{Fe}^{\mathrm{IV}}(\mathrm{O}) \mathrm{P}^{++}$(Figure 2). The oxidations were found to occur mediated by a carbocation intermediate with ferryl species, in an oxymetallocycle rearrangement, followed by cage collapse. It was possible to explain the results with a single mechanism, in which the oxymetallocycle intermediate decomposes in different ways, explaining the products obtained. Ortiz de Montellano and Stearns ${ }^{42}$ also showed evidence of radical cation intermediates for the P-450-catalyzed oxidation of quadricyclane.

In this regard, the researchers found that the FeTPPCl-ArIO system was an effective P-450 model. The article, entitled "The mechanisms of hemin-catalyzed oxidations: rearrangements during the epoxidation of $(E)$-cyclooctene", was the first report involving a Brazilian researcher Y. Iamamoto, in the context of using metalloporphyrins as biomimetic catalyst to model the enzyme family of cytochrome P-450. ${ }^{41}$

At that time, it was recognized that the high efficacy of reactions mediated by cytochrome P-450 enzymes (e.g., high rates, selectivity and stereospecificity) was difficult to achieve in simple chemical systems. ${ }^{43}$ A great deal of work had been done to elucidate the mechanisms of these enzymatic systems, namely by resorting to the use of synthetic systems as models for enzymatic activity. In fact, the discovery that cytochromes P-450 were capable of catalyzing the epoxidation and hydroxylation of 
unsaturated and saturated hydrocarbons, among others reactions, stimulated the search for simple systems based on iron(III) complexes of porphyrins (FeP) and other metalloporphyrins able to mimic these reactions.

Researchers such as T. G. Traylor, D. Dolphin, J. T. Groves, T. C. Bruice, D. Mansuy, P. Battioni, B. Meunier, J. A. S. Cavaleiro and J. R. Lindsay-Smith, among many others, have made important contributions in this field..$^{20,26,43-53}$

In 1981, Groves et al. ${ }^{44}$ reported the reaction of [tetrakis(mesitylporphyrinate)iron(III)]chloride, $[\mathrm{Fe}(\mathrm{TMP})] \mathrm{Cl}$ (Figure 4, R = 8) with $m \mathrm{CPBA}$, which produced the green and poorly understood catalytically active species involved in those oxidative processes. The structure of the green species, iron(IV)-porphyrin $\pi$-cation radical, $\mathrm{Fe}^{\mathrm{IV}}(\mathrm{O}) \mathrm{P}^{\bullet+}$ (Figure 2), was characterized. At the same time, Prof Traylor's group also observed the green species visually for the unhindered iron(III) porphyrin $[\mathrm{Fe}(\mathrm{TPP})] \mathrm{Cl}$ in the catalysis experiments. For Iamamoto, the contact with the rich metalloporphyrin chemistry in that laboratory at UCSD opened new perspectives and these studies can be considered the foundation of a long history of porphyrin chemistry in Brazil, with the participation of a new generation of researchers in this field.

In light of these brief historical facts, this review marks the $30^{\text {th }}$ anniversary of the Journal of the Brazilian Chemical Society (JBCS), by giving insight into porphyrin research in Brazil, especially that involving catalytic purposes. Besides that, it discusses some advances achieved in this topic in Brazil with the collaboration of researchers from Aveiro University, Portugal.

\section{Uses of Metalloporphyrins for Homoge- neous Catalysis}

As already mentioned, Groves et al. ${ }^{25}$ were pioneers in the use of synthetic metalloporphyrins in homogeneous catalysis for oxidation reactions. Since then, researchers have dedicated great efforts to the synthesis of metalloporphyrins that are more efficient, selective and resistant to the reaction conditions. ${ }^{54}$

The use of different synthetic metalloporphyrins as catalysts for oxidation reactions was explored by das Dores Assis et al. ${ }^{55}$ using the non-symmetrical iron porphyrin [5-(o-nitrophenyl-10,15,20-phenylporphyrinate) iron(III)]chloride [Fe(MNPP)]Cl as catalyst and $\mathrm{PhIO}$ as oxidant. The most important contributions of this work were the $70 \%$ yield in the selective hydroxylation of cyclohexane to cyclohexanol and the characterization of the dimer species $\mathrm{PFe}^{\mathrm{IV}}-\mathrm{O}-\mathrm{Fe}^{\mathrm{IV}} \mathrm{P}^{\bullet+}$ (or $\mathrm{PFe}{ }^{\mathrm{III}}-\mathrm{O}-\mathrm{Fe}^{\mathrm{IV}} \mathrm{P}^{\bullet+}$ ) in addition to the $\mathrm{Fe}^{\mathrm{IV}} \mathrm{OP}^{\bullet+}$ as active catalytic species. ${ }^{55}$
At the same time ${ }^{56}$ using $[\mathrm{Fe}(\mathrm{TPP})] \mathrm{Cl}$, an unhindered iron(III)porphyrin, the same dimeric species was detected, in addition to the oxoferryl porphyrin radical cation species. These species were characterized by bands at 564, 608 and $650 \mathrm{~nm}$ in the visible spectrum. The band at $650 \mathrm{~nm}$ was attributed to the porphyrin radical by Groves. ${ }^{11}$

Electron paramagnetic resonance (EPR) characterization was also important to support the identification of the species, with the contribution of Prof Nascimento of Instituto de Física de São CarlosUniversidade de São Paulo (IFSC-USP). In those studies, a large EPR signal at $\mathrm{g}=2.006$ (line width $\Delta \mathrm{H}=4.0 \mathrm{mT}$ ) was observed, due to the dimeric radical species. It was concluded that the orthogonality is retained through the formation of a $\mu$-oxo dimer, in which fifth and sixth ligands are the oxygen from the $\mu$-oxo bridge and the oxygen from ferryl. The ligands maintain the $\mathrm{Fe}^{\mathrm{IV}}$ in the $\mathrm{D}_{4 \mathrm{~h}}$ porphyrin plane, which prevents the magnetic coupling with the radical. Nevertheless, the proximity between the species allowed a magnetic dipole interaction, broadening the porphyrin radical-iron(IV) radical signal line width. ${ }^{55,56}$ For $\mathrm{Fe}^{\mathrm{IV}} \mathrm{OP}^{\bullet+}$ species there was no evidence of the porphyrin radical signal, due to coupling of the spin radical with $\mathrm{Fe}^{\mathrm{IV}}{ }^{43}$

In 1996 , Iamamoto et al. ${ }^{57}$ showed how the catalytic activity of the atropisomers of iron(III) complex of 5,10,15,20-tetrakis(tetradecyl-2-pyridyl)porphyrin, [Fe(TTD2PyP]Cl (Figure 4, R = 14) was affected by the solvent polarity. For this complex, it was proposed that the pyridinium rings have no free rotation due to the ortho-long chain, originating four atropisomers $(\alpha \alpha \alpha \alpha, \alpha \alpha \alpha \beta, \alpha \beta \alpha$, $\alpha \alpha \beta \beta$ ) with distinct environments, depending on the solvent polarity. The studies showed that the best catalytic results in cyclohexane hydroxylation, using iodosylbenzene (PhIO) as oxygen donor, were obtained in the presence of the more polar atropisomers $(\alpha \alpha \alpha, \alpha \alpha \alpha \beta)$.

The catalytic activity under homogeneous conditions is frequently limited by catalyst solubility. The effect of the solvent and ultrasonic agitation on catalytic performance was also studied by Iamamoto et al. ${ }^{58}$ using neutral and cationic iron(III) porphyrins.

Metalloporphyrins are also considered efficient catalysts for alkene oxidation. In this reaction it is expected that the products formed result from competition between the oxidation of the alkene groups $\mathrm{C}=\mathrm{C}$ (epoxide) and the allylic $\mathrm{C}-\mathrm{H}$ groups (alcohol and ketone). The formation of allylic products is also favored by the presence of oxygen, ${ }^{59}$ as observed using monosubstituted manganese(III) porphyrins (Figure 5). The allylic product yields were consistent with the presence of dioxygen (above 100\%) and the epoxide selectivity was reached under nitrogen 


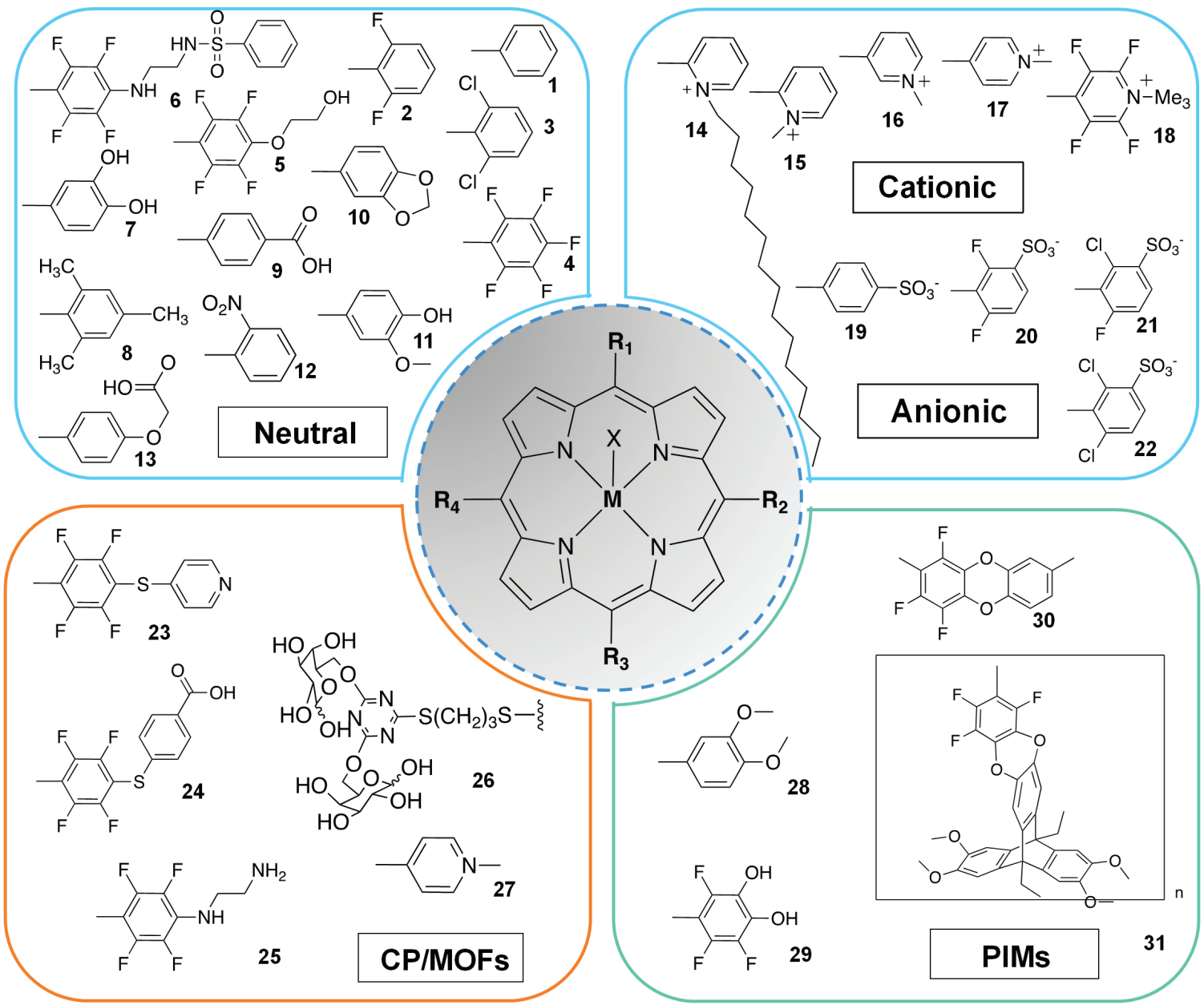

Figure 4. General schematic representation of some meso-substituted porphyrin ligands present in different metalloporphyrins cited in this work; $\left[\mathrm{R}_{1-4}=\right.$ meso substituents; $\mathrm{M}=$ metal(III) ion; $\mathrm{X}=$ counter ion; $\mathrm{CP}=$ coordination polymers; $\mathrm{MOF}$ = metal-organic frameworks and $\mathrm{PIMs}=$ polymers of intrinsic microporosity).

atmosphere for 5-(2-(3-bromo-1-propoxy)phenyl)10,15,20-tritolylporphyrinmanganese(III) acetate ([MnM2-BrPTTP]Ac). On the other hand, the presence of -OH substituent favored the formation of allylic oxidation products, including under nitrogen atmosphere.

It is well established that the presence of electronegative or bulky substituents in the porphyrin ring can increase the lifetime and reactivity of the catalytically active species in

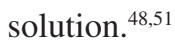

In fact, metalloporphyrins with electronegative or bulky groups in meso-aryl substituents, the so-called second-generation porphyrin catalysts, show much better performance than the first-generation typically represented by meso-tetraphenylporphyrin, abbreviated as TPP (Figure 4, R = 1), and more frequently than the third-generation ones (second-generation catalysts with electronegative substituents at the $\beta$-positions). ${ }^{48,51}$

The performance of the typical second-generation catalyst 5,10,15,20-tetrakis(pentafluorophenyl) porphyrinate)iron(III) ([Fe(TPFPP) $] \mathrm{Cl})$ (Figure 4,
$\mathrm{R}=4$ ) for cyclohexane hydroxylation was investigated by different groups. ${ }^{27,54,60-66}$ In these studies, it was reported that the yields are dependent on the type of oxidant and solvent used in the catalytic reaction. For example, studies performed by Iamamoto et al..$^{58}$ showed that competitive oxidation reactions between $\mathrm{PhIO}$-dichloromethane and PhIO-cyclohexane by the catalytic active species diminished the desired oxidation product yield. Acetonitrile can minimize these competitive reactions in some cases. ${ }^{60}$

The third generation of metalloporphyrins (porphyrin ring structures presenting substituents, mainly halogens atoms, at the $\beta$-pyrrolic position-as exemplified in Figure 6$)^{48,51}$ have been less explored as oxidation reaction catalysts, since the preparation of this family of macrocyclic ligands and the instability of the resulting metallocomplexes limited their uses. ${ }^{67-70}$ In spite of this, Idemori's research group presented an interesting contribution to the state of art with the results obtained in cyclohexane oxidation using a series of third-generation manganese(III) porphyrins as 


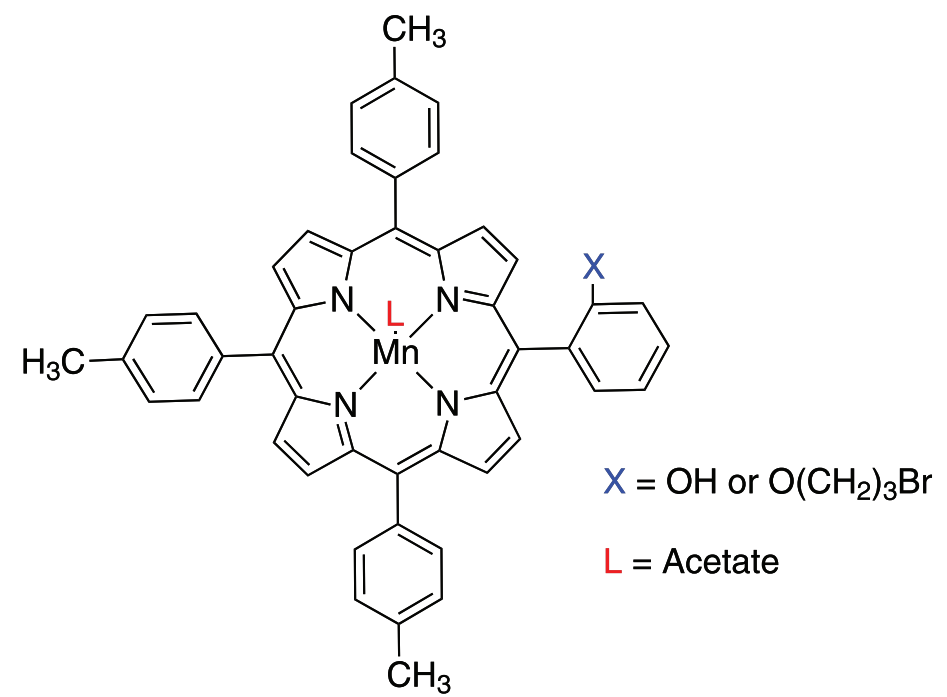

Figure 5. Schematic representation of the non-symmetrical manganese(III) porphyrins $\left[\mathrm{Mn}\left(\mathrm{M}_{2-\mathrm{OH}} \mathrm{PTTP}\right)\right] \mathrm{Ac}$ and $\left[\mathrm{Mn}\left(\mathrm{M}_{2-\mathrm{Br}} \mathrm{PTTP}\right)\right] \mathrm{Ac}$.

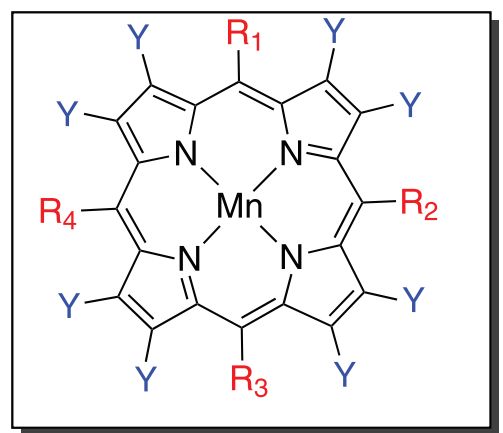

$$
\begin{array}{ll}
\text { MnP1 } & \mathrm{R}_{1}=\mathrm{R}_{2}=\mathrm{R}_{3}=\mathrm{R}_{4}=\mathrm{Ph} ; \mathrm{Y}=\mathrm{H} \\
\text { MnP2 } & \mathrm{R}_{1}=p-\mathrm{Ph}-\mathrm{NO}_{2} ; \mathrm{R}_{2}=\mathrm{R}_{3}=\mathrm{R}_{4}=\mathrm{Ph} ; \mathrm{Y}=\mathrm{H} \\
\text { MnP3 } & \mathrm{R}_{1}=p-\mathrm{Ph}-\mathrm{NO}_{2} ; \mathrm{R}_{2}=\mathrm{R}_{3}=\mathrm{R}_{4}=\mathrm{Ph} ; \mathrm{Y}=\mathrm{Br} \\
\text { MnP4 } \mathrm{R}_{1}=\mathrm{R}_{2}=p-\mathrm{Ph}-\mathrm{NO}_{2} ; \mathrm{R}_{3}=\mathrm{R}_{4}=\mathrm{Ph} ; \mathrm{Y}=\mathrm{H} \\
\text { MnP5 } \mathrm{R}_{1}=\mathrm{R}_{3}=p-\mathrm{Ph}-\mathrm{NO}_{2} ; \mathrm{R}_{3}=\mathrm{R}_{4}=\mathrm{Ph} ; \mathrm{Y}=\mathrm{H} \\
\text { MnP6 } \mathrm{R}_{1}=\mathrm{R}_{2}=p-\mathrm{Ph}-\mathrm{NO}_{2} ; \mathrm{R}_{3}=\mathrm{R}_{4}=\mathrm{Ph} ; \mathrm{Y}=\mathrm{Br} \\
\text { MnP7 } \mathrm{R}_{1}=\mathrm{R}_{3}=p-\mathrm{Ph}-\mathrm{NO}_{2} ; \mathrm{R}_{3}=\mathrm{R}_{4}=\mathrm{Ph} ; \mathrm{Y}=\mathrm{Br} \\
\text { MnP8 } \mathrm{R}_{1}=\mathrm{R}_{2}=\mathrm{R}_{3}=\mathrm{R}_{4}=\mathrm{Ph}-3 \mathrm{Br}, 4 \mathrm{OMe} ; \mathrm{Y}=\mathrm{H} \\
\text { MnP9 } \mathrm{R}_{1}=\mathrm{R}_{2}=\mathrm{R}_{3}=\mathrm{R}_{4}=\mathrm{Ph}-3 \mathrm{Br}, 4 \mathrm{OMe} ; \mathrm{Y}=\mathrm{Br}
\end{array}
$$

Figure 6. Schematic representation of manganese(III) porphyrins of different generations.

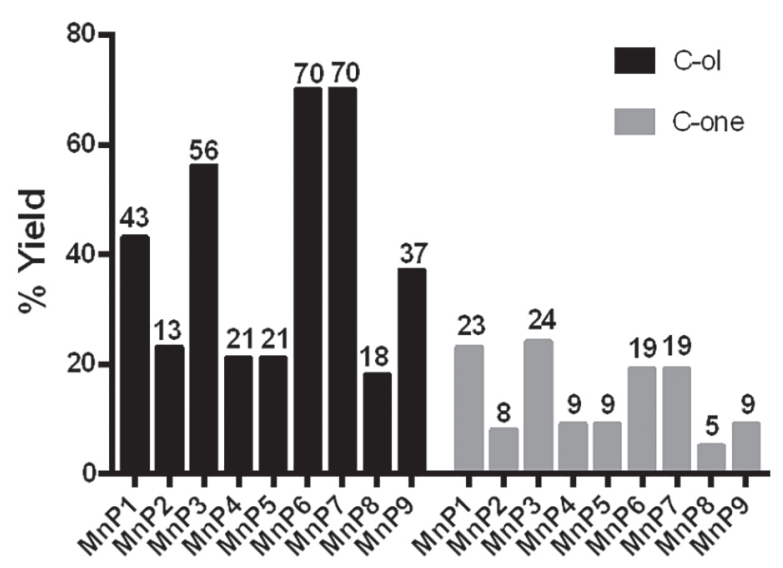

Figure 7. Product yields obtained during the oxidation of cyclohexane by manganese porphyrins $(\mathrm{MnP})$ from Figure 6 using $\mathrm{PhIO}$ as oxidant under homogeneous conditions.

catalysts (for example, Figure 6) and iodosylarenes as oxidant (Figure 7). ${ }^{67,71}$

The set of results using third-generation of catalysts (MnP3, MnP6, MnP7 and MnP9) showed good catalytic efficiency and selectivity for the formation of alcohol in all the cases similar to that observed for the first (MnP1) and second-generation catalysts $(\mathrm{MnP} 2, \mathrm{MnP} 4, \mathrm{MnP} 5$ and MnP8) (Figure 7). On the other hand, the catalyst MnP6 (two nitro groups) was more efficient than the parent MnP3 (one nitro group) and the non-substituted complex in the $\beta$-positions (MnP4). The authors did not observe differences of reactivity with the catalysts bearing the nitro substituents in adjacent ( $c i s$ ) and opposite (trans) positions. An opposite result was reported by Castro et al. ${ }^{65}$ when manganese(III) porphyrins bearing two ethylene glycol moieties were used as catalysts, attributed to the stability of the complexes (see section 3).

The study also showed an improvement of MnP9 catalytic performance by the addition of imidazole as cocatalyst. This efficiency was strongly improved (ca. 66\% versus $46 \%$ with or without additive using $\mathrm{PhIO}$ as oxidant) when the reaction was accomplished in the presence of imidazole and $\mathrm{PhI}(\mathrm{OAc})_{2}$ as oxidant, being more efficient than its second-generation counterpart. The same behavior was observed for adamantane and $n$-hexane oxidation. For example, using adamantane as substrate the yields for 1-adamantanol (1-Adol) and 2-adamantanol (2-Adol) varied between 19 and $46 \%$ depending on the reaction 
conditions. Regioselectivity for 1-adamantanol was observed for both MnP8 and MnP9. This regioselectivity was dependent on the substituents of the porphyrin ring, and the change of the substituents of the meso positions to 2-bromo-1,3-dimethoxycyclohexane ${ }^{68}$ resulted in the increase of 2-Adol yield (2\% for 1-Adol and $14 \%$ for 2-Adol) when the reactions were performed in similar conditions to MnP9 (39\% for 1-Adol and 2\% for 2-Adol).

Also using third-generation catalysts, da Silva et al. ${ }^{67}$ performed oxidation reactions in the presence of water and $\mathrm{PhI}(\mathrm{OAc})_{2}$ to generate $\mathrm{PhIO}$ in situ. In general, addition of water led to increased total yield and decreased catalyst bleaching. In this case, the water acted as axial ligand, along with imidazole. The introduction of bromine atoms at the $\beta$-pyrrolic positions of MnP9 can fine-tune the catalytic efficiency, selectivity and regioselectivity. ${ }^{67}$

Martins et $a l .^{72}$ reported the lupeol oxidation catalyzed by three manganese(III) porphyrins of different generations: first generation [Mn(TPP)], second generation $\mathrm{Mn}^{\mathrm{III}}$ complex of meso-tetrakis(4-carbomethoxyphenyl) porphyrin, [Mn(TCMPP)] (Figure 4, R = 11), and third generation $\mathrm{Mn}^{\mathrm{III}}$ complex of $\beta$-octabromo-meso-tetrakis (4-carbomethoxyphenyl)porphyrin, ([MnBr 8 (TCMPP)]), under homogeneous conditions, which yielded 3ß,30-dihydroxylup-20(29)-ene (L1) or 20-oxo-33-hydroxy29-norlupeol (L2). In this study, it was observed that [Mn(TPP) and [Mn(TCMPP)] provided L1 with yields of 6 and $14 \%$, respectively, while the formation of L2 (6\% yield) was observed for $\left[\mathrm{MnBr}_{8}(\mathrm{TCMBPP})\right]$. This was the first example of a selective oxidative cleavage of the $\mathrm{C}=\mathrm{C}$ bond of lupane catalyzed by metalloporphyrins and a good result with a third-generation porphyrin catalyst.

\section{Immobilization of Metalloporphyrins for Heterogeneous Catalysis}

In recent decades, the scientific reports considering the use of a wide range of metalloporphyrins (different ligands and coordination metal ions) as homogeneous catalysts have shown they are efficient and selective catalysts in oxidation reactions of organic substrates. . $5,26,47,48,66,73,74^{-1}$ However, these same reports also show that depending on the metalloporphyrin, these systems have some drawbacks that hinder the perspective of idealizing their use as catalysts in future industrial processes. ${ }^{75}$ The main problems associated with these limitations are poor solubility and the possible bimolecular interactions that can occur in solution, possibly leading to inactive species (e.g., formation of dimeric species or self-destructive oxidation). ${ }^{25,48,76}$

Besides that, for industrial uses of these versatile catalyst systems, their reusability for several catalytic cycles is also desirable. This is an important aspect, considering the hard synthetic conditions usually required ${ }^{77}$ and the cost of the procedure (for example, $10 \mathrm{~g}$ of a first-generation porphyrin $\left[\mathrm{H}_{2}(\mathrm{TPP})\right]$, a poor catalyst when metallated, can cost about 79 Euros, and $1 \mathrm{~g}$ of the second-generation $\left[\mathrm{H}_{2}\right.$ (TPFPP) $]$ can cost 146 Euros). ${ }^{78}$

To overcome these drawbacks, one of the alternatives that has been intensively explored by us and others in Brazil and abroad is to prepare insoluble catalytic solids based on metalloporphyrins through different strategies: (i) immobilization of the catalytic species in organic or inorganic matrices (Table 1); (ii) preparation of insoluble solids by MP heterogenization via a metalorganic frameworks (MOF) structure (metal organic framework), ${ }^{80,140-146}$ or via a microporous polymer network (e.g., POM = porous organic polymers, $\mathrm{COF}=$ covalent organic framework) ${ }^{147-156}$ or by preparing polymeric organic-inorganic hybrid materials containing a MP in their structures (e.g., porphyrinic silica solids) (Figure 4). ${ }^{71,157-162}$

These two main strategies ( $i$ and $i i$ ) frequently prevent MP self-destruction and in most cases facilitate the recovery and reuse of the catalyst. In addition to those advantages, solid catalysts based on MPs can promote more rational use of the catalytic species, because small amounts of MPs (in comparison to its use in solution) can be efficiently used as a catalyst.

In this sense, in the past 30 years chemists who work with porphyrins as catalysts in Brazil have made many contributions to the advancement of knowledge in this area, and in many cases they were pioneers in the use of solids like zeolites, ${ }^{99}$ porous glass, ${ }^{102}$ layered synthetic solids, ${ }^{114,115,121,122,124}$ and natural clays ${ }^{107,108}$ to immobilize MP and to prepare structured solids composed of MPs, like porphyrinosilicas. ${ }^{157-163}$

Table 1 presents various supports that have been investigated to immobilize metalloporphyrins to develop new catalysts.

Among the supports that can be used to immobilize MPs and many other catalytic species, silica stands out due to its thermal and mechanical stability and chemical inertness under catalytic oxidation conditions. ${ }^{163}$ Besides that, silica contains reactive silanol groups ( $\mathrm{Si}-\mathrm{OH})$, which can undergo extra functionalization. For instance, reactions with 3-aminopropyltriethoxysilane (3-APTS) or imidazol chloropropyl silane (IPG) provide silica with adequate functional groups to graft different molecules, including MPs. ${ }^{80,164,165}$

The immobilization process of MP in silica can be achieved by different ways, such as: (i) encapsulation inside the silica matrix by the sol-gel method; ${ }^{80,81,166}($ ii) superficial 
Table 1. Solids used as support for immobilization of different metalloporphyrins for different purposes, mainly catalysis, in Brazil

\begin{tabular}{|c|c|c|}
\hline Solid support & Detail & Reference \\
\hline \multirow{5}{*}{ Silica } & commercial & 79 \\
\hline & amorphous silica prepared by sol-gel process & $76,80-84$ \\
\hline & mesoporous silica (SBA-15, HMS, MCM-41) & $85-91$ \\
\hline & magnetic $\left(\mathrm{F}_{3} \mathrm{O}_{4}\right)$ mesoporous or amorphous silicas & $86,87,92-94$ \\
\hline & modified amorphous or mesoporous silica functionalization & $61,64,79,85-87,95-98$ \\
\hline Zeolite & $\mathrm{NaY}$ & $99-101$ \\
\hline Porous glass & PVG (porous Vycor glass) & 102 \\
\hline \multirow{6}{*}{ Natural solids (clays) } & montmorillonite clay & 103 \\
\hline & kaolinite clay & $104-106$ \\
\hline & halloysite & 107,108 \\
\hline & chrysotile & 109 \\
\hline & $\begin{array}{c}\text { modified natural clay (by exfoliation, intercalation/delamination, delamination, acid } \\
\text { treatment, functionalization, etc.) }\end{array}$ & $64,105,106,110-112$ \\
\hline & talc-aminofunctionalyzed phyllosilicates & 113 \\
\hline \multirow{6}{*}{ Synthetic layered solids } & layered $\mathrm{MoS}_{2}$ & 114 \\
\hline & layered double hydroxides (LDH) & $60,115-120$ \\
\hline & layered hydroxide salts (LHS) & 121,122 \\
\hline & layered hydroxides $+\mathrm{TiO}_{2}$ & 123 \\
\hline & lithium gordaite (layered hydroxide salt with cation exchange capacity) & 124 \\
\hline & $\begin{array}{l}\text { modified synthetic layered solid (by exfoliation, temperature treatment, } \\
\text { functionalization, preparation of macroporous layered solids, etc.) }\end{array}$ & $117,118,119,125-129$ \\
\hline Alumina & commercial & 130 \\
\hline Aluminosilicate & solid obtained by sol-gel process & 131 \\
\hline \multirow{2}{*}{$\mathrm{ZnO}$} & nanostructures & 132 \\
\hline & prepared by in situ thermal decomposition of LHS & 133 \\
\hline $\mathrm{TiO}_{2}$ & polycrystalline anatase phase & 134 \\
\hline Carbon nanotubes & multi-wall carbon nanotubes (MWCNT) & $135-137$ \\
\hline Polymeric membranes & polymeric film based on poly(dimethylsiloxane) (PDMS) & 138 \\
\hline Chitosan & film & 139 \\
\hline
\end{tabular}

electrostatic interaction; ${ }^{76,79,167-169}$ and (iii) covalent bonding, when the silica is previously functionalized. ${ }^{158,164,165,168,170,171}$

In 1992, Mansuy and co-workers ${ }^{74}$ published one of the first works reporting the use of second- and third-generation MPs anchored on modified silica as catalysts. They immobilized three second-generation metalloporphyrins ([Fe(TPFPP)], [Mn(TPFPP)] (Figure 4, R = 4) and 5,10,15,20-tetrakis( pentachlorophenyl)porphyrinate)iron(III) [Fe(TPClPP)] (analogue to Figure 4, $\mathrm{R}=\mathbf{4}$, but with $\mathrm{Cl}$ substituents instead of $\mathrm{F})$, and an analogous third-generation [Fe( $\left.\left.\mathrm{Br}_{8} \mathrm{TPFPP}\right)\right]$ (bearing eight bromine atoms at the $\beta$-pyrrolic positions of the macrocycle, presented in Figure $4, \mathrm{R}=4$ ) on silica modified by 3-APTS (3-aminopropyltrietoxisilane). The grafting was performed by nuclear substitution of the parahalogen atoms of the aryl substituents with the silica amino groups. All the solids were able to successfully epoxidize
(Z)-cyclooctene, with yields ranging from 80 to $100 \%$. The authors also described that these supported MPs in the oxidation of cyclohexane and heptane showed higher selectivity for alcohol than for the ketone products. In all cases, the fluorinated second-generation MPs displayed the best catalytic activity. Unfortunately, no recyclability results were mentioned for the prepared solids.

As mentioned before, Brazilian researchers have made important contributions regarding the use of amorphous silica for the preparation catalyst materials for oxidation reactions (Table 1). This can be explained by considering the facility of immobilizing cationic metalloporphyrins on commercial silica, the easy preparation of the silica solid by hydrolytic sol-gel processes, and the easy and not very expensive functionalization of this solid, allowing the immobilization of efficient metalloporphyrins of the second generation. ${ }^{48}$ 
In 1995 Iamamoto et al. ${ }^{79}$ reported the first immobilization of cationic ortho and para-alkylpyridyl substituted iron porphyrins (Figure 4, R = $\mathbf{1 5}$ and $\mathbf{1 7}$, respectively) on silica gel (commercial) and modified by using imidazole and 3-chloropropyl trimethoxysilane, resulting in the solid popularly named silica-IPG. The catalytic activity of these cationic iron(III) porphyrins under homogeneous conditions was limited by their solubility. For instance, the oxidation of cyclohexane in dichloromethane (a good solvent for the substrate) yielded about $1 \%$ cyclohexanol. However, using FeP immobilized on silica or silica-IPG, the yields increased to about 30 to $50 \%$ in the same solvent. Besides that, the oxidative studies showed that all the solids could be recycled.

After this first communication, many other metalloporphyrins were immobilized on commercial silica or silica modified chemically by different silanes for efficient and selective oxidation of alkanes, ${ }^{61,64,80,98,165}$ alkenes, ${ }^{61,64,80,165}$ dyes, ${ }^{92}$ pesticides, ${ }^{90}$ among others. ${ }^{164}$

The sol-gel process is a powerful tool to synthesize supported catalytic materials, since it is possible to control catalyst composition and morphology as well as textural properties. Using this process, amorphous silica was prepared by the hydrolytic sol-gel process and used as support for metalloporphyrin catalytic species. ${ }^{76,80-84}$

A class of hybrid organic-inorganic materials, metalloporphyrinosilica (MPS), was prepared by a sol-gel process, where the functionalized MP building blocks "were assembled into a three-dimensional silicate network". The hybrid material MPS $\left(\mathrm{M}=\mathrm{Fe}^{3+}\right.$ or $\left.\mathrm{Mn}^{3+}\right)$ was produced, where the $\mathrm{M}$ is coordinated to $N$-substituted nitrogen bases of porphyrin. MPs can act as template molecules, creating a polymeric substance containing specific binding sites as receptors in enzyme models (MPS-template). In general, high yields in epoxidation were observed with MPS-template, as expected for the cytochrome P-450 model. The MPS-template showed the advantage that no MP leached from matrix and it mimicked the "active site isolation principle" of naturally occurring enzymes, like cytochrome P-450, leading to shape- and regioselective catalysts. ${ }^{157-163}$

It is well known that the main disadvantage of catalysts based on immobilized metalloporphyrins is the decrease in the reaction yield compared with non-immobilized metalloporphyrins, since the diffusion of the reactants to the catalytically active center can be hindered by the support. ${ }^{172-175}$ In general, the selectivity observed in homogeneous catalysis is reproduced in the heterogeneous situation, and reports are rare of different selectivity results after immobilizing MPs in any support. The studies showed that if a MP in homogeneous catalysis has no solubility problems, especially when using charged porphyrins (cationic or anionic), the catalytic results of the reaction using a metalloporphyrin in solution or after being immobilized in silica supports ${ }^{95}$ tend to be similar in terms of selectivity, and no synergistic effect caused by the support is observed. However, for other solid supports the situation can be different.

For instance, we observed that depending on the support for MP heterogenization or the MP solid catalyst used (MOF, PIM, etc.), some unusual results occurred concerning their efficiency and also their selectivity compared to the results obtained with the same MP under homogeneous conditions. This type of behavior was observed, for example, when three different anionic iron porphyrins were immobilized on layered hydroxide salts. ${ }^{121}$

Layered materials are an interesting alternative class of solids for use as inorganic supports for catalytic compounds. These types of materials occur in nature (e.g., natural clays $)^{64,103-111,113,167,168,176}$ or can be prepared, yielding layered double hydroxides (LDH) ${ }^{60,115-120,125-129,177}$ or just layered hydroxide salts (LHS). ${ }^{121-123}$ These compounds are robust, relatively inexpensive, easy to produce and use as supports, mainly for charged catalytic species.

In particular, layered hydroxide salts (LHS) consist of positively charged layers separated by exchangeable anions. They have been considered promising support materials for catalytic species. ${ }^{178}$ The basic structure of layered hydroxide salts is based on the layers of modified brucite $\left(\mathrm{Mg}(\mathrm{OH})_{2}\right)$, a natural solid that is formed by a hexagonal packet of hydroxyl ions, where the octahedral sites are occupied by $\mathrm{a} \mathrm{Mg}^{2+}$ center surrounded by hydroxyl groups. This natural compound has a basal distance of $4.8 \AA$ in a neutral layered structure. ${ }^{12,179} \mathrm{New}$ compounds were prepared inspired in the Brucite structure, by idealizing the replacement of the structural $\mathrm{Mg}^{2+}$ by other ions, such as $\mathrm{Zn}^{2+}, \mathrm{Co}^{2+}$ or $\mathrm{Cu}^{2+}$ (with different coordination numbers), while the hydroxyl groups can be substituted by other species, like water or nitrate. The modifications originated the class of layered hydroxide salts, which consist of an alternate sequence of charged brucite-like layers and intercalated anions. ${ }^{180}$

For the specific structure of hydrated zinc hydroxide nitrate $\left(\mathrm{ZHN}-\mathrm{Zn}_{5}(\mathrm{OH})_{8}\left(\mathrm{NO}_{3}\right)_{2} \cdot 2 \mathrm{H}_{2} \mathrm{O}\right)$, the layers are formed by octahedral zinc sites coordinated by hydroxide anions at the vertices in which one-fourth of the sites are vacant; while zinc atoms coordinated in tetrahedral geometry are located on the upper and lower sides of the octahedra. Three vertices of the tetrahedral zinc are occupied by hydroxide anions from the octahedral sheet, whereas the fourth apical vertex contains a water molecule. The nitrate ions are located between the layers of ZHN and are not coordinated to the metal. So, in this case, ZHN can be considered an 
anionic exchanger layered solid. The basal spacing of this kind of solid is approximately $9.9 \AA$ (Figure 8 ). ${ }^{121,178}$ On the other hand, zinc hydroxide chloride (ZHC) or Simonkolleite is considered a non-exchangeable layered hydroxide salt (LHS), different from ZHN. In ZHC, the chloride anions are grafted directly to the layers and the compound is neutral. ${ }^{178}$ Specifically, Simonkolleite is represented by the formula $\mathrm{Zn}_{5}(\mathrm{OH})_{8} \mathrm{Cl}_{2} \cdot \mathrm{H}_{2} \mathrm{O}^{181,182}$ and the basic structural unit contains a vacancy in a quarter of the octahedral zinc sites coordinated to hydroxide anions, while the upper and lower sides of this void contain tetrahedral zinc sites, originating a positive layer charge. ${ }^{178}$ In the tetrahedral zinc site, three vertices are occupied by hydroxide anions from the octahedral sheet, and in the fourth position the metal is coordinated to the chloride anions, building a neutral layered structure. In the Simonkolleite structure, water molecules are also present between the layers, ${ }^{182}$ generating a solid with basal distance of approximately $7.8 \AA{ }^{181}$ These subtle differences between the two layered solids (ZHC and ZHN) from the same support family (LHS) resulted, after the immobilization of the same anionic metalloporphyrin family (Figure 4, R = 20, 21, 22), in solid catalysts that presented completely different catalytic behaviors in oxidation reactions. ${ }^{121,122}$

Machado et al. ${ }^{121,122}$ reported that after being immobilized in ZHC and ZHN, three different anionic metalloporphyrins (Figure $4, \mathrm{R}=\mathbf{2 0}, \mathbf{2 1}, \mathbf{2 2}$ ) presented unusual catalytic results regarding the selectivity to alcohol and ketone in the oxidation of cyclohexane. This was the first case showing a change of selectivity for different products of the same catalytic reaction caused by the support, where the catalytic species was immobilized. In the case of the catalytic species 5,10,15,20-tetrakis(2,6-dichloro-3-sulfonatophenyl) porphyrinate)iron(III) [Fe(TDCSPP)] (Figure $4, \mathrm{R}=\mathbf{2 2}$ ) immobilized in ZHC (a solid called FeDC-ZHC), the alcohol yield observed in the heterogeneous catalysis was higher than the ketone yield (cyclohexanol about 23\% and cyclohexanone about $2 \%$, alcohol $/$ ketone ratio $=11$ ). These results are similar to those from the homogeneous catalysis with respect to the selectivity to the alcohol product (cyclohexanol 18\% and cyclohexanone 4\%, alcohol/ketone yield ratio $=5) .{ }^{122}$

On the other hand, when the same catalyst was immobilized on the ZHN solid (solid called FeDC-ZHN), higher ketone than alcohol yields were observed (cyclohexanol about 2\% and cyclohexanone about 70\%, alcohol/ketone ratio 0.03 ), unlike the homogeneous ones with the same anionic MP (cyclohexanol about $31 \%$ and cyclohexanone about $5 \%$, alcohol/ketone ratio 6). ${ }^{115}$

Interestingly, when the substrate used in the oxidation reaction was a linear alkane (heptane), the selectivity for alcohol instead of ketone was the same for both classes of catalyst (MP/ZHC or MP/ZHN), suggesting that the solid supports and their subtle structural differences might exert a steric constraint on the MP catalyst and substrate, causing a change in the selectivity for the alcohol in one case (ZHC) or ketone in another (ZHN) when the alkane was cyclic. This steric imposition did not appear to be important when the alkane used was linear.

Instead of differences in the selectivity results of using one or the other hydroxide salt solid support, all the prepared catalysts showed high capacity for reuse.

This unusual catalytic result presented by the same MP immobilized on the two different members of the LHS family was one of the first catalytic reports showing the importance of the choice of the support for achieving a different catalytic result.

Clay minerals are also usually used as supports for metalloporphyrin immobilization, ${ }^{64,103-111,113,167,168,176}$ but in general they have only been used to immobilize a single metalloporphyrin. Recently, Machado et al. ${ }^{107}$ reported the simultaneous immobilization of two distinct
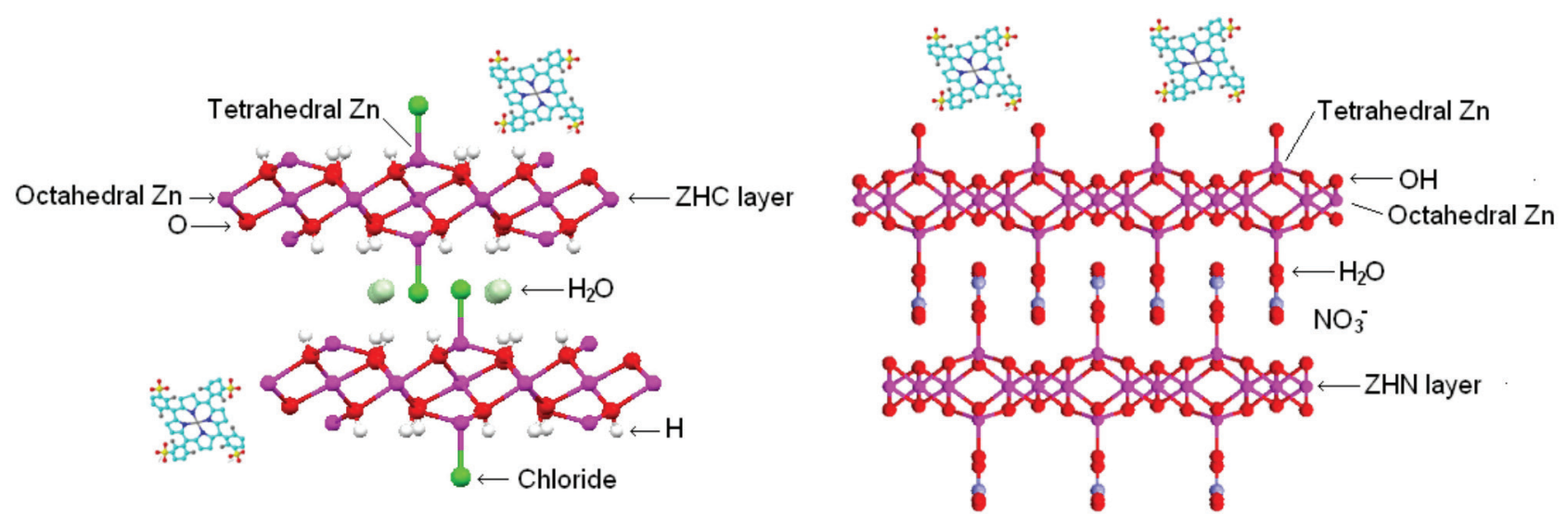

Figure 8. Schematic representation of the layered solids ZHC-zinc hydroxide chloride (left) and ZHN-zinc hydroxide nitrate (right). 
metalloporphyrins in the same clay mineral: raw halloysite. This work was carried out to investigate whether it was possible immobilize two MPs with opposite charges in this support, and if so, what would be the effect (synergistic, antagonist, etc.) of the two catalysts in the same solid.

Halloysite is a clay mineral belonging to the kaolin group. It consists of halloysite $10.0 \AA$, which has the composition $\mathrm{Al}_{2} \mathrm{Si}_{2} \mathrm{O}_{5}(\mathrm{OH})_{4} \cdot 2 \mathrm{H}_{2} \mathrm{O}$, and the polymorphs halloysite $7.0 \AA$, besides others, which are all composed of $\mathrm{Al}_{2} \mathrm{Si}_{2} \mathrm{O}_{5}(\mathrm{OH})_{4}{ }^{183}$ Halloysite polymorphs exist as nanoscrolls, although other morphologies have also been reported. ${ }^{184}$ Upon heating to temperatures above $50{ }^{\circ} \mathrm{C}$, halloysite $10.0 \AA$ can be irreversibly converted to halloysite $7.0 \AA{ }^{185}$ Halloysite nanoscrolls contain positive and negative residual charges on their edges, whereas their surface displays negative residual charges, ${ }^{108}$ making them good candidates for the immobilization of charged species like MPs. ${ }^{107}$

Machado et al. ${ }^{107}$ observed that it is possible to immobilize two porphyrins with opposite charges in solid halloysite, and the resulting solid (named by the authors FeMn-Hallo) contained both MPs immobilized on halloysite $7.0 \AA$ (the cationic MnP, Figure 4, R = 17, and the anionic FeP, Figure 4, R = 20) and was able to oxidize cyclohexane to cyclohexanol and cyclohexanone (alcohol yield $31 \%$ and ketone yield $8 \%$ ). Indeed, FeMn-Hallo affords improved yields in comparison to the sum of the product yields obtained in the catalytic reaction using as catalyst the solids resulting from only one MP immobilized (Fe-Hallo-alcohol yield $16 \%$ and ketone yield $5 \%$ and Mn-Hallo-alcohol yield 5\% and ketone yield 2\%), or when a physical mixture of the solids Fe-Hallo or Mn-Hallo was used as catalyst (Fe-Hallo + Mn-Hallo, alcohol yield $9 \%$ and ketone yield $2 \%$ ), suggesting for the first time a synergistic effect of both MP catalysts immobilized in the same solid support.

The combination of the catalytic properties of MPs immobilized on layered solids and titanium-based supports generates great interest in the context of using the resulting material in photocatalysis. ${ }^{186,187}$ In spite of the controversy in the literature about the preparation of layered compounds like layered double hydroxide containing $\mathrm{Ti}^{\mathrm{IV}}$, ${ }^{188-190}$ recently Mantovani et al. ${ }^{123}$ described the preparation of new solids based on layered solids containing titanium oxide. The authors applied the usual method to produce LDH-the urea hydrolysis method- ${ }^{191}$ and studied the use as support for the immobilization of MPs in order to investigate the possible application of the resulting solids in catalysis and catalytic oxidation reactions assisted by light. By the urea hydrolysis method, the authors prepared the solid hydrozincite (a layered zinc hydroxide carbonate salt) containing $\mathrm{TiO}_{2}$ segregated in the layered structure (called solid C).

The solid $\mathrm{C}$ was efficient to immobilize anionic species (in the hydrozincite part of the solid) and cationic species (in the $\mathrm{TiO}_{2}$ part). Thus, the solid was used for the immobilization of one cationic $\mathrm{FeP}\left(\left[\mathrm{Fe}\left(\mathrm{T}_{4} \mathrm{MPyP}\right)\right]\right.$, Figure $4, \mathrm{R}=\mathbf{1 7}$ ), one anionic $\mathrm{MnP}$ ([Mn(TDFSPP)], Figure $4, \mathrm{R}=\mathbf{2 0}$ ) and both ionic metalloporphyrins. ${ }^{123}$ In spite of the low MP loading in all the solids prepared (about $10^{-6} \mathrm{~mol}$ of MP per $1 \mathrm{~g}$ of solid support), all the three solids (named FeP-C, MnP-C and FeP-MnP-C) were more efficient than the non-immobilized metalloporphyrins when they were used as catalysts in the oxidation of cyclohexane under dark conditions. These results were attributed to the poor solubility of both MPs in the dichloromethane/ acetonitrile mixture $(1: 1, \mathrm{v} / \mathrm{v})$ used as solvent in the reaction (Table 2). The reaction assisted by light using the solid

Table 2. Results of the cyclohexane oxidation using different catalysts without light and assisted by the artificial radiation (exposure to a $125 \mathrm{~W}$ mercury vapor lamp with Hg-Quartz bulb) ${ }^{\text {a }} 23$

\begin{tabular}{|c|c|c|c|c|c|c|c|c|}
\hline \multirow[t]{2}{*}{ Catalyst } & \multicolumn{2}{|c|}{ Yield (darkness) } & \multirow{2}{*}{$\begin{array}{c}\mathrm{A}+\mathrm{K}^{\mathrm{a}} \\
\text { total yield / \% }\end{array}$} & \multirow[t]{2}{*}{$\mathrm{A} / \mathrm{K}$ ratio } & \multicolumn{2}{|c|}{$\begin{array}{c}\text { Yield (assisted by artificial } \\
\text { radiation) }{ }^{\mathrm{c}, \mathrm{d}} / \%\end{array}$} & \multirow{2}{*}{$\begin{array}{c}\mathrm{A}+\mathrm{K} \\
\text { total yield / \% }\end{array}$} & \multirow[t]{2}{*}{$\mathrm{A} / \mathrm{K}$ ratio } \\
\hline & $\mathrm{A}$ & $\mathrm{K}$ & & & $\mathrm{A}$ & $\mathrm{K}$ & & \\
\hline $\mathrm{MnP}^{\mathrm{b}}$ & 14.2 & 2.84 & 17.0 & 5.0 & 4.21 & 3.80 & 8.01 & 1.1 \\
\hline $\mathrm{FeP}^{\mathrm{b}}$ & 3.00 & 1.00 & 4.00 & 3.0 & 8.10 & 5.90 & 14.0 & 1.4 \\
\hline $\mathrm{MnP}-\mathrm{C}$ & 18.3 & 2.33 & 20.6 & 7.8 & 50.3 & 13.8 & 64.1 & 3.6 \\
\hline $\mathrm{FeP}-\mathrm{C}$ & 14.9 & 0.53 & 15.4 & 26 & 25.4 & 17.6 & 43.0 & 1.5 \\
\hline FeP-MnP-C & 20.0 & 0.93 & 20.9 & 21 & 80.2 & 19.7 & 100 & 4.1 \\
\hline $\mathrm{C}^{\mathrm{e}}$ & 1.19 & 0.95 & 2.14 & 1.2 & 20.8 & 17.4 & 38.2 & 1.2 \\
\hline $\mathrm{PhIO}^{\mathrm{e}}$ & - & - & - & - & 28.9 & 17.8 & 46.7 & 1.6 \\
\hline
\end{tabular}

aReaction conditions: ${ }^{123}$ catalyst/oxidant/cyclohexane molar ratio of 1:50:5000. The reactions were carried out in a dichloromethane/acetonitrile mixture $(1: 1, \mathrm{v} / \mathrm{v})$ at room temperature for $1 \mathrm{~h}$. Homogeneous and heterogeneous catalysis reactions were performed using the same experimental conditions; ${ }^{b}$ homogeneous phase catalysis using FeP and MnP as catalysts; ' $y$ yields based on the amount of PhIO used in the reaction as oxidant; ${ }^{\mathrm{A}} \mathrm{A}=\mathrm{cyclohexanol}$ and $\mathrm{K}=$ cyclohexanone; ${ }^{\mathrm{e}}$ control reactions in the absence of catalyst MP: $\mathrm{C}=$ solid $\mathrm{C}+$ substrate $+\mathrm{PhIO}$ and $\mathrm{PhIO}=$ substrate $+\mathrm{PhIO}$. 
MnP-C and FeP-C presented better results in comparison with those without light, showing some effect caused by the support/light, since only the free MP presented poor catalytic results under the same conditions.

An amazing result with this family of solid catalysts was observed when the solid FeP-MnP-C was used as catalyst in reactions assisted by light. Under these conditions, the reaction yield achieved 100\% (alcohol 80\% and ketone about $20 \%$ ). After discounting the quantity of products originated from the control reactions, it was possible to conclude that the alcohol yield obtained based on the catalytic activity of the two MPs immobilized on C was about $60 \%$, suggesting for the first time that some synergistic effect caused by both metalloporphyrins immobilized on $\mathrm{C}$ and light radiation took place.

In spite of all the different solids used as supports for the immobilization of metalloporphyrins (Table 1), there is an expectation that MPs organized as porous materials, either using a porous solid as support (e.g., macroporous LDH, mesoporous silicas or zeolites), ${ }^{85-87,89-91,99,100,125}$ or integrated into porous structures, such as metal-organic frameworks (MOFs) ${ }^{27,80,140,141,145,146,192,193}$ or porous organic polymers (e.g., PIM = polymers of intrinsic microporosity), ${ }^{149,153}$ will have enhanced catalytic performance, mainly regarding the selectivity, relative to non-porous materials, since the confinement effect for reagents and/or products may lead to unusual and unexpected selectivities for the same reaction relative to a homogeneous environment.

With this in view, recently Antonangelo et al. ${ }^{147}$ reported the synthesis of new porphyrinic materials, constructed by a nucleophilic substitution reaction between two different porphyrins (Por1 and Por2) and metalloporphyrins (MnPor1 and MnPor2) (Figure 9), resulting in four new stable porphyrin-based microporous network polymers (named P1-P4), with apparent Brunauer-Emmett-Teller (BET) surface areas in the range $600-1200 \mathrm{~m}^{2} \mathrm{~g}^{-1}$.

The catalytic performance of the four polymeric solids was evaluated in oxidation reactions using cyclooctene and cyclohexane. No catalytic activity was found for polymer P1, without any metal ions in the porphyrins' core. However, excellent efficacy was found for the three other network polymers (P2, P3 and P4) using, for example, cyclohexane as substrate (Figure 10). Under the experimental conditions used, higher yield and selectivity were achieved for the alcohol product in comparison with their precursors MnPor1 and MnPor2 (Figure 10, MnPor1 = MP1 and MnPor2 = MP2) in homogeneous catalysis. These results suggested the stability of both metalloporphyrins heterogenized as a network structure of the polymers, and also indicated that an effective catalytic reaction was occurring within the porous/surface structure of the porous polymer network, and probably an effective and efficient confinement effect of reagents (substrate + iodosylbenzene) led to the high efficiency and selectivity of the reaction in comparison with the same reaction relative to a homogeneous environment. Hence, the metalloporphyrin-based materials described for the prepared solids P2, P3 and P4 possess all the prerequisites to acting as good heterogeneous biomimetic catalysts: high density of active centers, excellent chemical and thermal stability, and straightforward synthesis.

Finally, the reusability and stability of the solids P2, P3 and P4 were evaluated and all of them showed similar performance of first use. Besides the interesting catalytic reactions of the solids, the presence of two metalloporphyrins in the structure of the same polymeric solid makes them promising materials for a further application as bi-functional solid catalysts, particularly if two different metal centers are introduced that can be used in different catalytic processes. ${ }^{194}$

The idea that the use of support with organized structure can contribute to unusual and unexpected selectivity was also observed when MPs were immobilized on a support based on LDH but especially prepared to present ordered macropores. After the immobilization of a family of anionic $\mathrm{FeP}$, the resulting solids were used for the oxidation of heptane. ${ }^{120}$

The three dimensionally ordered macroporous LDHs (named 3DM-MOX) were prepared by the 'inverse opals method' using polystyrene (PS) opals as template (Figure 11). The nanotextured hydrotalcite LDH solid $\mathrm{Mg}_{2} \mathrm{Al}(\mathrm{OH})_{6}\left(\mathrm{CO}_{3}\right)_{0.5}$ was prepared over the PS spheres, by the coprecipitation method of divalent and trivalent metallic cations, taking place inside the voids of the PS colloid crystal after successive infiltrations (Figure 11b). PS spheres were easily removed by moderate calcination (Figure 11c) and the resulting oxide mixtures were restructured as LDH macroporous LDHs in solutions of different anionic iron(III) porphyrins (Figure 11d).

Alkane oxidation in the terminal position, to yield alcohols or linear acids, is of great interest to the chemical industry since the products (e.g., alcohol and ketones) selectively obtained in the terminal position by oxidation of linear alkanes are valuable chemicals with a range of applications (e.g., intermediates for fine chemicals and preparation of precursors for the polymeric preparation of Nylon 6,6, etc). ${ }^{170,194-200}$ Linear alkanes are difficult to hydroxylate, since the alkane $\mathrm{C}-\mathrm{H}$ bond is notoriously inert because of its high bond strength (from 101 to 99 and to $96 \mathrm{kcal} \mathrm{mol}^{-1}$ for primary, secondary and tertiary carbon atoms, respectively), making alkanes ideal solvents for use with very reactive oxidation catalysts. Additionally, 


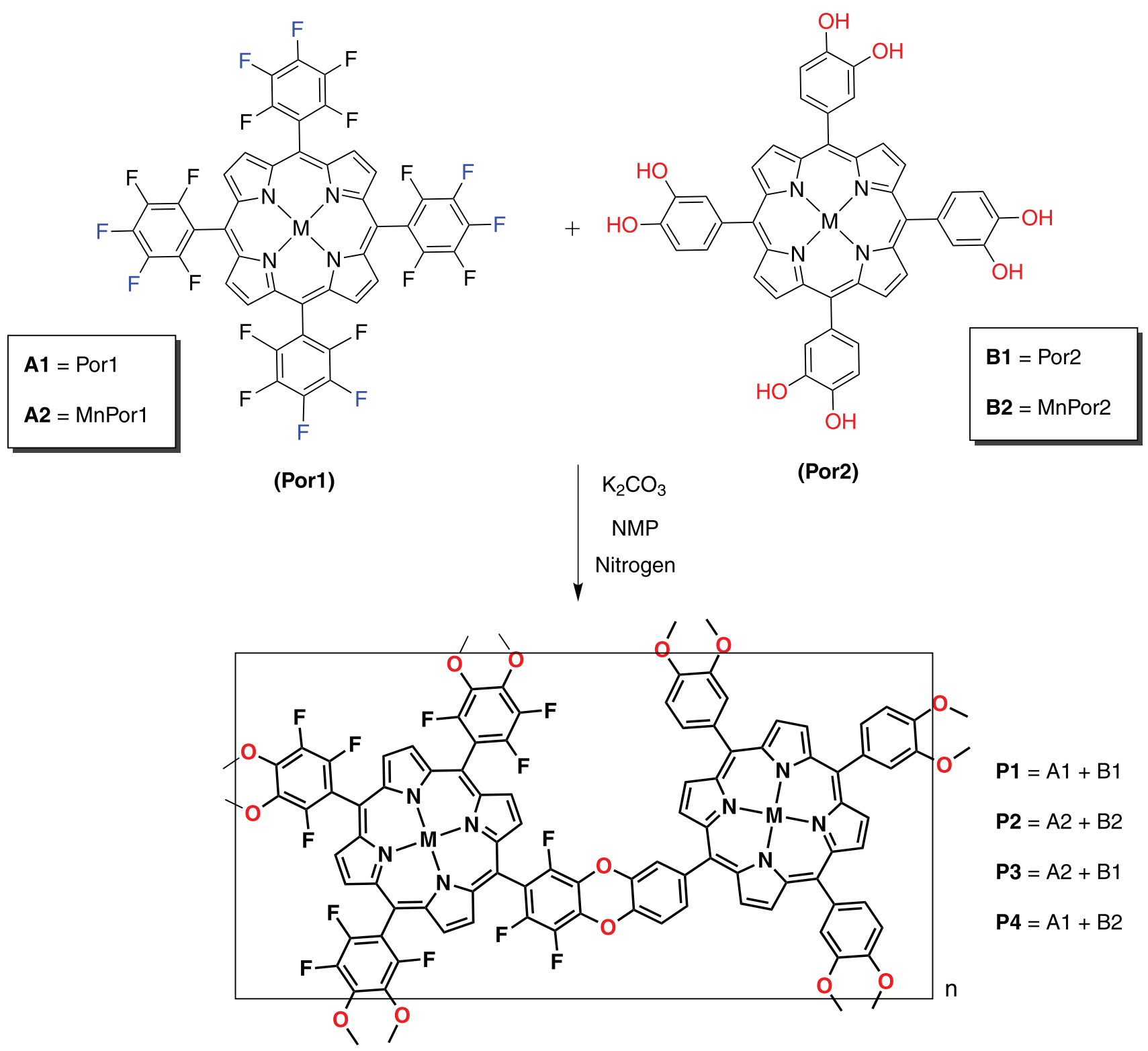

Porphyrins-based Network Polymers

Figure 9. Schematic representation of the structures of the porphyrin-based network polymers prepared by Antonangelo et al. ${ }^{147}$ (P1, P2, P3 and P4), following the method proposed by McKeown et al. ${ }^{151}(\mathrm{M}=2 \mathrm{H}$ or manganese(III) ion).

the activation energies for subsequent oxidations of an alcohol are similar to the energy required for the initial hydroxylation of the starting alkane, resulting in a mixture of alcohol, ketone/aldehyde, and carboxylic acid products in most alkane oxidation reactions. The similarity of methylene $\mathrm{C}-\mathrm{H}$ bond strengths in a linear alkane and the lack of functional groups that can serve direct catalysis make the selective hydroxylation of these compounds especially challenging. Studies have been conducted in an attempt to make efficient clean catalysts that are able to promote oxidation reactions in mild conditions, using environmentally acceptable oxidants such as hydrogen peroxide, which generates only $\mathrm{H}_{2} \mathrm{O}$ and $\mathrm{O}_{2}$ after catalysis. ${ }^{199}$ Enzymes, metal-complex catalysts, and metal-based biomimetic systems are known to induce regioselective transformations of linear alkanes, but their application is still difficult. In this sense, metalloporphyrin systems have been intensively investigated as catalysts for these less reactive substrates in a biomimetic way.

In the absence of steric constraints, the regioselectivity for $\mathrm{C}-\mathrm{H}$ bond activation during the hydroxylation of linear alkanes is expected to be determined by the relative bond dissociation energy. ${ }^{195} \mathrm{~A}$ similar statistical product distribution is expected for carbon products at positions 2 and 3 , and there is no significant preference for one carbon 2 (or 3) over another carbon 2 (or 3). ${ }^{17,195}$ 


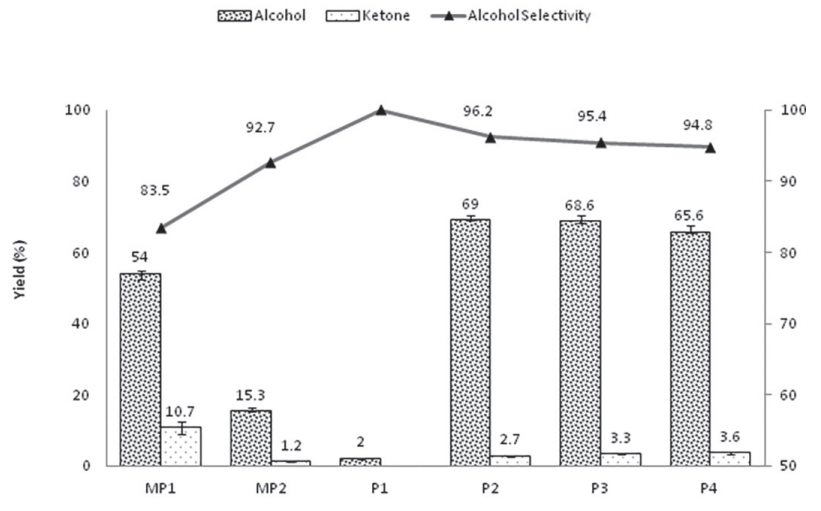

Figure 10. Cyclohexane oxidation reaction using PhIO as oxidant catalyzed by MnPor1 (MP1) and MnPor2 (MP2) (homogeneous catalysis) and by $\mathrm{P} 1, \mathrm{P} 2, \mathrm{P} 3$ and $\mathrm{P} 4$ (heterogeneous catalysis). The control reaction $(\mathrm{PhIO}+$ cyclohexane, absence of catalyst $)$ did not present significant results. Catalyst $/ \mathrm{PhIO} /$ Substrate molar ratio $=1: 10: 1000$. The product yields for cyclohexanol (alcohol) and cyclohexanone (ketone) were calculated based on the amount of PhIO used in the reactions. Results represent reactions performed in at least duplicate.

Although heptane oxidation can lead to different alcohol and ketone products (in the 1, 2, 3 and 4 carbon chain positions), the catalytic results obtained for the FeP immobilized in macro LDH (5,10,15,20-tetrakis(2,6-difluoro-3-sulfonatophenyl) porphyrinate)iron(III) ([Fe(TDFSPP)]-3DMMOXLDH, Table 3) after $24 \mathrm{~h}$ of reaction showed that the FeP promoted good selectivity for alcohols in position 1, and some alcohol production was also observed in position 2 and 3. Reactions with metalloporphyrins in homogeneous

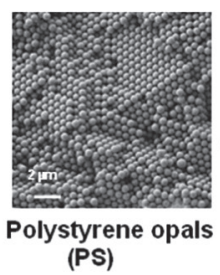

(a)

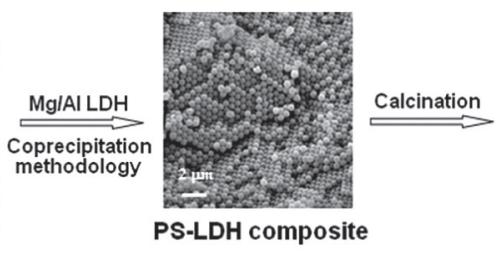

(b)

systems are usually selective for alcohol in positions 2 or 3 , as observed for the FeP used (Table 3) in reaction for 1 or $24 \mathrm{~h}$, because of the lesser energy necessary for activation of these $\mathrm{C}-\mathrm{H}$ bonds compared with position 1 , for example. ${ }^{120}$

The Suslick and co-workers ${ }^{200}$ observed some selectivity for position 1 of hexane when they used a metalloporphyrin [5,10,15,20-tetrakis(2',4',6'-triphenylphenylporphyrinate) manganese(III)] [Mn(TTPPP)] in homogeneous systems and attributed this selectivity behavior to the structural characteristic of the porphyrin that directed the access of the linear alkane to the metal center in a restricted way, more exposing the $\mathrm{C}-\mathrm{H}$ bond at carbon 1 , giving rise to shape selectivity. ${ }^{195}$

The results presented by [Fe(TDFSPP)]-3DMMOXLDH after $24 \mathrm{~h}$ of catalytic reaction suggested that the immobilization of the $\mathrm{FeP}$ on the porous materials containing relatively small cavities or narrow channels was responsible for promoting the interesting regioselectivity in the oxidation of terminal linear alkanes. The FeP-macro LDH assembly probably generated a restricted space that was suitable for the approach of the $n$-alkane so that terminal oxidation was favored over secondary carbon oxidation. The results also suggested that the longer reaction time ( $1 \mathrm{~h}$ versus $24 \mathrm{~h}$ ) favors substrate access to the catalytic active species confined in the structure of the solid support, improving the efficiency and selectivity of the catalyst for oxidation in the substrate's terminal position.

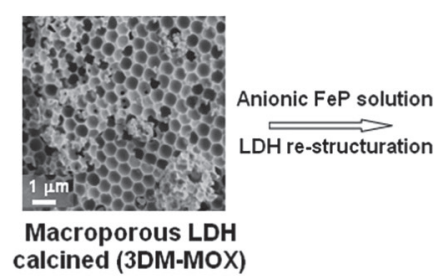

(c)

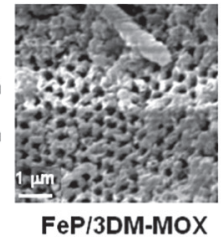

(d)

Figure 11. Schematic representation of the solid resulting from the immobilization of an anionic iron(III)porphyrin on the dimensionally ordered macroporous LDH (FeP/3DM-MOX).

Table 3. Example of catalytic results for the oxidation of heptane by PhIO using the anionic [Fe(TDFSPP)] in a homogeneous system and immobilized ${ }^{120}$

\begin{tabular}{|c|c|c|c|c|c|c|}
\hline \multirow{2}{*}{ Catalyst $^{\mathrm{a}}$} & \multirow{2}{*}{ time / $\mathrm{h}$} & \multicolumn{3}{|c|}{ Alcohol yield / \% } & \multicolumn{2}{|c|}{ Total yield / \% } \\
\hline & & $1-\mathrm{ol}^{\mathrm{c}}$ & $2-\mathrm{ol}^{\mathrm{d}}$ & $3-\mathrm{ol}^{\mathrm{e}}$ & Alcohol $^{\mathrm{f}}$ & Ketone ${ }^{g}$ \\
\hline \multirow{2}{*}[\mathrm{Fe}(\mathrm{TDFSPP})]{$^{\mathrm{b}}$} & 1 & 2 & 3 & 3 & 8 & $<1$ \\
\hline & 24 & 3 & 4 & 3 & 10 & $<1$ \\
\hline \multirow{2}{*}{ [Fe(TDFSPP)]-3DM-MOXLDH } & 1 & 2 & 6 & 5 & 13 & 2 \\
\hline & 24 & 12 & 4 & 4 & 20 & 2 \\
\hline
\end{tabular}

a Reaction conditions: purged argon, catalyst/oxidant/heptane molar ratio $=1: 10: 1000$; solvent mixture dichloromethane/acetonitrile 1:1 (v/v) at room temperature (yields obtained after $1 \mathrm{~h}$ of reaction based on starting PhIO); ${ }^{b}$ homogeneous catalysis was carried out under identical conditions, in dichloromethane/acetonitrile 1:1 solvent mixture (v/v); ${ }^{\mathrm{cd}, \mathrm{e} e}$ total alcohol (ol) yield (1-heptanol, 2-heptanol and 3-heptanol, respectively); ${ }^{\mathrm{f}}$ total alcohol yield; ${ }^{g}$ total ketone (one) yield (4-heptanone). In this work, the alcohol in position 4 was not monitored. 

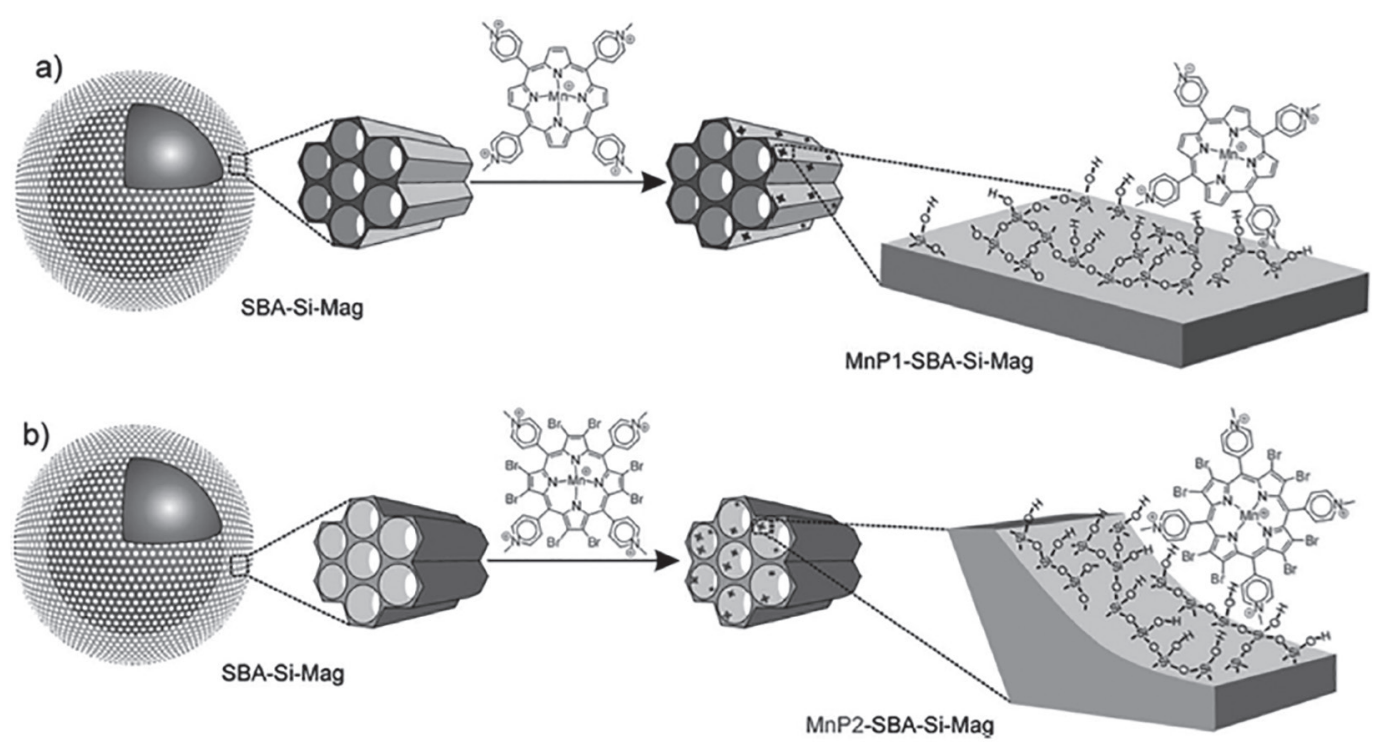

Figure 12. Schematic representation of the immobilization of the cationic MnPs on SBA-Si-Mag by electrostatic attraction: (a) on the support solid surface and (b) inside the porous system solid support (figure reproduced from reference 87 with copyright permission 2018 from Elsevier).

More recently, Ucoski et al. ${ }^{87}$ reported the unusual catalytic performance of a solid based on electrostatic immobilization of a manganese porphyrin on mesoporous silica SBA-15 modified magnetite (Figure 12). The idea that the mesoporous material could give unusual selectivity to the catalytic reaction was again explored.

The use of magnetic particles is an interesting strategy for easy, fast and efficient recovery of the catalyst from the reaction, favoring recyclability and improving the main aspect of the heterogeneous catalysis, which is the recovery and reuse of the catalyst over many reaction cycles. These objectives have contributed to an increasing number of reports on the use of solids based on magnetic particles for various catalytic purposes. . $6,87,92-94,201-204^{-10}$

A solid support based on mesoporous SBA-15 silica (Santa Barbara Amorphous) ${ }^{205}$ and magnetite particles $\left(\mathrm{F}_{3} \mathrm{O}_{4}\right)$ was prepared (named SBA-Si-Mag), and then two cationic MnPs (here named as $\mathrm{MnP} 1$, and $\mathrm{MnP}$ 2) were immobilized on them, generating two solid catalysts
(MnP1-SBA-Si-Mag and MnP2-SBA-Si-Mag, Figure 12). The third generation porphyrin MnP2 was used to search for the best efficiency of the cationic catalyst. ${ }^{45}$

For the oxidation of $n$-hexane (Table 4), MnP1-SBA-Si-Mag yielded 4\% total alcohol, higher than observed for $\mathrm{MnP} 1$ in a homogeneous medium (1\%). However, the results were not unusual. The higher yield observed for the immobilized catalyst may be the result of a combination of different factors, like the greater resistance of MnP1 to the reaction conditions when supported and the avoidance of problems due to its poor solubility in the reaction medium when the catalyst is fixed on the surface of the support (Figure 12).

On the other hand, MnP2-SBA-Si-Mag afforded an overall yield of $8 \%$ alcohols. This alcohol yield was higher than that observed for $\mathrm{MnP} 2$ in homogeneous conditions (1.8\% total alcohol). Besides being more efficient for hydroxylation of $n$-hexane than MnP1-SBA-Si-Mag, the solid MnP2-SBA-Si-Mag showed high selectivity

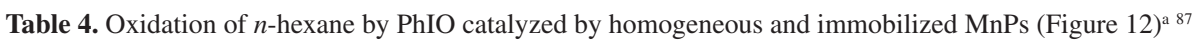

\begin{tabular}{lcccc}
\hline \multirow{2}{*}{ Catalyst $^{\mathrm{a}}$} & \multicolumn{3}{c}{$n$-Hexane alcohol yield $/ \%^{\mathrm{c}}$} & Alcohol total yield $/ \%^{\mathrm{c}}$ \\
\cline { 2 - 4 } MnP1 $^{\mathrm{b}}$ & 1-ol $^{\mathrm{d}}$ & - & 2 -ol & 3 -ol \\
MnP1-SBA-Si-Mag & - & 0.3 & 0.7 & 1.0 \\
MnP2 $^{\mathrm{b}}$ & - & 1.5 & 2.5 & 4.0 \\
MnP2-SBA-Si-Mag $^{\mathrm{f}}$ & 5.7 & 0.5 & 1.3 & 1.8 \\
\hline
\end{tabular}

${ }^{a}$ Oxidation of $n$-hexane by $\mathrm{PhIO}$ catalyzed by $\mathrm{MnP}$ in homogeneous and heterogeneous systems. Reaction conditions: catalyst/oxidant/substrate molar ratio of 1:50:2500. The reactions were carried out in a solvent mixture of acetonitrile/dichloromethane $(1: 1, \mathrm{v} / \mathrm{v})$, at room temperature, under argon for $1 \mathrm{~h}$; ${ }^{b}$ homogeneous catalysis was performed under conditions identical to those employed for the heterogeneous catalysis; ' $\mathrm{PhIO}$. All catalysts tested showed no detectable ketone production; d,e,falcohol 1-hexanol, 2-hexanol and 3-hexanol, respectively. Homogeneous (PhIO) and heterogeneous (SBA-Si-Mag) reactions in the absence of catalyst did not yield a significant amount of the products. 
for 1-carbon oxidation, with a 5.7\% 1-hexanol yield. On the other hand, when MnP2 was used in homogeneous catalysis, no production of 1-hexanol was observed and the production of alcohol in positions 2 and 3 was statistically similar to the results obtained for $\mathrm{MnP} 1$, used either in homogeneous or heterogeneous catalysis. The ideal support-catalyst assembly was seen to be responsible for causing this unusual selectivity to position 1 oxidation. This was probably caused by the relative arrangement of $\mathrm{MnP} 2$ with the $\beta$-pyrrolic bromine atoms inside the pores of SBA-15 in the SBA-Si-Mag support (Figure 12), in comparison to the arrangement of MnP1, which seemed to be immobilized on the surface of the support and showed selectivity to 2- and 3-hexanol.

Although other metalloporphyrins have been immobilized on SBA-15 and other mesoporous silica solids (HMS, MCM-41), ${ }^{85,86,88-91,94}$ similar selectivity results were not reported before. This astonishing selectivity for position $\mathrm{C}-1$ indicates that the immobilization of MnP2 inside the pores of SBA-Si-Mag produced a selective catalyst for the oxidation of the terminal carbon of $n$-hexane, which is another amazing example of a non-innocent support contribution to the unusual selectivity of solids resulting from immobilization of MPs.

\section{Collaboration between Brazilian Research- ers and Universidade de Aveiro (Portugal) in Catalytic Studies Involving Metalloporphyrins and other Applications}

This part of the review discusses some research involving porphyrins and analogues that has emerged from the collaboration between some Brazilian researchers and the tetrapyrrolic research group of the Department of Chemistry of Universidade de Aveiro, in the last 20 years. This focus does not intend to minimize the importance of other collaborative work involving other Portuguese and Brazilian groups and institutions. .11,206-216 $^{-10}$

In these collaborative efforts, the research was developed in different fields, like catalysis, structural characterization of tetrapyrrolic macrocycles by mass spectrometry, ${ }^{217-220}$ development of new synthetic strategies leading to the functionalization at $\beta$-pyrrolic positions ${ }^{221-233}$ and meso positions $^{230,234,235}$ (namely with sugar units), ${ }^{236}$ and of new compounds with potential applications as photosensitizers in photodynamic therapy (PDT) ${ }^{237-239}$ and antimicrobial photodynamic therapy (aPDT) ${ }^{238,240}$ and also as sensors. ${ }^{241-244}$

In this section, special attention is given to some synthetic strategies developed to prepare new catalyst species and the results obtained when their efficacy was evaluated in oxidative processes. Additionally, brief references are made to some synthetic approaches to obtain new compounds with adequate features for use as photosensitizers.

In 2005, groups headed by Cavaleiro and co-workers ${ }^{245}$ reported the efficacy of a $\mathrm{Mn}^{\mathrm{III}}$ complex of chlorin 1 and also of the cationic analogue 2 (Scheme 1) as catalyst in the oxyfunctionalization of hydrocarbons under homogeneous conditions. The free-base of those chlorin ligands was obtained from the reaction of [5,10,15,20-tetrakis (pentafluorophenylporphyrin)] ([ $\left.\mathrm{H}_{2}(\mathrm{TPFPP})\right]$, (Figure 4, $\mathrm{R}=4$ ) with the azomethine ylide generated in situ from $\mathrm{N}$-methylglycine and paraformaldehyde in refluxing toluene, according to the method discovered by the Aveiro group. In fact, at the end of the nineties, the Aveiro group reported, for the first time, that porphyrins can react as dienophiles in Diels-Alder reactions ${ }^{246}$ or as dipoloraphiles in 1,3-dipolar cycloaddition reactions. ${ }^{246}$ These synthetic approaches were widely explored by our and other groups for the functionalization of $\beta$-pyrrolic positions of porphyrins and analogues. ${ }^{247,248}$

$\mathrm{Mn}$ (chlor)- 1 was obtained by insertion of $\mathrm{Mn}^{\mathrm{III}}$ in chlorin 1 and $\mathrm{Mn}$ (chlor)-2 was prepared under similar conditions after quaternization of chlorin 1 with methyl iodide (Scheme 1).

The catalytic efficacy of the two $\mathrm{Mn}^{\text {III }}$ chlorins was evaluated using cyclohexane as substrate in the presence of the oxidants iodosylbenzene (PhIO) and $\mathrm{H}_{2} \mathrm{O}_{2}$, using imidazole as co-catalyst, and the results were compared with those obtained with the $\mathrm{Mn}^{\mathrm{III}}$ complexes of the starting porphyrin $\left[\mathrm{H}_{2}(\mathrm{TPFPP})\right]$ and the cationic 5,10,15,20-tetrakis(2,3,5,6-tetrafluoro4-trimethylammoniumphenyl)porphyrin (Figure $4, \mathrm{R}=\mathbf{1 8}$ ). The results obtained showed that the $\mathrm{Mn}^{\mathrm{III}}$ chlorins are promising catalysts for oxidation reactions, since moderate to good yields of oxygenated products (total yields between 13 to $60 \%$ with alcohol/ketone ratios ranging from about 66:34 to 100:0) were obtained.

An interesting conclusion from these studies, by doing experiments in the presence of the radical inhibitor bromotrichloromethane and competitive cyclooctane/ (Z)-cyclooctene oxidation reactions, was the different reactivity of the $\mathrm{Mn}$ (chlor)/ $\mathrm{H}_{2} \mathrm{O}_{2}$ systems, which favored the epoxidation process. So, it was suggested that the epoxide formation in the reactions promoted by these $\mathrm{Mn}^{\mathrm{III}}$ chlorins/ $\mathrm{H}_{2} \mathrm{O}_{2}$ is mediated by $\mathrm{Mn}^{\text {III }}$ (chlor)OOH (Scheme 2) instead of by the $\mathrm{Mn}^{\mathrm{V}}=\mathrm{O}$ species (responsible by the radical cage escape pathway in the formation of alcohols and ketones). The Mn(chlor) hydroperoxy complex was a more efficient species for epoxidation than for the production of the alkyl radical.

Taking into account that the immobilization of catalysts is an important strategy to minimize the cost of catalyst 

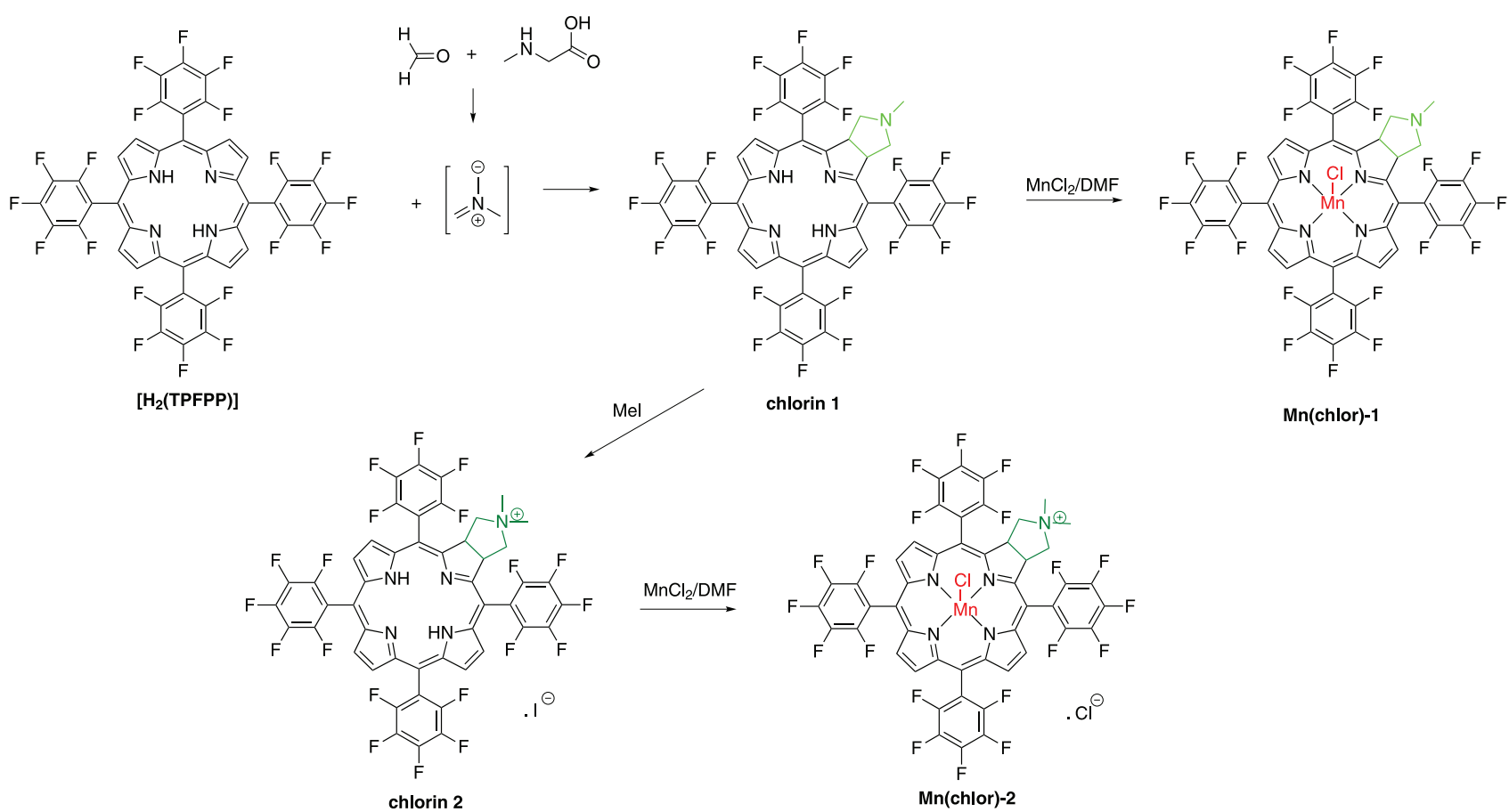

Mn(chlor)-1

Scheme 1. Synthesis of $\mathrm{Mn}^{\mathrm{III}}$ chlorins by a 1,3-dipolar cycloaddition with azomethine ylide.

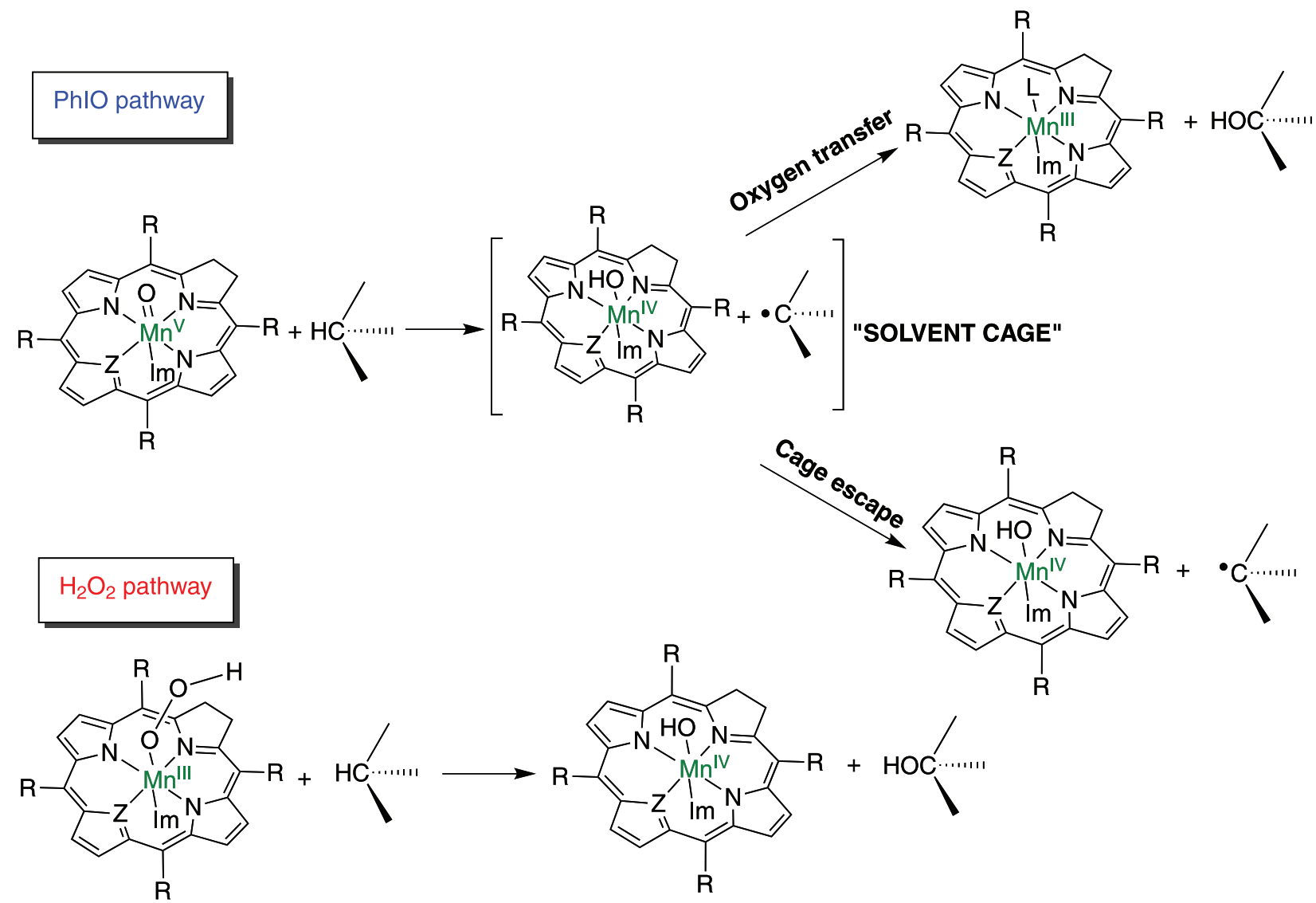

Scheme 2. Proposed pathway mediated by chlorins in the presence of $\mathrm{PhIO}$ and $\mathrm{H}_{2} \mathrm{O}_{2}$ (adapted from references 65 and 245).

synthesis by allowing easy recovery and reutilization, as discussed in the previous section 2, Pires et al. ${ }^{249}$ reported the synthesis of the analogue $\mathrm{Mn}$ (chlor)-3 aiming to ally the characteristic robustness of the well-known 


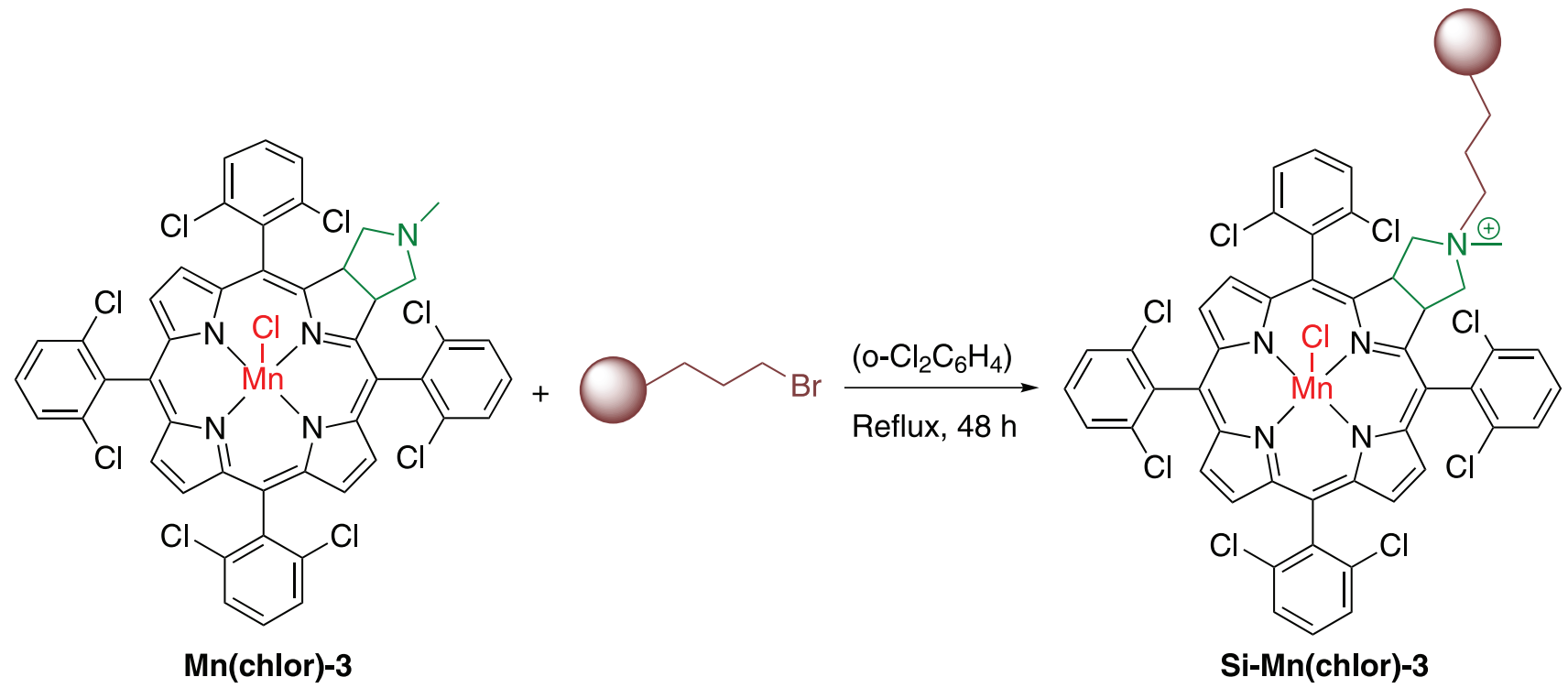

Scheme 3. Immobilization of Mn(chlor)-3 on a modified silica support.

5,10,15,20-tetrakis(2,6-dichlorophenyl)porphyrinate) manganese(III) [Mn(TDCPP)Cl] (Figure $4, \mathrm{R}=\mathbf{3}$ ), with the possibility of immobilizing it on an inorganic solid support, through the pyrrolidine ring (Scheme 3). The most appropriate solvent to immobilize the chlorin on the modified 3-bromopropylsilica (BPS) was o-dichlorobenzene.

The efficacy of this material as a biomimetic oxidation catalyst was tested, using $(Z)$-cyclooctene as substrate in the presence of hydrogen peroxide or $t$-butyl hydroperoxide as oxidant. The results showed that depending on the conditions, the silica-supported manganese chlorin exhibited high catalytic efficiency and good recyclability in the presence of $t$-butyl hydroperoxide. The slower kinetics of the reaction when the recycled catalyst was used was attributed to the probable presence of a mixture of catalytic species (e.g., $\mathrm{Mn}^{\mathrm{III}}$ and $\mathrm{Mn}^{\mathrm{IV}}$ ) in the next runs.

As an extension of previous studies, $\mathrm{Mn}$ (chlor)-1 (prepared from $\left[\mathrm{H}_{2}\right.$ (TPFPP)]) and $\mathrm{Mn}$ (chlor)-3 (prepared from the porphyrin $\left[\mathrm{H}_{2}(\mathrm{TDCPP})\right]$ ) were subsequently immobilized on silica by the sol-gel process and the catalytic activity of the resulting solids (Mn(chlor)-1-Si and Mn(chlor)3-Si) was investigated for the oxidation of cyclooctene, cyclohexene and cyclohexane with iodosylbenzene (PhIO) or hydrogen peroxide as oxidant. ${ }^{250}$ The immobilization on silica prepared by the sol-gel process was performed in the presence of Mn(chlor) using alkoxysilane TEOS, a mixture of tetrahydrofuran (THF) and water as solvent and $\mathrm{HCl}$ as catalyst, in order to favor the maximum hydrolysis before starting the condensation process.

The results showed that the $\mathrm{Mn}^{\mathrm{III}}$ chlorins exhibit excellent catalytic activity under homogeneous catalysis, similar to that observed for the corresponding $\mathrm{Mn}^{\text {III }}$ porphyrins of $\left[\mathrm{H}_{2}(\mathrm{TPFPP})\right]$ and $\left[\mathrm{H}_{2}(\mathrm{TDCPP})\right]$. The immobilized $\mathrm{Mn}^{\mathrm{III}}$ chlorins required longer reaction times to afford product yields similar to those obtained under homogeneous conditions, suggesting that the catalyst immobilization hinders the access of the reactants to the metal center. However, after being recovered, they could be reused at least three more times. In the oxidation of cyclohexene, the preferential formation of the epoxide was observed, while in the oxidation of cyclohexane, both catalysts were selective for alcohol formation.

The slight difference in the catalytic behavior of $\mathrm{Mn}$ (chlor)-1 versus $\mathrm{Mn}$ (chlor)-3 was explained by considering that the substituents of the meso-phenyl groups of each chlorin ligand were responsible for a different distribution (more or less entrapped) during the immobilization process.

In the context of synthesizing new catalysts, the Brazilian researcher Rodrigo de Paula (during his PhD studies in Aveiro) developed new catalytic systems based on non-immobilized and immobilized manganese porphyrins bearing imidazolyl units. ${ }^{251-253}$ These studies showed that the poor catalytic activity of the neutral porphyrin under homogeneous conditions was improved after the cationization of the heterocyclic units. Additionally, when those units were linked to adequate functionalized solid supports like a Merrifield resin (MR) or a functionalized silica gel (SG), great catalytic improvement was observed. The best results were obtained with the MR system for the oxidation of $(Z)$-cyclooctene, styrene, cyclohexene and geraniol using $\mathrm{H}_{2} \mathrm{O}_{2}$ as oxidant. Additionally, good recyclability (up to four times) without a dramatic loss of the catalytic efficiency was found. Some considerations 


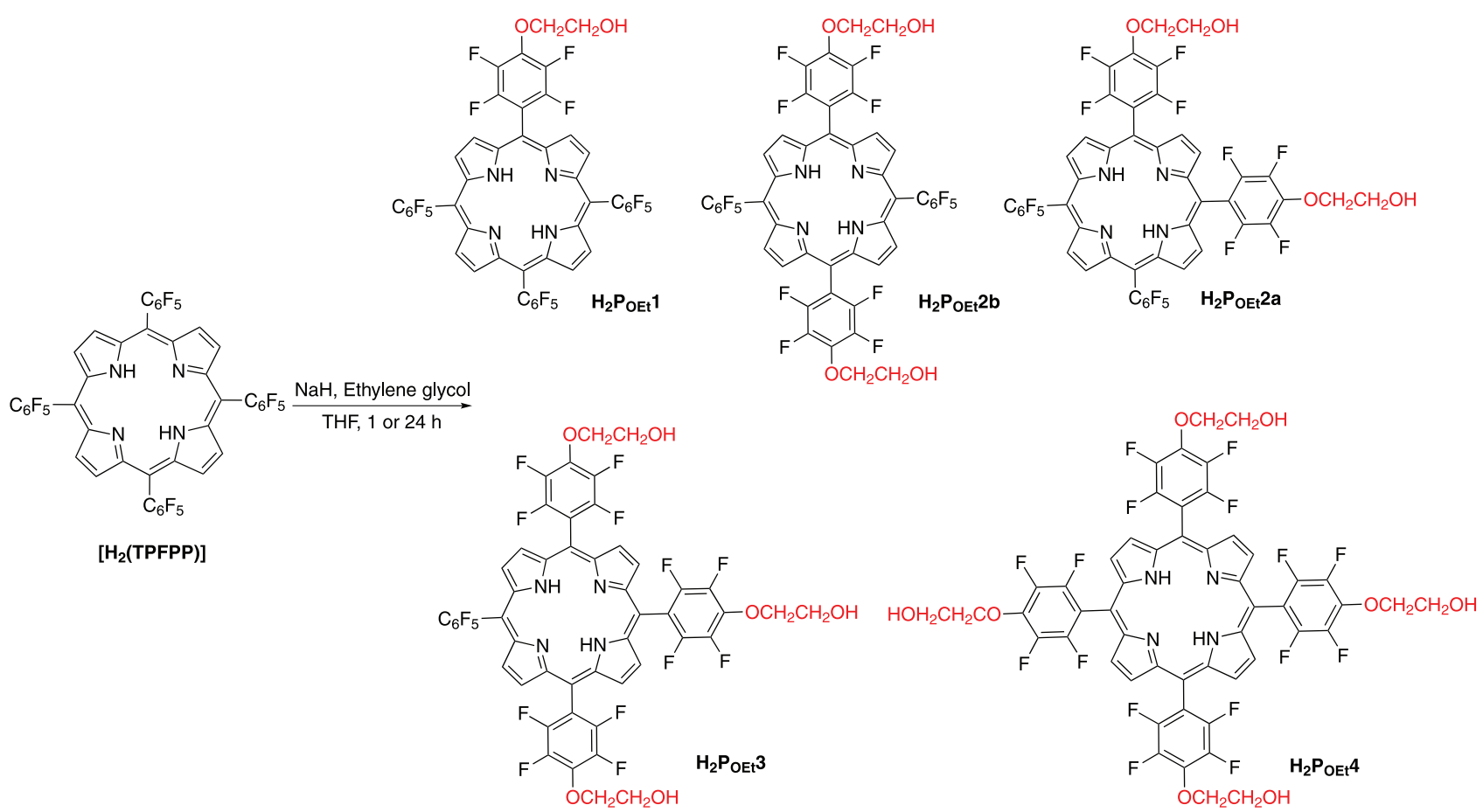

Scheme 4. Synthetic access to substituted porphyrins at the p-position of the meso-aryl groups with one to four hydroxyalkyloxy substituents.

concerning the high efficiency of the MR system in comparison with the SG one were put forward considering the molecular orbital stabilization achieved by the linkage between the metallocomplex and each support.

Based on the easy replacement of the fluorine atom in the $p$-position of pentafluorophenyl units by nucleophiles, ${ }^{254}$ some new porphyrins and materials were developed considering that strategy to provide 5,10,15,20-tetrakis (pentafluorophenyl)porphyrin $\left(\left[\mathrm{H}_{2}(\mathrm{TPFPP})\right]\right)$ with adequate functionalities for further heterogenization.

To investigate possible catalytic uses, the reaction between $\left[\mathrm{H}_{2}\right.$ (TPFPP) $]$ and ethylene glycol was performed, yielding a series of five substituted porphyrins $\left(\mathrm{H}_{2} \mathrm{P}_{\mathrm{OEt}} 1-\mathrm{H}_{2} \mathrm{P}_{\mathrm{OEt}} 4\right.$, Scheme 4$)$ at the $p$-position of the meso-aryl groups with one to four hydroxyalkyloxy groups (Scheme 4). ${ }^{60,65}$

The $\mathrm{Fe}^{\mathrm{III}}$ and the $\mathrm{Mn}^{\mathrm{III}}$ complexes of the mono- and tetrasubstituted free-base derivatives $\left(\mathrm{H}_{2} \mathrm{P}_{\mathrm{OEt}} 1\right.$ and $\left.\mathrm{H}_{2} \mathrm{P}_{\mathrm{OEt}} 4\right)$ were prepared (Figure 13), and the corresponding complexes were further immobilized on two supports: LDH and silica (synthesized by the sol-gel process). ${ }^{60}$ Castro et al. ${ }^{60}$ showed that the metalloporphyrins $\mathrm{FeP}_{\mathrm{OEt}} 1, \mathrm{FeP}_{\mathrm{OEt}} 4, \mathrm{MnP}_{\mathrm{OEt}} 1$ and $\mathrm{MnP}_{\mathrm{OEt}} 4$ under homogeneous and heterogeneous media provided good catalytic conversions in $(Z)$-cyclooctene

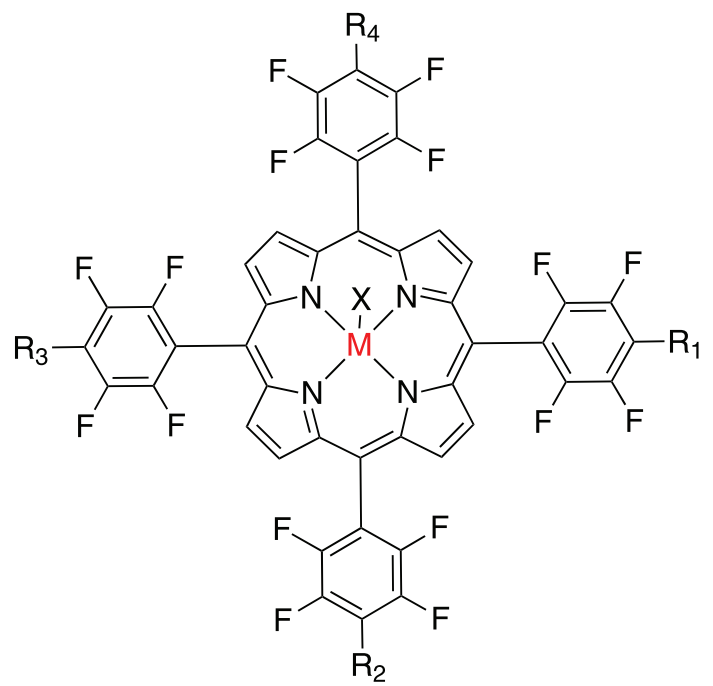

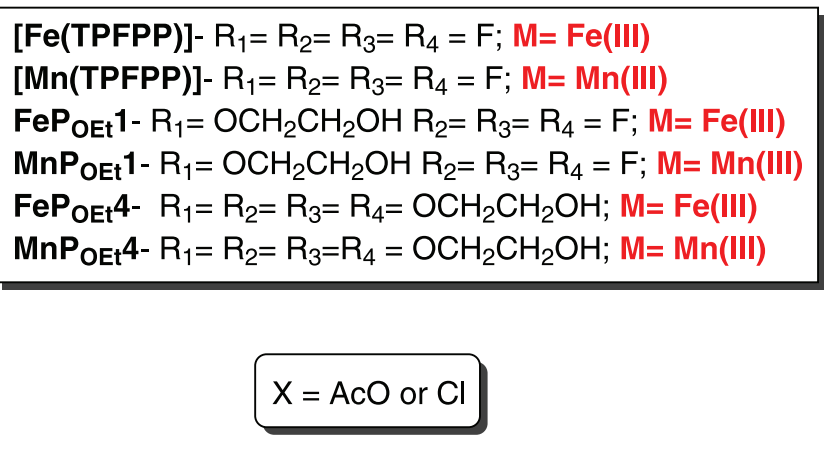

[Fe(TPFPP)]- $\mathrm{R}_{1}=\mathrm{R}_{2}=\mathrm{R}_{3}=\mathrm{R}_{4}=\mathrm{F} ; \mathrm{M}=\mathrm{Fe}$ (III)

[Mn(TPFPP)]- $R_{1}=R_{2}=R_{3}=R_{4}=F ; M=M n(I I I)$

FeP ${ }_{\text {OEt }} 1-\mathrm{R}_{1}=\mathrm{OCH}_{2} \mathrm{CH}_{2} \mathrm{OH} \mathrm{R} \mathrm{R}_{2}=\mathrm{R}_{3}=\mathrm{R}_{4}=\mathrm{F} ; \mathrm{M}=\mathrm{Fe}$ (III)

MnPoEt $1-\mathrm{R}_{1}=\mathrm{OCH}_{2} \mathrm{CH}_{2} \mathrm{OH} \mathrm{R} \mathrm{R}_{2}=\mathrm{R}_{3}=\mathrm{R}_{4}=\mathrm{F} ; \mathrm{M}=\mathrm{Mn}$ (III)

FePoEt4- $\mathrm{R}_{1}=\mathrm{R}_{2}=\mathrm{R}_{3}=\mathrm{R}_{4}=\mathrm{OCH}_{2} \mathrm{CH}_{2} \mathrm{OH} ; \mathrm{M}=\mathrm{Fe}$ (III)

$\mathrm{MnP}_{\mathrm{OEt}} 4-\mathrm{R}_{1}=\mathrm{R}_{2}=\mathrm{R}_{3}=\mathrm{R}_{4}=\mathrm{OCH}_{2} \mathrm{CH}_{2} \mathrm{OH} ; \mathrm{M}=\mathrm{Mn}$ (III)

$$
\mathrm{X}=\mathrm{AcO} \text { or } \mathrm{Cl}
$$

Figure 13. Schematic representation of $\mathrm{Fe}^{\mathrm{III}}$ and $\mathrm{Mn}^{\mathrm{III}}$ complexes of porphyrins bearing one $\left(\mathrm{H}_{2} \mathrm{P}_{\mathrm{OEt}} 1\right)$ and four $\left(\mathrm{H}_{2} \mathrm{P}_{\mathrm{OEt}} 4\right)$ hydroxyalkyloxy moieties. 
oxidation (71 to $96 \%$ ). In cyclohexane oxidation, the catalysts were more selective for alcohol than for ketone. In the case of heterogeneous catalysis, the immobilized metalloporphyrins produced slightly lower yields compared with homogeneous catalysis, but had the major advantage of retaining their activity for at least three cycles in the case of $(Z)$-cyclooctene oxidation.

Further catalytic studies involving the complete series of the $\mathrm{Mn}^{\mathrm{III}}$ complexes of $\left[\mathrm{H}_{2}(\mathrm{TPFPP})\right]$ derivatives bearing one to four hydroxyalkyloxy moieties showed that the catalysts' performance depends on the number of ethylene glycol moieties present and on the cocatalyst used. ${ }^{65}$ These studies were performed at room temperature using (Z)-cyclooctene and cyclohexane as substrates and $\mathrm{H}_{2} \mathrm{O}_{2}$ or $\mathrm{PhIO}$ as oxidants. For both substrates, the most efficient catalyst in the presence of $\mathrm{H}_{2} \mathrm{O}_{2}$ and ammonium acetate as cocatalyst was the $\mathrm{Mn}^{\mathrm{III}}$ complex bearing three ethylene glycol moieties $\left(\mathrm{MnP}_{\mathrm{OEt}} 3\right)$. Additionally, in the oxidation of cyclohexane in the presence of iodosylbenzene (PhIO) as oxidant, all the substituted $\mathrm{Mn}^{\text {III }}$ complexes were more efficient than the parent non-substituted $\mathrm{Mn}^{\mathrm{III}}$ complex of $\left[\mathrm{H}_{2}(\mathrm{TPFPP})\right]$. During the preparation of this series of derivatives, the tetrasubstituted free-base porphyrin $\left(\mathrm{H}_{2} \mathrm{P}_{\mathrm{OEt}} 4\right)$ was further isolated and studied in the solid state, by using single-crystal $\mathrm{X}$-ray diffraction analysis.

The ligand porphyrin "template", $\left[\mathrm{H}_{2}(\mathrm{TPFPP})\right]$, was also used as a platform to prepare the tetrasubstituted galactodendritic conjugate porphyrin $\left(\mathrm{H}_{2} \mathrm{P}_{\text {Gal }} 2\right)$, which after metalation with $\mathrm{Cu}^{\mathrm{II}}$ acetate in excess yielded the solid material $\mathrm{Cu}_{4} \mathrm{CuP}_{\mathrm{Ga}} 2 \mathrm{~S}$ (Scheme 5). ${ }^{192}$

The coordination of the copper(II) complex of $\mathrm{H}_{2} \mathrm{P}_{\text {Gal }} 2$ $\left(\mathrm{CuP}_{\text {Gal }} 2\right)$ with zinc(II) acetate afforded a second structured material, designated $\mathrm{Zn}_{4} \mathrm{CuP}_{\text {Gal }} 2 \mathrm{~S}$. The catalytic activity of this new coordination polymer using $(Z)$-cyclooctene and catechol as substrates confirmed that $\mathrm{Cu}_{4} \mathrm{CuP}_{\mathrm{Gal}} 2 \mathrm{~S}$ (Figure $4, \mathrm{R}=\mathbf{2 6}$ ) was able to mimic the catecholase activity of cytochrome P-450 and was reusable after recovery and reactivation.

In the same context, the reaction of $\left[\mathrm{H}_{2}(\mathrm{TPFPP})\right]$ with 4-mercaptobenzoic acid afforded, among others derivatives, porphyrins bearing one and four 4-mercaptobenzoic moieties. ${ }^{26}$

The results obtained showed that the $\mathrm{Fe}^{\mathrm{III}}, \mathrm{Mn}^{\mathrm{III}}$ and $\mathrm{Cu}^{\text {II }}$ complexes bearing one or four 4-mercaptobenzoic moieties (Figure 14) provided good to excellent yields during the catalytic oxidation of (Z)-cyclooctene, cyclohexane, and heptane under homogeneous conditions, and the product profile was dependent on the porphyrin structure and the metal. The tetra-substituted free-base porphyrin, after metalation with $\mathrm{Cu}^{\mathrm{II}}$ ions, yielded a structured and very insoluble solid, and the investigation of its catalytic activity for the oxidation of $(Z)$-cyclooctene in a heterogeneous medium proved that the new metalloporphyrin was an excellent catalyst for $(Z)$-cyclooctene epoxidation.

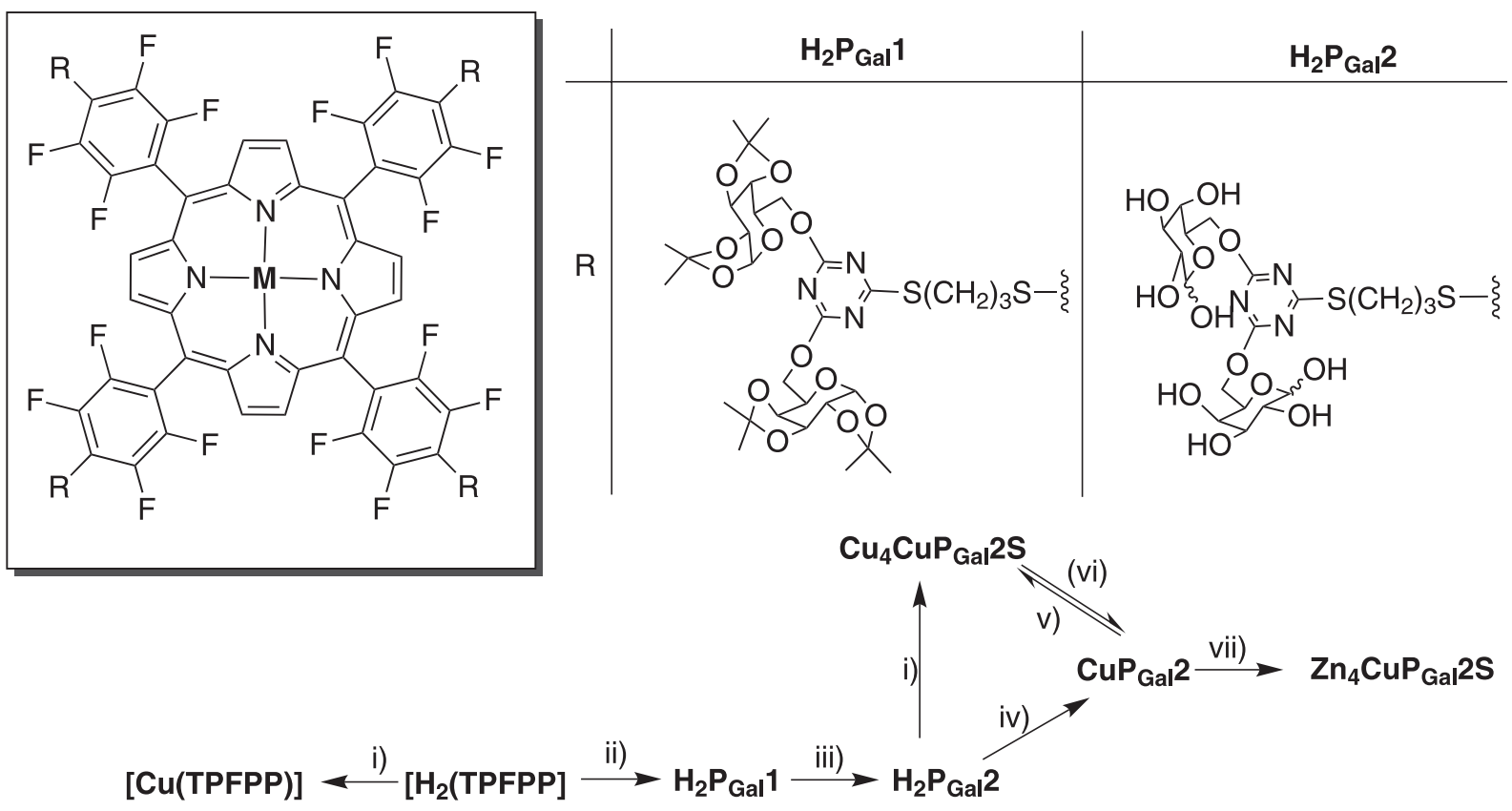

i) $1: 5 \mathrm{Cu}(\mathrm{OAC})_{2}$, DMF, $120^{\circ} \mathrm{C}$; ii) dendrimer GalProt., DIPEA, DMF, $50^{\circ} \mathrm{C}, 24 \mathrm{~h}$; iii) TFA:H ${ }_{2} \mathrm{O}(9: 1)$, rt, 30 min.; iv) $1: 1 \mathrm{Cu}(\mathrm{OAc})_{2}$, DMF, $120^{\circ} \mathrm{C}$; v) $1: 4 \mathrm{Cu}(\mathrm{OAc})_{2}$, DMF, $120^{\circ} \mathrm{C}$; vi) $\mathrm{HCl}$ (solution) vii) 1:4 $\mathrm{Zn}(\mathrm{OAc})_{2}$, DMF, $120^{\circ} \mathrm{C}$. 


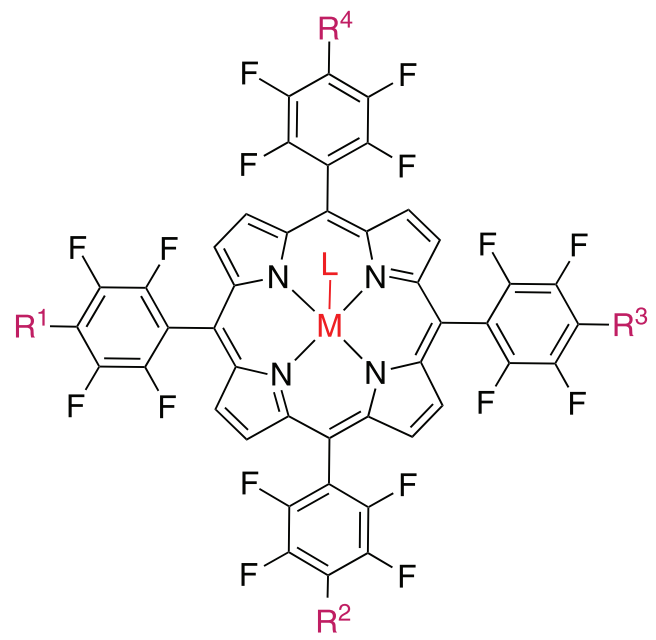

FeP $_{\text {Merc }} 1-\mathrm{R}^{1}=\mathrm{SC}_{6} \mathrm{H}_{4} \mathrm{COOH} ; \mathrm{R}^{2}=\mathrm{R}^{3}=\mathrm{R}^{4}=\mathrm{F} ; \mathrm{M}=\mathrm{Fe}(\mathrm{III})$

$\mathrm{MnP}_{\text {Merc }} 1-\mathrm{R}^{1}=\mathrm{SC}_{6} \mathrm{H}_{4} \mathrm{COOH} ; \mathrm{R}^{2}=\mathrm{R}^{3}=\mathrm{R}^{4}=\mathrm{F} ; \mathrm{M}=\mathrm{Mn}(\mathrm{III})$

FeP ${ }_{\text {Merc }} 4-R^{1}=R^{2}=R^{3}=R^{4}=S_{6} H_{4} \mathrm{COOH} ; M=F e(I I I)$

$\mathrm{MnP}_{\text {Merc }} 4-\mathrm{R}^{1}=\mathrm{R}^{2}=\mathrm{R}^{3}=\mathrm{R}^{4}=\mathrm{SC}_{6} \mathrm{H}_{4} \mathrm{COOH} ; \mathrm{M}=\mathrm{Mn}(\mathrm{III})$

CuP $_{\text {Merc }} 4-\mathrm{R}^{1}=\mathrm{R}^{2}=\mathrm{R}^{3}=\mathrm{R}^{4}=\mathrm{SC}_{6} \mathrm{H}_{4} \mathrm{COOH} ; \mathrm{M}=\mathrm{Cu}(\mathrm{II})$

Figure 14. Schematic representation of $\mathrm{Fe}^{\mathrm{III}}, \mathrm{Mn}^{\mathrm{III}}$ and $\mathrm{Cu}^{\mathrm{II}}$ complexes of porphyrins bearing one and four 4-mercaptobenzoic units; $\left(\mathrm{M}^{2}=\mathrm{Mn}^{\mathrm{III}}\right.$ or $\mathrm{Fe}^{\mathrm{III}}$, $\mathrm{L}=$ counter ion).

Additionally, in alkane oxidation the alcohols were selectively obtained in good yields.

Castro et al. ${ }^{255}$ evaluated the catalytic activity of the copper-based porphyrins $\mathrm{CuP}_{\mathrm{NH} 2 \mathrm{R}} 1$ (Figure $4, \mathrm{R}=\mathbf{2 5}$ ) and $\mathrm{CuP}_{\mathrm{NH} 2 \mathrm{R}} 2$ (Figure $4, \mathrm{R}=\mathbf{6}$ ) obtained by metalation of the corresponding amino free base derivatives $\mathrm{H}_{2} \mathrm{P}_{\mathrm{NH} 2 \mathrm{R}} 1$ and $\mathrm{H}_{2} \mathrm{P}_{\mathrm{NH} 2 \mathrm{R}} 2$ (obtained by adequate functionalization of $\left[\mathrm{H}_{2}(\mathrm{TPFPP})\right]$, Scheme 6) and also of the solid $\mathrm{CuP}_{\mathrm{NH} 2 \mathrm{R}} 1 \mathrm{~S}$ obtained from the reaction of $\mathrm{H}_{2} \mathrm{P}_{\mathrm{NH} 2 \mathrm{R}} 1$ with an excess of $\mathrm{Cu}^{\mathrm{II}}$ acetate (10 equiv.) (Scheme 6). The catalytic efficacy of these complexes was studied under homogeneous $\left(\mathrm{CuP}_{\mathrm{NH} 2 \mathrm{R}} 1\right.$ and $\left.\mathrm{CuP}_{\mathrm{NH} 2 \mathrm{R}} 2\right)$ and heterogeneous $\left(\mathrm{CuP}_{\mathrm{NH} 2 \mathrm{R}} 1 \mathrm{~S}\right)$ conditions in the presence of 3,5-di-tert-butylcatechol (3,5-DTBC) and catechol, in the presence of air, with or without $\mathrm{H}_{2} \mathrm{O}_{2}$. The results showed that the new copper porphyrins
$\mathrm{CuP}_{\mathrm{NH} 2 \mathrm{R}} 1$ and $\mathrm{CuP}_{\mathrm{NH} 2 \mathrm{R}} 2$ and the $\mathrm{CuP}_{\mathrm{NH} 2 \mathrm{R}} 1 \mathrm{~S}$ material were able to efficiently mimic the activity of catechol oxidase, affording good conversion of 3,5-DTBC and catechol to the corresponding quinone derivatives. It was also observed that the $\mathrm{CuP}_{\mathrm{NH} 2 \mathrm{R}} 1 \mathrm{~S}$ can be easily reused, maintaining its activity for more than three catalytic cycles. The better performance of $\mathrm{CuP}_{\mathrm{NH} 2 \mathrm{R}} 2$ was attributed to the presence of the bulkier groups in the parent $\left[\mathrm{H}_{2}(\mathrm{TPFPP})\right]$ compared to $\mathrm{CuP}_{\mathrm{NH} 2 \mathrm{R}}$ 1. It was also concluded that the steric effect of the substrates also influenced the catalytic performance of the complexes, since for the same reaction time, and under similar conditions, the oxidation of 3,5-DTBC occurred at lower rates than catechol. For $\mathrm{CuP}_{\mathrm{NH} 2 \mathrm{R}} 1$ and $\mathrm{CuP}_{\mathrm{NH} 2 \mathrm{R}} 2$, the best results were obtained in the aqueous system. The explanation for these results was the fact that the catalyst

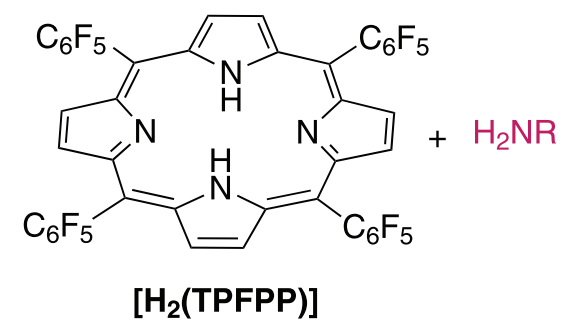<smiles>Cc1ccc(S(=O)(=O)NCCCP=[R2]PN)cc1</smiles>

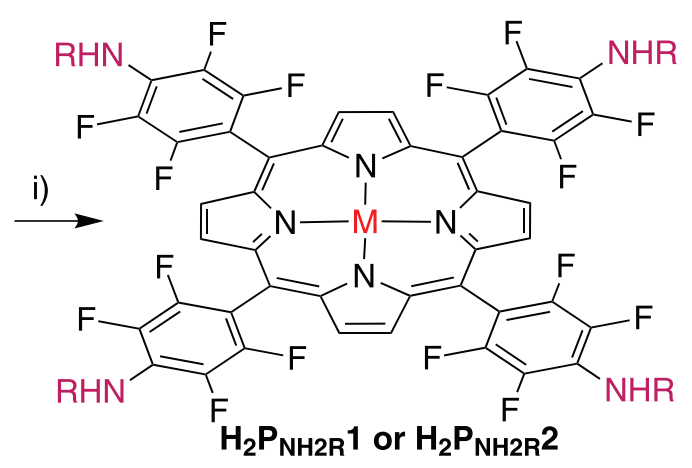

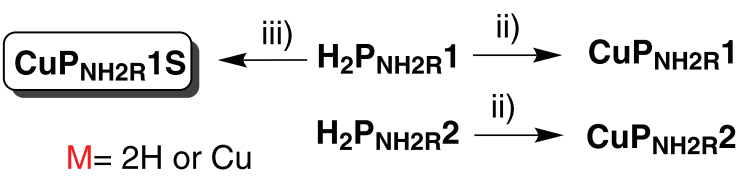

i) NMP, $800 \mathrm{~W}, 1$ bar, $200^{\circ} \mathrm{C}$; ii) $\mathrm{Cu}(\mathrm{AcO})_{2}$ (1 equiv.), DMF, $120^{\circ} \mathrm{C}, 24 \mathrm{~h}$;

iii) $\mathrm{Cu}(\mathrm{AcO})_{2}$ (10 equiv.), DMF, $120^{\circ} \mathrm{C}, 24 \mathrm{~h}$.

Scheme 6. Synthetic access to the copper(II) complexes of amino porphyrins $\mathrm{H}_{2} \mathrm{P}_{\mathrm{NH} 2 \mathrm{R}} 1$ and $\mathrm{H}_{2} \mathrm{P}_{\mathrm{NH} 2 \mathrm{R}} 2$ and to the solid $\mathrm{CuP}_{\mathrm{NH} 2 \mathrm{R}} 1 \mathrm{~S}$. 
and substrate are in the same phase, facilitating access of the reactants to the metal ion center.

It is well known that a key route for the elimination of xenobiotics after their introduction into an organism is in general initiated by oxidation reactions catalyzed by enzymes of the cytochrome P-450 group, and these enzymes are responsible for phase I metabolism of about $75 \%$ of known pharmaceuticals. ${ }^{256}$ The possibility to modulate the metabolic activation of those enzymes using synthetic porphyrins has been responsible for a large number of studies, due to their ease of operation, formation of several metabolites in adequate amounts for further pharmacological and toxicological evaluation, and reduction of animal testing and of problems associated with the isolation of natural enzymes.

Following their interest in this topic, ${ }^{257-260}$ in 2011 the Portuguese group in collaboration with Vitor Ferreira's group from Universidade Federal Fluminense (Niterói, $\mathrm{RJ})$ reported the biomimetic oxidation of lapachol (Scheme 7). ${ }^{261}$

This naphthoquinone is found in the heartwood of some trees of the Bignoniaceae family and has a wide
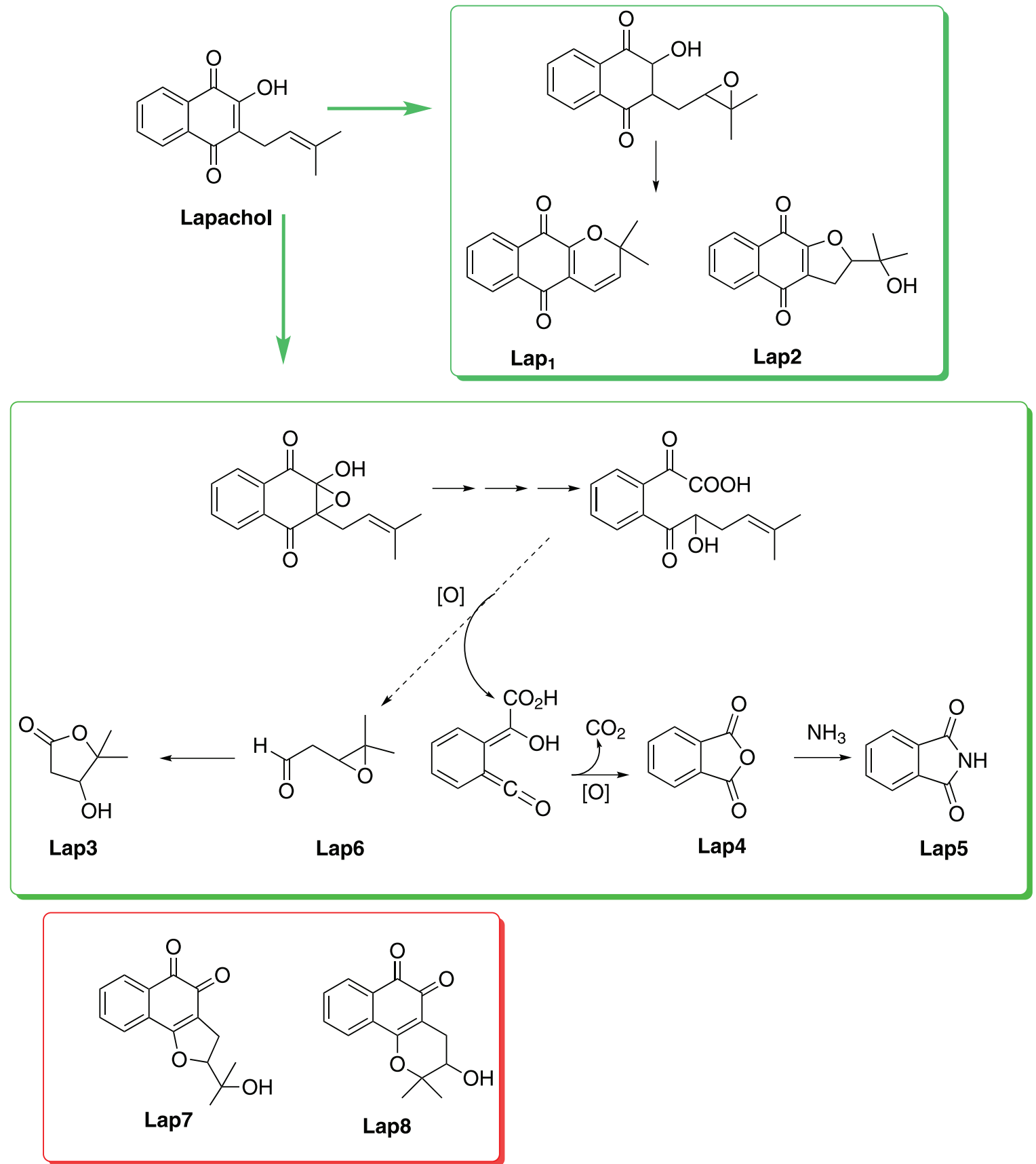

Scheme 7. Biomimetic oxidation of lapachol. 
spectrum of biological activities, such as anti-tumor, antibiotic, antimalarial, anti-inflammatory, anti-ulcer, antibacterial, fungicidal and trypanocidal activities. The studies were performed with aqueous $\mathrm{H}_{2} \mathrm{O}_{2}$ in the presence of $[\mathrm{Mn}(\mathrm{TDCPP})] \mathrm{Cl}$, and the preferential formation of the p-naphthoquinones Lap1 and Lap2 obtained was attributed to epoxidation of the side chain double bond. The formation of the other compounds (Lap3-Lap6) also identified was attributed to the epoxidation of the quinone ring double bond. ${ }^{261}$ The selectivity observed in the biomimetic oxidation of lapachol was different from the one using stoichiometric amount of $m$-CPBA, where the formation of the $o$-naphthoquinones Lap7 and Lap8 was favored. ${ }^{261}$

In the same context, the nor-lapachone derivatives $n$ Lap9 tethered with thio-substituents at position 3 of the furan ring synthesized according to a method developed by the Brazilian group was oxidized with aqueous $\mathrm{H}_{2} \mathrm{O}_{2}$ in the presence of $[\mathrm{Mn}(\mathrm{TDCPP})] \mathrm{Cl}$, affording the corresponding sulfonyl derivative $n$ Lap10 (Scheme 8). ${ }^{262}$

The evaluation of the antibacterial activities of the non-oxidized and oxidized lapachone derivatives against the Gram-negative bacterium Escherichia coli and the Gram-positive bacterium Staphylococcus aureus after their incorporation into polyvinylpyrrolidone (PVP) micelles showed that the PVP-formulations of the lapachones $n$ Lap9b-g and of the sulfonyl-lapachones $n$ Lap10e and $n$ Lap $10 \mathrm{~g}$ reduced the growth of $S$. aureus. ${ }^{261,262}$

Another field of interest involving Portuguese and Brazilian research groups in collaboration is related to the potential of porphyrins and analogues for use as photosensitizers in PDT and aPDT. Both approaches require the activation of a dye called photosensitizer (PSs) by an adequate light wavelength in the presence of molecular oxygen. Then, the activated PS transfers its excess energy or electrons to dioxygen $\left({ }^{3} \mathrm{O}_{2}\right)$ or substrate molecules, generating highly cytotoxic reactive oxygen species (ROS), especially singlet oxygen $\left({ }^{1} \mathrm{O}_{2}\right)$. The cytotoxic species are able to cause irreparable damage in different target biomolecules, depending on the intended action (oncological or non-oncological). ${ }^{262-266}$

Among the different PSs developed, chlorins exhibit photophysical properties similar to those of porphyrin macrocycles, but with intensified and red-shifted Q bands, making chlorin-containing systems even better candidates for PDT (activation in the near infrared (NIR) region with better light penetration in biological tissues).

Interestingly, it was in context of developing compounds for use as photosensitizers that in 2004, the researchers from Aveiro and Ribeirão Preto published one of their first papers, in J. Braz. Chem. Soc. ${ }^{267}$ That pioneer work reported the synthesis and the photophysical characterization of chlorins 4 and 5 (Figure 15) obtained from the asymmetric porphyrin 5,10,15-tris(pentafluorophenyl)-20-(4-pyridyl) porphyrin using the azomethine ylide generated in situ from $N$-methylglycine and paraformaldehyde in refluxing toluene, as describe previously in Scheme 1 for the symmetric $\left[\mathrm{H}_{2}\right.$ (TPFPP)]. The asymmetric porphyrin was obtained by a crossed Rothemund reaction involving the condensation of pyrrole with the adequate aldehydes (4-pyridinecarbaldehyde and pentafluorobenzaldehyde) in a stoichiometry that favored the formation of that porphyrin.

The photophysics, photochemical and photobleaching properties of chlorin 4 were evaluated and compared with the properties of chlorin 1. By using the uric acid test, the ability of chlorin 4 to produce an oxygen singlet was confirmed, hence it was considered a promising photosensitizer for PDT.

In 2008, de Oliveira et al. ${ }^{234}$ developed an elegant strategy to obtain the amphiphilic chlorins (protoporphyrin-IX dimethyl ester derivatives) PPIX-1a and PPIX-1b (Scheme 9) from protoporphyrin-IX dimethyl ester considering the reactivity of their double bonds as diene in Diels-Alder reactions. ${ }^{268}$ The cycloaddition reaction was performed in the presence of maleic anhydride, giving rise to the chlorin intermediates PPIX-a,b. The desired chlorins were isolated after the regioselective anhydride ring-opening in the presence of methanol.

Considering that an important limitation of topical PDT is related with the poor PSs penetration through biological barriers, like normal skin, the uptake of nanoparticles of lyotropic liquid crystals loaded with PPIX-1a and PPIX-1b was studied in vitro and in vivo. ${ }^{269}$ The results showed that this type of nanodispersion enabled a higher
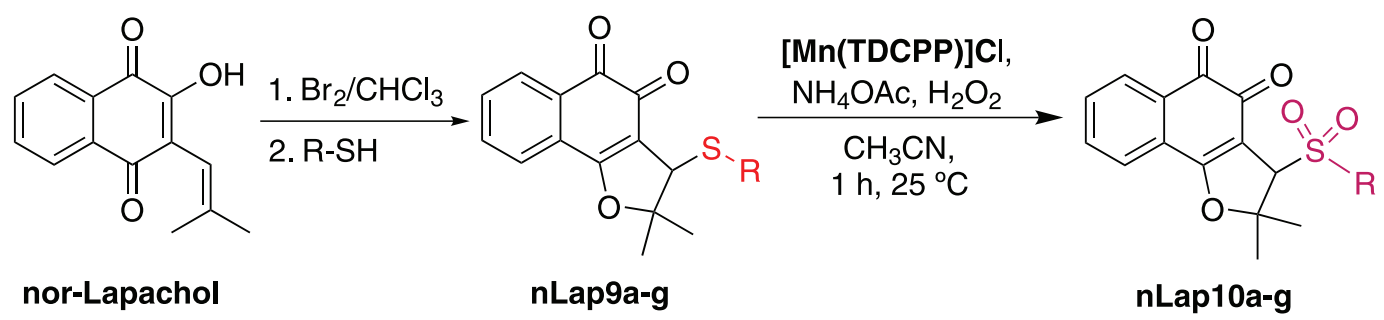

$R$

(a) $4-\mathrm{F}-\mathrm{C}_{6} \mathrm{H}_{4}$

(b) $4-\mathrm{Cl}-\mathrm{C}_{6} \mathrm{H}_{4}$

(c) $4-\mathrm{CH}_{3}-\mathrm{C}_{6} \mathrm{H}_{4}$

(d) $\mathrm{C}_{6} \mathrm{H}_{5}$

(e) $3-\mathrm{CH}_{3}-\mathrm{C}_{6} \mathrm{H}_{4}$

(f) $\mathrm{C}_{6} \mathrm{~F}_{5}$

(g) Cyclohexyl

Scheme 8. Biomimetic oxidation of naphthoquinones $n$ Lap9. 

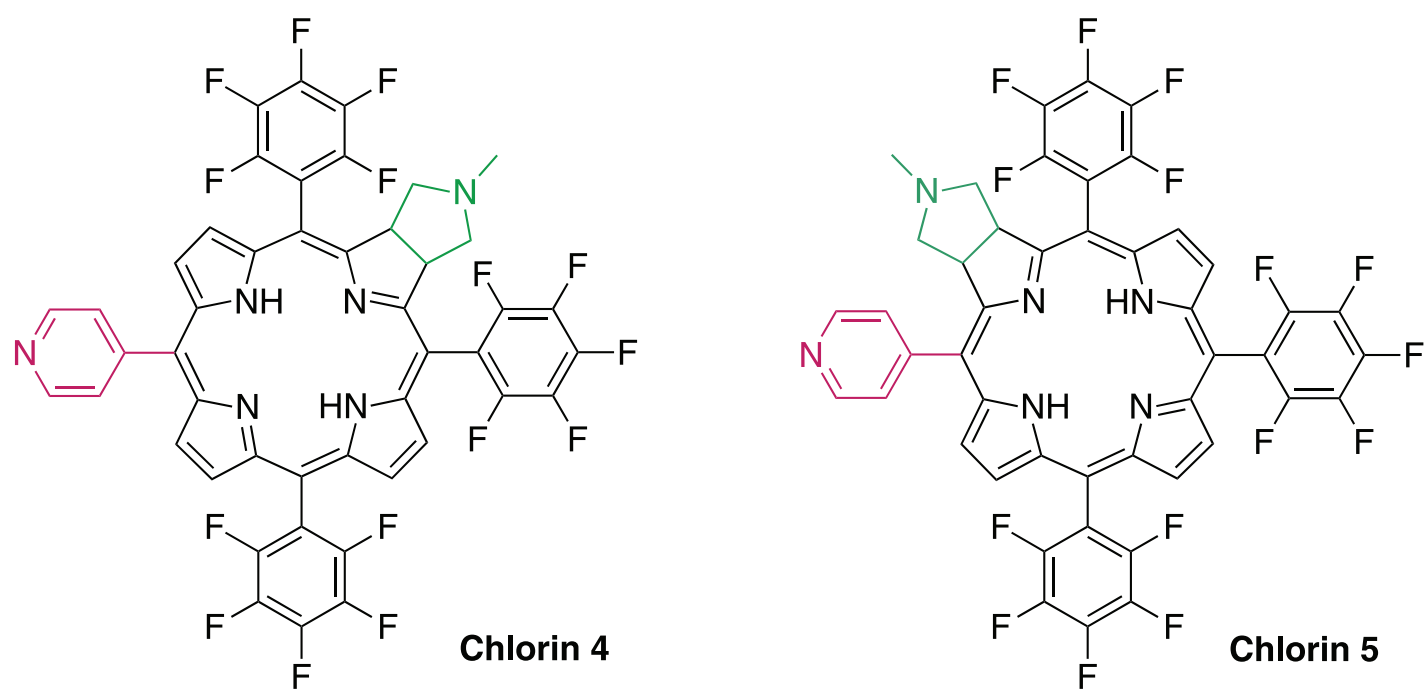

Figure 15. Structures of chlorins 4 and 5 obtained from the asymmetric porphyrin 5,10,15-tris(pentafluorophenyl)-20-(4-pyridyl)porphyrin.

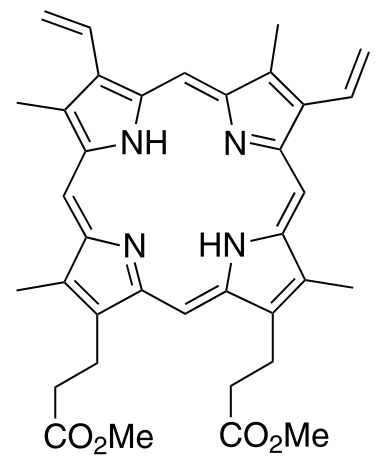

Protoporphyrin-IX dimethyl ester i)<smiles>O=C1C=CC(=O)O1</smiles>

dry toluene, reflux, $18 \mathrm{~h}$

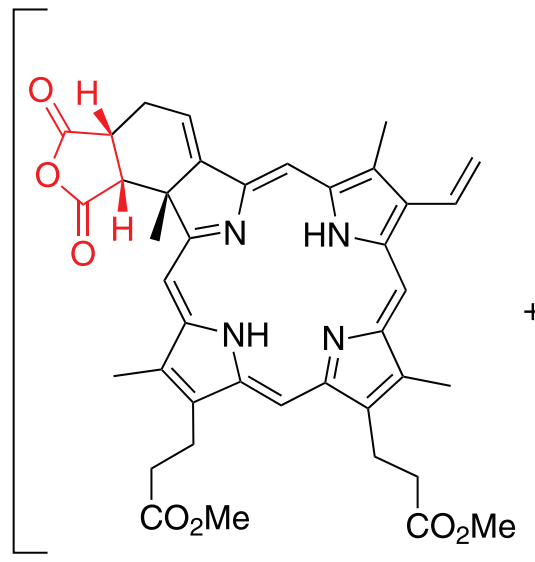

PPIX-a

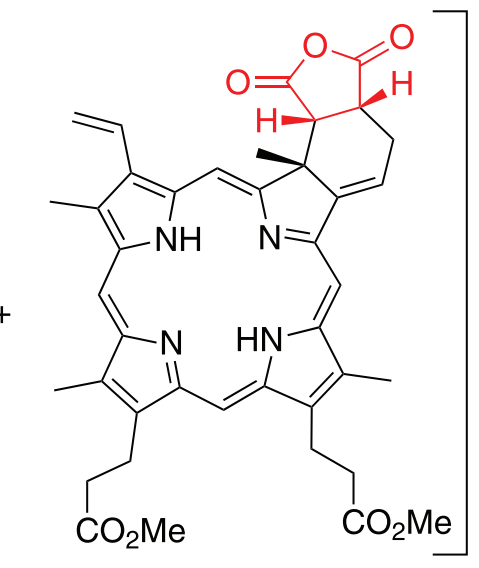

PPIX-b

ii) $\mathrm{CH}_{3} \mathrm{OH}$

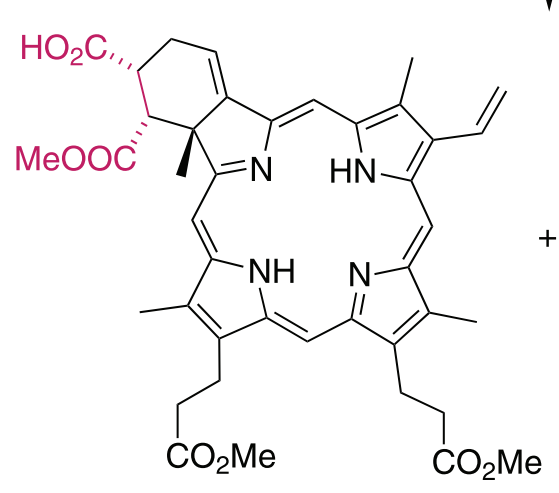

PPIX-1a

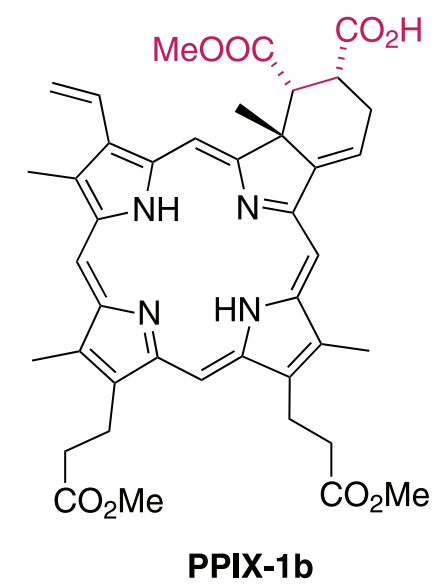

Scheme 9. Synthetic strategy used in the preparation of amphiphilic chlorin derivatives PPIX-1.

drug skin uptake compared with the control formulation used (chlorins PPIX-1a,b in polyethylene glycol), and consequently was effective to deliver PSs into the skin.
Considering the suitability of the pyrrolidine-fused chlorin derivatives to act as nucleophile, the Portuguese group envisaged the immobilization of chlorin 1 on the 

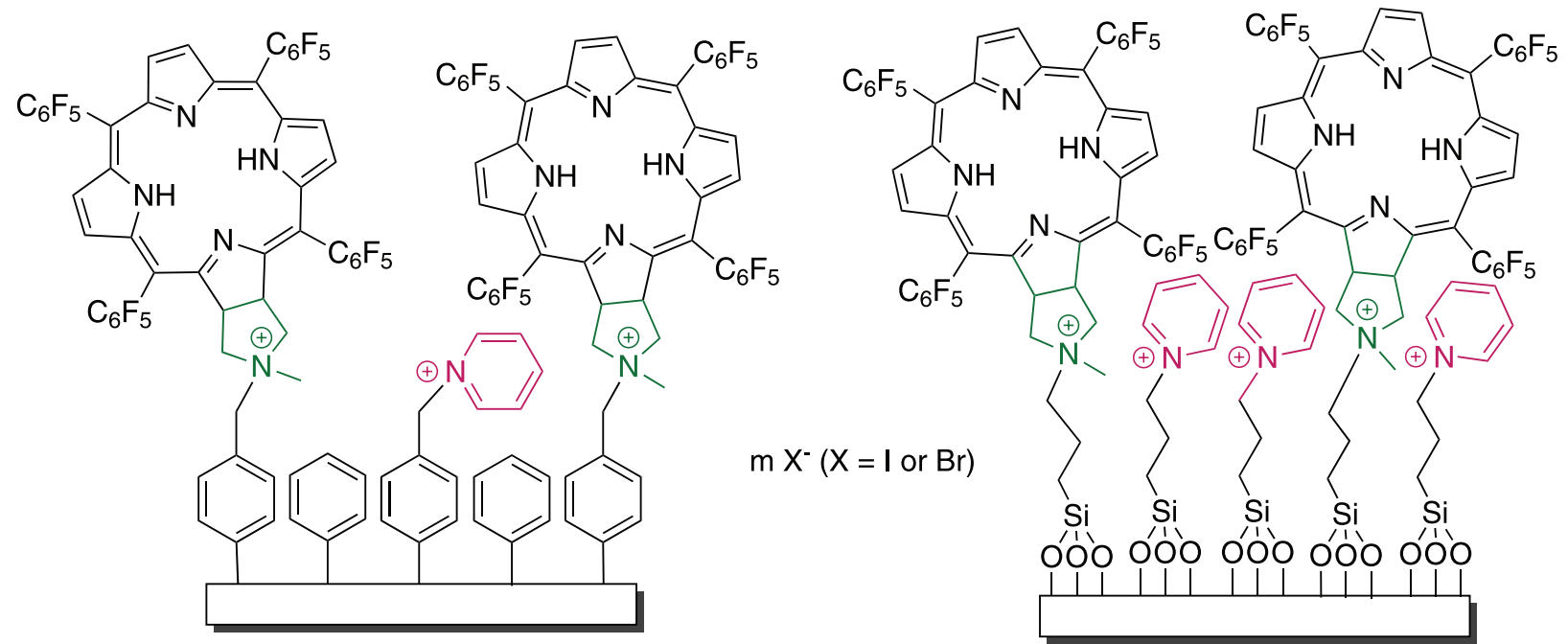

Figure 16. Chlorin 1 immobilized on a modified silica gel (SG) (right side) and Merrifield resin (MR) cationized with pyridine units (left side) $\left(\mathrm{m} \mathrm{X}^{-}=\right.$required counter anions).

commercially available 3-bromopropyl-functionalized silica and also on Merrifield resin-based materials, as an economically viable and environmentally friendly approach to allow successive recovery and removal of the PS material after photodynamic treatment (Figure 16). ${ }^{270,271}$

The study showed that the materials resulting from the immobilization of chlorin 1 on both commercial materials followed by further treatment with pyridine had high potential as PS for the inactivation of E. coli (ca. $3.0 \log$ reductions, $180 \mathrm{~min}$ of irradiation), even after three successive cycles of bacterial photoinactivation. So, these photoactive materials can be considered a good option for application in clinical and environmental areas.

Taking advantage of the suitable features of chitosan to act as a support for PS as well as its antimicrobial activity and film forming ability, Castro et al. ${ }^{139}$ reported the synthetic access to new materials obtained through the non-covalent incorporation of $\left[\mathrm{H}_{2}\right.$ (TPFPP)] and meso-tetraarylporphyrins bearing phenyl or pentafluorophenyl groups at the meso positions with or without acid groups $\left(\mathrm{H}_{2} \mathrm{P}_{\text {Merc }} \mathrm{OH}\right.$, $\mathrm{H}_{2} \mathrm{P}_{\text {Merc }} \mathrm{CO}_{2} \mathrm{H}$ and $\mathrm{H}_{2} \mathrm{PCO}_{2} \mathrm{H}$ ) in chitosan (Figure 17).

The effectiveness of the non-immobilized porphyrins and of the porphyrinic-chitosan films (PS-CF) to photoinactivate $L$. innocua and to prevent $L$. innocua biofilm development was evaluated and it was verified that the photodynamic inactivation was dependent on the porphyrin structure and also on the ability to produce ${ }^{1} \mathrm{O}_{2}$. The biofilm development was almost totally inhibited in the presence of PSs-CFs containing porphyrins $\left[\mathrm{H}_{2}(\mathrm{TPFPP})\right]$ and $\mathrm{P}_{\text {Merc }} \mathrm{OH}$ after irradiation with white light for $24 \mathrm{~h}$ (irradiance of $10 \mathrm{~mW} \mathrm{~cm}$ ) followed by incubation in the dark for $48 \mathrm{~h}$. These good results associated with the easy recovery of the films merit further investigation using other PSs and new biofilm-forming microorganisms with potential application as anti-fouling coating materials for the food industry. ${ }^{139}$

Phthalocyanines (Pcs) are another example of synthetic macrocycles with a close structural relation with porphyrins that have merited some attention in the collaborative research between Brazilian and Portuguese groups. ${ }^{272,273}$ In fact, phthalocyanines with adequate hydrophilicity have promising photophysical features to be considered as PSs for PDT or aPDT due to their highly intense absorption band in the near infrared range (600-800 $\mathrm{nm}$ region) and capacity to efficiently generate singlet oxygen..$^{274-276}$

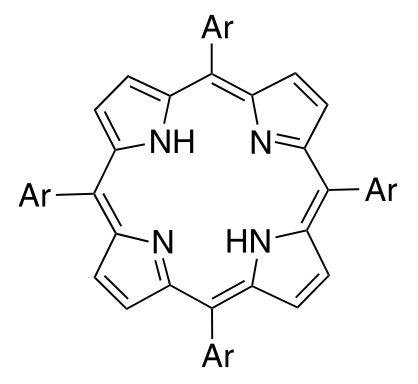<smiles>Cc1c(F)c(F)c(Sc2ccc(O)cc2)c(F)c1F</smiles>

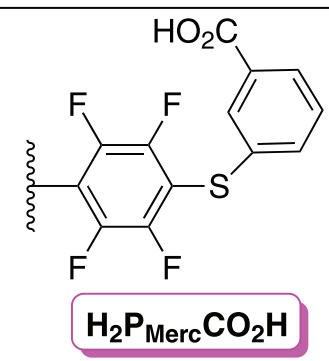<smiles>CC(C)c1ccc(C(=O)O)cc1</smiles>

$\mathrm{H}_{2} \mathrm{PCO}_{2} \mathrm{H}$

Figure 17. Structures of meso-tetraarylporphyrins $\mathrm{H}_{2} \mathrm{P}_{\text {Merc }} \mathrm{OH}, \mathrm{H}_{2} \mathrm{P}_{\text {Merc }} \mathrm{CO}_{2} \mathrm{H}$ and $\mathrm{H}_{2} \mathrm{PCO}_{2} \mathrm{H}$, bearing phenyl or pentafluorophenyl groups at the meso positions with or without acid groups used to prepare chitosan films. 
<smiles>N#Cc1ccc([N+](=O)[O-])cc1C#N</smiles><smiles>N#Cc1ccc(OC(=O)OCc2ccccc2)cc1C#N</smiles><smiles>[R]c1cc([R])c(C#N)cc1C#N</smiles>

Scheme 10. Synthetic access to phthalocyanine- $\beta$-cyclodextrin dyads $\beta$-CD-Pc1,2.

In 2006, considering that the important features of Pcs to be used as PSs are limited by their insolubility in physiological fluids, ${ }^{274-276}$ Ribeiro et al..$^{272,273}$ described for the first time the synthesis of the covalently linked $\beta$-cyclodextrin-Pcs dyads $\beta$-CD-Pc1 and $\beta$-CD-Pc2 (Scheme 10). These water-soluble dyads were prepared via a statistical cross condensation of a 4-( $\beta$-cyclodextrin)phthalonitrile with the adequate phthalonitriles $\left(\mathrm{R}=\mathrm{H}\right.$ or $\left.{ }^{t} \mathrm{OBu}\right)$.

In the same line of interest, ${ }^{272}$ the water-soluble non-symmetrical sugar-phthalocyanine 3 was

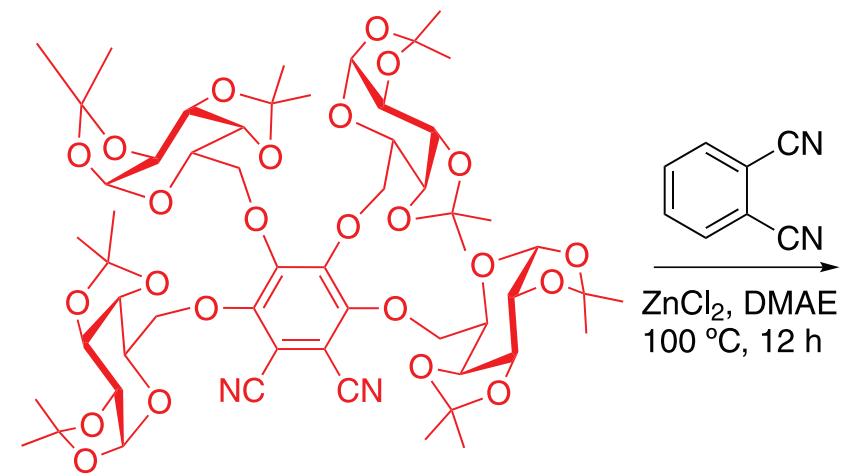

Phthal-1 prepared via a statistical cross-condensation of tetrakis(1,2:3,4-di- $O$-isopropylidene- $\alpha$-D-galactopyranose6-yl)phthalonitrile Phthal-1 with phthalonitrile (Scheme 11). The condensation was performed in the presence of $\mathrm{ZnCl}_{2}$ in $N, N$-dimethylethanolamine (DMAE) at $100^{\circ} \mathrm{C}$, followed by the removal of the sugar protecting groups with aqueous trifluoroacetic acid (TFA) and purification by reverse-phase column chromatography. The UV-Vis spectrum of the final dyad in dimethyl sulfoxide indicated the presence of monomeric species $\mathrm{ZnPc} 3-\mathrm{Gal}$, but in water the significant

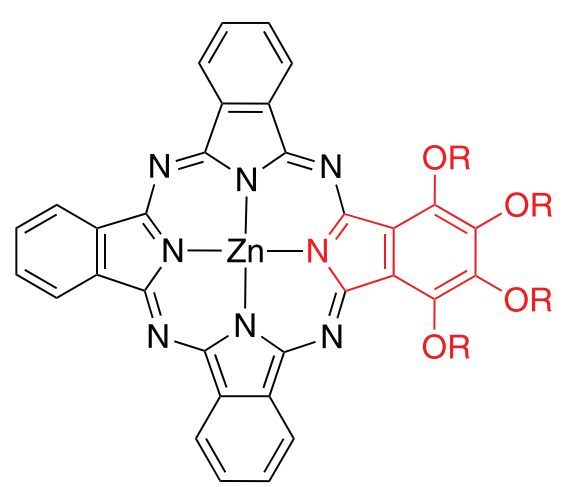

TFA/H ${ }_{2} \mathrm{O}$ (9:1), (ZnPc3-Galpro, $\mathrm{R}=$ GalPro

rt, 4 h. ZnPc3-Gal, R = Gal

Scheme 11. Synthetic access to the sugar-phthalocyanines. 
reduction in the Q-band suggested intermolecular aggregation due to macrocycle cofacial arrangements. Matrix-assisted laser desorption/ionization time-of-flight mass spectrometry (MALDI-TOF-MS) proved to be an excellent tool for systematically studying these kinds of systems, due to the difficulty of their characterization.

The studies discussed in this section are just a small portion of the successful studies developed between the Aveiro group and Brazilian researchers, e.g., from Universidade Federal Fluminense (RJ), Universidade Federal do Paraná (PR), Universidade Federal de Santa Maria (RS), Universidade Federal de São Carlos (SP), which started when one of us met Prof Yassuko Iamamoto from USP in Ribeirão Preto at the $7^{\text {th }}$ International Symposium on Dioxygen Activation and Homogeneous Catalytic Oxidation, York, Great-Britain, in 1999. So, we believe that Prof Iamamoto had an important role in the establishment of this network involving the porphyrin group of Aveiro led by Prof José Cavaleiro and other Brazilian groups.

\section{Final Remarks}

In this work, we reviewed the initial and more recent works using metalloporphyrins and analogues, mainly as catalysts in different chemical systems, since beginning at USP in Ribeirão Preto in the 1980s. Besides that, we also discussed some works that have resulted from the joint research effort between Brazilian researchers and Portuguese colleagues from Universidade de Aveiro working in the porphyrin field.

From this review, it is possible to infer that in the last 30 years the chemistry of porphyrins and other correlated macrocycle compounds has become a solid research area in Brazil, not only for catalysis but also for many other applications, such as antimicrobial and tumoral photodynamic therapy and sensors. However, there is still room for the design of new systems based on porphyrins and metalloporphyrins with improved features for special applications. In the catalytic context these important systems can be further explored to afford new therapeutic agents from cheap substrates (e.g., terpenes, steroids and others), under environmental benign conditions.

The ability of porphyrinic based catalytic systems to modulate the metabolic role of P-450 towards xenobiotic can be used as a powerful tool to predict which metabolites arise during biotransformation assays. Thus, it may be possible to develop systems to produce from drugs several metabolites in adequate amounts for further pharmacological and toxicological evaluation in order to reduce animal testing and the problems associated to the isolation of natural enzymes.

\section{Acknowledgments}

We are grateful for the financial support that enabled the results presented here, mainly from CAPES (this study was financed in part by the Coordenação de Aperfeiçoamento de Pessoal de Nível Superior-Brazil (CAPES)-Finance Code 001), CNPq (Conselho Nacional de Desenvolvimento Científico e Tecnológico), FAPESP (Fundação de Amparo à Pesquisa do Estado de São Paulo), Fundação Araucária and UFPR. Thanks are also due to the University of Aveiro and FCT/MEC for the financial support to QOPNA (FCT UID/QUI/00062/2019), and to the FCT project (FCT-PTDC/ASP-PES/29576/2017), through national founds and where applicable co-financed by the FEDEROperational Thematic Program for Competitiveness and Internationalization-COMPETE 2020, within the PT2020 Partnership Agreement. Thanks are also due to the Portuguese NMR and Mass Networks. K. A. D. F. Castro thanks CNPq for the post-doctoral grant (process 201107/2014-7) and PNPD/CAPES.

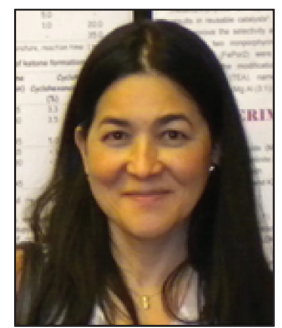

Shirley Nakagaki is Full Professor at the Chemistry Department of Universidade Federal do Paraná (UFPR). She graduated in Chemistry in 1985 at Universidade de São Paulo (FFCLUSP/RP). PhD Chemistry Institute UNESP/Araraquara-SP, under the supervision of Yassuko Iamamoto (1992). She is currently working on the preparation of solid catalysts efficient and selective for heterogeneous catalytic process based on metalloporphyrins. She has more than 100 publications and an H index of 30. She is CNPq researcher level $1 C$ and has supervised 6 Post-doctoral researchers, 12 PhD thesis, 20 $M S c$ dissertations and over more than 40 undergraduate projects (scientific initiation).

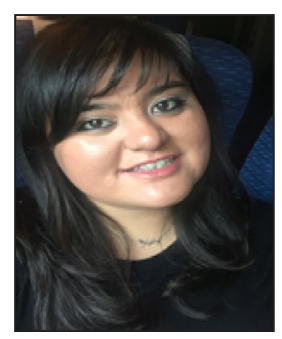

Kelly Aparecida Dias de Freitas Castro is graduated in Chemistry in 2008 at the Universidade Federal do Paraná (UFPR), Brazil, where she got her Master's degree, in 2009. In 2013, she received a $P h D$ degree in Chemistry at UFPR under the supervision of Prof Shirley Nakagaki. The work was developed partly at the University of Aveiro-Portugal (Chemistry Department/QOPNA Group). Pos-doctoral researcher at University of Aveiro in 2014. Presently, she is a Post-doctoral researcher in Brazil (School of Pharmaceutical Sciences of Ribeirão Pretol 
FCFRP/USP). Has experience in Chemistry, focusing on Bioinorganic chemistry, acting on the following subjects: porphyrin, epoxidation, oxidation, catalysis, nonheme complexes, chlorins, metalloporphyrins, immobilization/ encapsulation of porphyrin derivatives, catecholase, photocatalysis, photobiological and photophysical studies. She is the author/co-author of 29 papers published in international peer-reviewed journals and has an $H$ factor of 16.

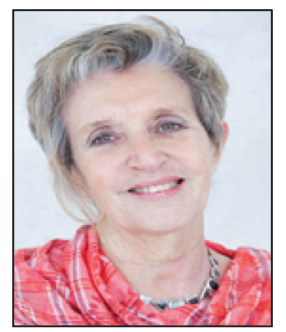

Maria da Graça P. M. S. Neves is Associate Professor with Habilitation in the Department of Chemistry at the University of Aveiro, Portugal. She obtained her Habilitation and PhD degree both at the University of Aveiro, her MSc degree at UMIST, Manchester, Great Britain, and her BSc degree in Chemistry at the University of Lourenço Marques, Mozambique. Her research interests are centered on the synthesis, functionalization, and potential applications in different fields (e.g., catalysis, photocatalysis, photodynamic therapy, sensors, dye sensitized solar cells) of tetrapyrrolic macrocycles like porphyrins, corroles and phthalocyanines. She has been in charge of the supervision of more than 50 final works of BSc and interns; $16 \mathrm{MSc}$ thesis concluded and $1 \mathrm{MSc}$ under development; 21 PhD Thesis concluded and 3 PhD undergoing and several Post-doctoral fellowships. She published more than 316 publications, 8 book chapters, 4 patents and has an $H$ factor of 42.

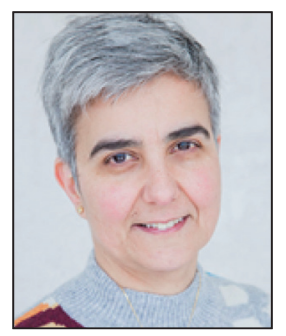

Maria do Amparo Faustino is since 2001 Assistant Professor at the Department of Chemistry $(D Q)$ of the University of Aveiro (UA). She got her PhD in Chemistry (Organic Chemistry) in 1999 under the supervision of Prof José A. S. Cavaleiro and Prof Maria da Graça P. M. S. Neves, University of Aveiro. She has been in charge of the supervision of more than 70 undergraduate students, 8 PhD students (3 concluded and 5 undergoing) and 37 MSc. Over the last years, her work was focused essentially on the synthesis, reactivity and characterization of tetrapyrrolic macrocycles with structural features to be considered as dyes in solar cells (DSSC) and in medical and environmental applications (photodynamic therapy of neoplastic tissues, microorganisms photoinactivation, dermatologic formulations). She was inventor of 1 patent and published 17 book chapters and 139 scientific papers in ISI journals. These scientific papers were cited around 3000 times in the Scopus search, corresponding to an $H$ factor of 32 .

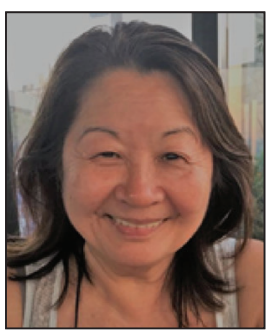

Yassuko Iamamoto is full professor at USP/Ribeirão Preto-SP. Graduated in Farmacy and Biochemistry in 1968 at Universidade Federal do Mato Grosso do Sul and she obtained her PhD degree at the Instituto de Química da Universidade de São Paulo (analytical chemistry). Her first Post-doctoral was at University of California-San Diego, in the chemistry of porphyrins and biomimetic catalysis under the supervision of Prof T. G. Traylor (1981). Her research interests are centered on bioinorganic chemistry acting on porphyrins and metaloporphyrins (MeP), MeP immobilized on mesoporous silica, biomimetic catalysis, oxidative metabolism of drugs, bioactive molecules and pesticides and synthesis of porphyrin derivatives for application on PDT. She is also active in chemical education research and university pedagogical studies. She has about 90 publications with $H$ factor of 26. She has been in charge of the supervision of more than 70 final works of scientific initiation, MSc, PhD thesis and Post-doctoral fellowships.

\section{References}

1. Garfinkel, D.; Arch. Biochem. Biophys. 1958, 77, 493.

2. Mitoma, C.; Posner, H. S.; Reitz, H. C.; Udenfriend, S.; Arch. Biochem. Biophys. 1956, 61, 431.

3. Klingenberg, M.; Arch. Biochem. Biophys. 1958, 75, 376.

4. Omura, T.; Sato, R.; J. Biol. Chem. 1962, 237, 1375.

5. Ortiz de Montellano, P. R.; Chem. Rev. 2010, 110, 932.

6. McQuarters, A. B.; Wolf, M. W.; Hunt, A. P.; Lehnert, N.; Angew. Chem., Int. Ed. 2014, 53, 4750.

7. Cook, L. P.; Brewer, G.; Wong-Ng, W.; Crystals 2017, 7, 223.

8. White, R. E.; Coon, M. J.; Annu. Rev. Biochem. 1980, 49, 315.

9. Guengerich, F. P.; Macdonald, T. L.; Acc. Chem. Res. 1984, 17, 9.

10. Nelson, S. D.; J. Med. Chem. 1982, 25, 753.

11. Groves, J. T.; McClusky, G. A. In Biochemical and Clinical Aspects of Oxygen; Caughey, W. S., ed.; Academic Press: New York, 1979.

12. Fish, R. H.; Kimmel, E. C.; Casida, J. E.; J. Organomet. Chem. 1976, 118, 41.

13. Egawa, T.; Shimada, H.; Ishimura, Y.; Biochem. Biophys. Res. Commun. 1994, 201, 1464.

14. Rittle, J.; Green, M. T.; Science 2010, 330, 933.

15. Rahimtula, A. D.; O’Brien, P. J.; Biochem. Biophys. Res. Commun. 1974, 60, 440. 
16. Nordblom, G. D.; White, R. E.; Coon, M. J.; Arch. Biochem. Biophys. 1976, 175, 524.

17. Hrycay, E. G.; Gustafsson, J.-Å.; Ingelman-Sundberg, M.; Ernster, L.; Biochem. Biophys. Res. Commun. 1975, 66, 209.

18. Lichtenberger, F.; Nastainczyk, W.; Ullrich, V.; Biochem. Biophys. Res. Commun. 1976, 70, 939.

19. Gustafsson, J. A.; Bergman, J.; FEBS Lett. 1976, 70, 276.

20. Zucca, P.; Neves, C. M. B.; Simões, M. M. Q.; Neves, M. D. G. P. M. S.; Cocco, G.; Sanjust, E.; Molecules 2016, 21, 964.

21. Groves, J. T.; Watanabe, Y.; J. Am. Chem. Soc. 1988, 110, 8443.

22. Hrycay, E. G.; Bandiera, S. M.; Arch. Biochem. Biophys. 2012 , $522,71$.

23. Cooper, H. L.; Groves, J. T.; Arch. Biochem. Biophys. 2011, 507, 111.

24. Yosca, T. H.; Rittle, J.; Krest, C. M.; Onderko, E. L.; Silakov, A.; Calixto, J. C.; Behan, R. K.; Green, M. T.; Science 2013, 342,825 .

25. Groves, J. T.; Nemo, T. E.; Myers, R. S.; J. Am. Chem. Soc. 1979, 101, 1032.

26. Mansuy, D.; Cron. Chim. 2007, 10, 392.

27. Castro, K. A. D. F.; Simões, M. M. Q.; Neves, M. G. P. M. S.; Cavaleiro, J. A. S.; Ribeiro, R. R.; Wypych, F.; Nakagaki, S.; Appl. Catal., A 2015, 503, 9.

28. Zardi, P.; Intrieri, D.; Caselli, A.; Gallo, E.; J. Organomet. Chem. 2012, 716, 269.

29. Fackler, P.; Huber, S. M.; Bach, T.; J. Am. Chem. Soc. 2012, $134,12869$.

30. Raoul, N.; Gallo, E.; Rose, E.; J. Porphyrins Phthalocyanines 2011, 15, 602 .

31. Han, Y.; Wu, Y.; Lai, W.; Cao, R. ; Inorg. Chem. 2015, 54, 5604.

32. Moghadam, M.; Tangestaninejad, S.; Mirkhani, V.; Mohammadpoor-Baltork, I.; Gharaati, S.; Appl. Organomet. Chem. 2009, 23, 446.

33. Araghi, M.; Mirkhani, V.; Moghadam, M.; Tangestaninejad, S.; Mohammdpoor-Baltork, I.; Dalton Trans. 2012, 41, 11745.

34. Assary, R. S.; Curtiss, L. A.; Dumesic, J. A.; ACS Catal. 2013, 3, 2694.

35. Konishi, K.; Makita, K.; Aida, T.; Inoue, S.; J. Chem. Soc., Chem. Commun.1988, 643.

36. Shibata, K.; Aida, T.; Inoue, S.; Tetrahedron Lett. 1992, 33, 1077.

37. Totten, R. K.; Kim, Y. S.; Weston, M. H.; Farha, O. K.; Hupp, J. T.; Nguyen, S. T.; J. Am. Chem. Soc. 2013, 135, 11720.

38. Groves, J.; F1000Research 2015, 4, 1.

39. Farrell, N.; Neves, A. A.; Inorg. Chim. Acta 1981, 54, L53.

40. Augusto, O.; Bechara, E. J. H.; Biochim. Biophys. Acta 1980, 631, 203.

41. Traylor, T. G.; Iamamoto, Y.; Nakano, T.; J. Am. Chem. Soc. 1986, 108, 3529.
42. Ortiz de Montellano, P. R.; Stearns, R. A.; J. Am. Chem. Soc. 1987, 109, 3415.

43. Groves, J. T. In Cytochrome P-450: Structure, Mechanism and Biochemistry, $3^{\text {rd }}$ ed.; Ortiz de Montellano, P. R., ed.; Plenum: New York, USA, 1986.

44. Groves, J. T.; Haushalter, R. C.; Nakamura, M.; Nemo, T. E.; Evans, B. J.; J. Am. Chem. Soc. 1981, 103, 2884.

45. Traylor, P. S.; Dolphin, D.; Traylor, T. G.; J. Chem. Soc., Chem. Commun.1984, 279.

46. Castellino, A. J.; Bruice, T. C.; J. Am. Chem. Soc. 1988, 110, 158.

47. Groves, J. T.; J. Inorg. Biochem. 2006, 100, 434.

48. Dolphin, D.; Traylor, T. G.; Xie, L. Y.; Acc. Chem. Res. 1997, $30,251$.

49. Simões, M. M. Q.; Neves, C. M. B.; Pires, S. M. G.; Neves, M. G. P. M. S.; Cavaleiro, J. A. S.; Pure Appl. Chem. 2013, 85, 1671.

50. Simões, M. M. Q.; de Paula, R.; Neves, M. G. P. M. S.; Cavaleiro, J. A. S.; J. Porphyrins Phthalocyanines 2009, 13, 589.

51. Meunier, B.; Chem. Rev. 1992, 92, 1411.

52. Rebelo, S. L. H.; Pereira, M. M.; Simões, M. M. Q.; Neves, M. G. P. M. S.; Cavaleiro, J. A. S.; J. Catal. 2005, 234, 76.

53. Smith, J. R. L. In Metalloporphyrins in Catalytic Oxidations, $1^{\text {st }}$ ed.; Sheldon, R. A., ed.; Marcel Dekker: New York, 1994.

54. Bell, S. R.; Groves, J. T.; J. Am. Chem. Soc. 2009, 131, 9640.

55. das Dores Assis, M.; Serra, O. A.; Iamamoto, Y.; Nascimento, O. R.; Inorg. Chim. Acta 1991, 187, 107.

56. Iamamoto, Y.; das Dores Assis, M.; Baffa, O.; Nakagaki, S.; Nascimento, O. R.; J. Inorg. Biochem. 1993, 52, 191.

57. Iamamoto, Y.; Serra, O. A.; Idemori, Y. M.; J. Inorg. Biochem. 1994, 54, 55.

58. Iamamoto, Y.; Assis, M. D.; Ciuffi, K. J.; Prado, C. M. C.; B. Z. Prellwitz, M. M.; Nascimento, O. R.; Sacco, H. C.; J. Mol. Catal. A: Chem. 1997, 116, 365.

59. de Sousa, A. N.; de Carvalho, M. E. M. D.; Idemori, Y. M.; J. Mol. Catal. A: Chem. 2001, 169, 1.

60. Castro, K. A. D. F.; Simões, M. M. Q.; Neves, M. G. P. M. S.; Cavaleiro, J. A. S.; Wypych, F.; Nakagaki, S.; Catal. Sci. Technol. 2014, 4, 129.

61. Iamamoto, Y.; Prado, C. M. C.; Sacco, H. C.; Ciuffi, K. J.; Assis, M. D.; Maestrin, A. P. J.; Melo, A. J. B.; Baffa, O.; Nascimento, O. R.; J. Mol. Catal. A: Chem. 1997, 117, 259.

62. Iamamoto, Y.; Assis, M. D.; Ciuffi, K. J.; Sacco, H. C.; Iwamoto, L.; Melo, A. J. B.; Nascimento, O. R.; Prado, C. M.; J. Mol. Catal. A: Chem. 1996, 109, 189.

63. Huang, G.; Mo, L.-Q.; Cai, J.-L.; Cao, X.; Peng, Y.; Guo, Y.-A.; Wei, S.-J.; Appl. Catal., B 2015, 162, 364.

64. Faria, A. L.; Mac Leod, T. O. C.; Barros, V. P.; Assis, M. D.; J. Braz. Chem. Soc. 2009, 20, 895.

65. Castro, K. A. D. F.; de Lima, F. H. C.; Simões, M. M. Q.; Neves, M. G. P. M. S.; Paz, F. A. A.; Mendes, R. F.; Nakagaki, S.; Cavaleiro, J. A. S.; Inorg. Chim. Acta 2017, 455, 575. 
66. Nam, W.; Acc. Chem. Res. 2007, 40, 522.

67. da Silva, V. S.; Vieira, W. C. D.; Meireles, A. M.; Ucoski, G. M.; Nakagaki, S.; Idemori, Y. M.; DeFreitas-Silva, G.; New J. Chem. 2017, 41, 997.

68. da Silva, V. S.; Nakagaki, S.; Ucoski, G. M.; Idemori, Y. M.; DeFreitas-Silva, G.; RSC Adv. 2015, 5, 106589.

69. de Freitas Silva, G.; da Silva, D. C.; Guimarães, A. S.; do Nascimento, E.; Rebouças, J. S.; de Araujo, M. P.; de Carvalho, M. E. M. D.; Idemori, Y. M.; J. Mol. Catal. A: Chem. 2007, 266, 274.

70. da Silva, V. S.; Teixeira, L. I.; do Nascimento, E.; Idemori, Y. M.; DeFreitas-Silva, G.; Appl. Catal., A 2014, 469, 124.

71. de Araujo Tôrres, M. G.; da Silva, V. S.; Idemori, Y. M.; DeFreitas-Silva, G.; Arabian J. Chem. 2017, DOI: 10.1016/j.arabjc.2017.12.007.

72. Martins, D. C. D.; Silva, F. C.; Meireles, A. M.; Soares, E. A. R.; Silva, G. D. F.; Vieira, S. A.; Duarte, L. P.; Rebouças, J. S.; Idemori, Y. M.; Catal. Commun. 2016, 86, 104.

73. Appleton, A. J.; Evans, S.; Smith, J. R. L.; J. Chem. Soc. Perkin Trans. 2 1996, 281.

74. Battioni, P.; Bartoli, J. F.; Mansuy, D.; Byun, Y. S.; Traylor, T. G.; J. Chem. Soc., Chem. Commun. 1992, 1051.

75. Guo, C. C.; Liu, X. Q.; Liu, Q.; Liu, Y.; Chu, M. F.; Lin, W. Y.; J. Porphyrins Phthalocyanines 2009, 13, 1250.

76. Ucoski, G. M.; Castro, K. A. D. F.; Ciuffi, K. J.; Ricci, G. P.; Marques, J. A.; Nunes, F. S.; Nakagaki, S.; Appl. Catal., A 2011, 404, 120.

77. Barona-Castano, J. C.; Carmona-Vargas, C. C.; Brocksom, T. J.; de Oliveira, K. T.; Molecules 2016, 21, 310.

78. https://www.porphychem.com, accessed in January 2019.

79. Iamamoto, Y.; Idemori, Y. M.; Nakagaki, S. J. Mol. Catal. A: Chem. 1995, 99, 187.

80. Ferreira, G. K. B.; Castro, K. A. D. F. C.; Machado, G. S.; Ribeiro, R. R.; Ciuffi, K. J.; Ricci, G. P.; Marques, J. A.; Nakagaki, S.; J. Mol. Catal. A: Chem. 2013, 378, 263.

81. Papacídero, A. T.; Rocha, L. A.; Caetano, B. L.; Molina, E.; Sacco, H. C.; Nassar, E. J.; Martinelli, Y.; Mello, C.; Nakagaki, S.; Ciuffi, K.; Colloids Surf., A 2006, 275, 27.

82. Nakagaki, S.; Ferreira, G. K. B.; Marcalb, A. L.; Ciuffi, K. J.; Curr. Org. Synth. 2014, 11, 67.

83. Castro, K. A. D. F.; Halma, M.; Machado, G. S.; Ricci, G. P.; Ucoski, G. M.; Ciuffi, K. J.; Nakagaki, S.; J. Braz. Chem. Soc. 2010, 21, 1329.

84. Castro, K. A. D. F.; Pires, S. M. G.; Ribeiro, M. A.; Simões, M. M. Q.; Neves, M. G. P. M. S.; Schreiner, W. H.; Wypych, F.; Cavaleiro, J. A. S.; Nakagaki, S.; J. Colloid Interface Sci. 2015, 450, 339.

85. Pinto, V. H. A.; Rebouças, J. S.; Ucoski, G. M.; de Faria, E. H.; Ferreira, B. F.; Silva San Gil, R. A.; Nakagaki, S.; Appl. Catal., A 2016, 526, 9.

86. Ucoski, G. M.; Pinto, V. H. A.; DeFreitas-Silva, G.; Rebouças,
J. S.; Mazzaro, I.; Nunes, F. S.; Nakagaki, S.; ChemistrySelect 2017, 2, 3703.

87. Ucoski, G. M.; Pinto, V. H. A.; DeFreitas-Silva, G.; Rebouças, J. S.; Marcos da Silva, R.; Mazzaro, I.; Nunes, F. S.; Nakagaki, S.; Microporous Mesoporous Mater. 2018, 265, 84.

88. Zanardi, F. B.; Barbosa, I. A.; de Sousa, P. C.; Zanatta, L. D.; da Silva, D. L.; Serra, O. A.; Iamamoto, Y.; Microporous Mesoporous Mater. 2016, 219, 161.

89. Bolzon, L. B.; Airoldi, H. R.; Zanardi, F. B.; Granado, J. G.; Iamamoto, Y.; Microporous Mesoporous Mater. 2013, 168, 37.

90. DeOliveira, E.; Neri, C. R.; Ribeiro, A. O.; Garcia, V. S.; Costa, L. L.; Moura, A. O.; Prado, A. G.; Serra, O. A.; Iamamoto, Y.; J. Colloid Interface Sci. 2008, 323, 98.

91. Zanatta, L. D.; Barbosa, I. A.; Zanardi, F. B.; de Sousa Filho, P. C.; Bolzon, L. B.; Ramos, A. P.; Serra, O. A.; Iamamoto, Y.; RSC Adv. 2016, 6, 104886.

92. Ucoski, G. M.; Machado, G. S.; Silva, G. F.; Nunes, F. S.; Wypych, F.; Nakagaki, S.; J. Mol. Catal. A: Chem. 2015, 408, 123.

93. Henriques, C. A.; Fernandes, A.; Rossi, L. M.; Ribeiro, M. F.; Calvete, M. J. F.; Pereira, M. M.; Adv. Funct. Mater. 2016, 26, 3359.

94. Barbosa, I. A.; de Sousa Filho, P. C.; da Silva, D. L.; Zanardi, F. B.; Zanatta, L. D.; de Oliveira, A. J. A.; Serra, O. A.; Iamamoto, Y.; J. Colloid Interface Sci. 2016, 469, 296.

95. Vinhado, F. S.; Martins, P. R.; Masson, A. P.; Abreu, D. G.; Vidoto, E. A.; Nascimento, O. R.; Iamamoto, Y.; J. Mol. Catal. A: Chem. 2002, 188, 141.

96. Schiavon, M. A.; Iamamoto, Y.; Nascimento, O. R.; Assis, M. D.; J. Mol. Catal. A: Chem. 2001, 174, 213.

97. Doro, F. G.; Smith, J. R. L.; Ferreira, A. G.; Assis, M. D.; J. Mol. Catal. A: Chem. 2000, 164, 97.

98. Iamamoto, Y.; Ciuffi, K. J.; Sacco, H. C.; Iwamoto, L. S.; Nascimento, O. R.; Prado, C. M. C.; J. Mol. Catal. A: Chem. 1997, 116, 405.

99. Nakagaki, S.; Xavier, C. R.; Wosniak, A. J.; Mangrich, A. S.; Wypych, F.; Cantão, M. P.; Denicoló, I.; Kubota, L. T.; Colloids Surf., A 2000, 168, 261.

100. Rosa, I. L. V.; Manso, C. M. C. P.; Serra, O. A.; Iamamoto, Y.; J. Mol. Catal. A: Chem. 2000, 160, 199.

101. Skrobot, F. C.; Rosa, I. L. V.; Marques, A. P. A.; Martins, P. R.; Rocha, J.; Valente, A. A.; Iamamoto, Y.; J. Mol. Catal. A: Chem. 2005, 237, 86 .

102. Nakagaki, S.; Ramos, A. R.; Benedito, F. L.; Peralta-Zamora, P. G.; Zarbin, A. J. G.; J. Mol. Catal. A: Chem. 2002, 185, 203.

103. Machado, A. M.; Wypych, F.; Drechsel, S. M.; Nakagaki, S.; J. Colloid Interface Sci. 2002, 254, 158.

104. Bizaia, N.; de Faria, E. H.; Ricci, G. P.; Calefi, P. S.; Nassar, E. J.; Castro, K. A. D. F.; Nakagaki, S.; Ciuffi, K. J.; Trujillano, R.; Vicente, M. A.; Gil, A.; Korili, S. A.; ACS Appl. Mater. Interfaces 2009, 1, 2667. 
105. Lovo de Carvalho, A.; Ferreira, B. F.; Martins, C. H. G.; Nassar, E. J.; Nakagaki, S.; Machado, G. S.; Rives, V.; Trujillano, R.; Vicente, M. A.; Gil, A.; Korili, S. A.; de Faria, E. H.; Ciuffi, K. J.; J. Phys. Chem. C 2014, 118, 24562.

106. Nakagaki, S.; Benedito, F. L.; Wypych, F.; J. Mol. Catal. A: Chem. 2004, 217, 121.

107. Machado, G. S.; Ucoski, G. M.; Lima, O. J.; Ciuffi, K. J.; Wypych, F.; Nakagaki, S.; Appl. Catal., A 2013, 460-461, 124.

108. Machado, G. S.; Castro, K. A. D. F.; Wypych, F.; Nakagaki, S.; J. Mol. Catal. A: Chem. 2008, 283, 99.

109. Nakagaki, S.; Castro, K. A. D. F.; Machado, G. S.; Halma, M.; Drechsel, S. M.; Wypych, F.; J. Braz. Chem. Soc. 2006, 17, 1672.

110. Machado, G. S.; Groszewicz, P. B.; Castro, K. A. D. F.; Wypych, F.; Nakagaki, S.; J. Colloid Interface Sci. 2012, 374, 278.

111. Machado, G. S.; Lima, O. J.; Ciuffi, K. J.; Wypych, F.; Nakagaki, S.; Catal. Sci. Technol. 2013, 3, 1094.

112. Crepaldi, E. L.; Valim, J. B.; Quim. Nova 1998, 21, 300.

113. de Faria, A. L.; Airoldi, C.; Doro, F. G.; Fonseca, M. G.; Assis, M. D.; Appl. Catal., A 2004, 268, 217.

114. Nakagaki, S.; Mangrich, A. S.; Wypych, F.; Inorg. Chim. Acta 1997, 254, 213.

115. Nakagaki, S.; Mantovani, K. M.; Machado, G. S.; Castro, K. A. D. F.; Wypych, F.; Molecules 2016, 21, 291.

116. Halma, M.; Wypych, F.; Drechsel, S. M.; Nakagaki, S.; J. Porphyrins Phthalocyanines 2002, 6, 502.

117. Wypych, F.; Bubniak, G. A.; Halma, M.; Nakagaki, S.; J. Colloid Interface Sci. 2003, 264, 203.

118. Castro, K. A. D. F.; Wypych, F.; Antonangelo, A.; Mantovani, K. M.; Bail, A.; Ucoski, G. M.; Ciuffi, K. J.; Cintra, T. E.; Nakagaki, S.; J. Colloid Interface Sci. 2016, 478, 374.

119. Castro, K. A. D. F.; Bail, A.; Groszewicz, P. B.; Machado, G. S.; Schreiner, W. H.; Wypych, F.; Nakagaki, S.; Appl. Catal., A 2010, 386, 51.

120. Halma, M.; Castro, K. A. D. F.; Taviot-Gueho, C.; Prevot, V.; Forano, C.; Wypych, F.; Nakagaki, S.; J. Catal. 2008, 257, 233.

121. Machado, G. S.; Arízaga, G. G. C.; Wypych, F.; Nakagaki, S.; J. Catal. 2010, 274, 130.

122. Machado, G. S.; Wypych, F.; Nakagaki, S.; Appl. Catal., A 2012, 413-414, 94

123. Mantovani, K. M.; Stival, J. F.; Wypych, F.; Bach, L.; Peralta Zamora, P. G.; Rocco, M. L.; Nakagaki, S.; J. Catal. 2017, 352, 442.

124. Maruyama, S. A.; Westrup, K. C. M.; Nakagaki, S.; Wypych, F.; Appl. Clay Sci. 2017, 139, 108.

125. Halma, M.; Castro, K. A. D. F.; Prevot, V.; Forano, C.; Wypych, F.; Nakagaki, S.; J. Mol. Catal. A: Chem. 2009, 310, 42.

126. Nakagaki, S.; Castro, K. A. D. F.; Ucoski, G. M.; Halma, M.; Prevot, V.; Forano, C.; Wypych, F.; J. Braz. Chem. Soc. 2014, 25,2329
127. Nakagaki, S.; Halma, M.; Bail, A.; Arizaga, G. G.; Wypych, F.; J. Colloid Interface Sci. 2005, 281, 417.

128. Wypych, F.; Bail, A.; Halma, M.; Nakagaki, S.; J. Catal. 2005, $234,431$.

129. Mantovani, K. M.; Westrup, K. C. M.; da Silva Jr., R. M.; Jaerger, S.; Wypych, F.; Nakagaki, S.; Dalton Trans. 2018, 47, 3068.

130. Saltarelli, M.; de Faria, E. H.; Ciuffi, K. J.; Nassar, E. J.; Trujillano, R.; Rives, V.; Vicente, M. A.; Mol. Catal. 2019, 462, 114.

131. Machado, G. S.; Castro, K. A. D. F.; de Lima, O. J.; Nassar, E. J.; Ciuffi, K. J.; Nakagaki, S.; Colloids Surf., A 2009, 349, 162.

132. Ribeiro, V. G. P.; Marcelo, A. M. P.; da Silva, K. T.; da Silva, F. L. F.; Mota, J. P. F.; do Nascimento, J. P. C.; Sombra, A. S. B.; Clemente, C. D. S.; Mele, G.; Carbone, L.; Mazzetto, S. E.; Materials 2017, 10, 1114.

133. Machado, G. S.; Wypych, F.; Nakagaki, S.; J. Colloid Interface Sci. 2012, 377, 379.

134. Vasapollo, G.; Mele, G.; Sole, R. D.; Pio, I.; Li, J.; Mazzetto, S. E.; Molecules 2011, 16, 5769.

135. Wong, A.; Sotomayor, M. D. T.; Sens. Actuators, B 2013, 181, 332.

136. Safar, G. A. M.; Barros, W. P.; Idemori, Y. M.; CarvalhoDa-Silva, D.; Mendes, J. B. S.; Sinnecker, E. H. C. P.; Rebouças, J. S.; Stumpf, H. O.; J. Nanopart. Res. 2012, 14, 912.

137. Luz, R. C. S.; Damos, F. S.; Tanaka, A. A.; Kubota, L. T.; Gushikem, Y.; Talanta 2008, 76, 1097.

138. Gotardoa, M. C. A. F.; Guedes, A. A.; Schiavon, M. A.; José, N. A.; Valeria, I.; Yoshida, P.; Assis, M. D.; J. Mol. Catal. A: Chem. 2005, 229, 137.

139. Castro, K. A. D. F.; Moura, N. M. M.; Fernandes, A.; Faustino, M. A. F.; Simões, M. M. Q.; Cavaleiro, J. A. S.; Nakagaki, S.; Almeida, A.; Cunha, Â.; Silvestre, A. J. D.; Freire, C. S. R.; Pinto, R. J. B.; Neves, M. G. P. M. S.; Dyes Pigm. 2017, 137, 265.

140. Suslick, K. S.; Bhyrappa, P.; Chou, J. H.; Kosal, M. E.; Nakagaki, S.; Smithenry, D. W.; Wilson, S. R.; Acc. Chem. Res. 2005, 38, 283.

141. Smithenry, D. W.; Wilson, S. R.; Nakagaki, S.; Suslick, K. S.; J. Porphyrins Phthalocyanines 2017, 21, 857.

142. Drain, C. M.; Varotto, A.; Radivojevic, I.; Chem. Rev. 2009, $109,1630$.

143. Gao, W. Y.; Chrzanowski, M.; Ma, S.; Chem. Soc. Rev. 2014, $43,5841$.

144. Rowsell, J. L. C.; Yaghi, O. M.; Microporous Mesoporous Mater. 2004, 73, 3 .

145. Castro, K. A. D. F.; Figueira, F.; Mendes, R. F.; Cavaleiro, J. A. S.; Neves, M. G. P. M. S.; Simões, M. M. Q.; Paz, F. A. A.; Tomé, J. P. C.; Nakagaki, S.; ChemCatChem 2017, 9, 2939.

146. Castro, K. A. D. F.; Figueira, F.; Mendes, R. F.; Almeida Paz, F. A.; Neves, M. G. P. M. S.; Cavaleiro, J. A. S.; Nakagaki, S.; Tomé, J. P. C.; Simões, M. M. Q.; Polyhedron 2019, 158, 478. 
147. Antonangelo, A. R.; Grazia Bezzu, C.; McKeown, N. B.; Nakagaki, S.; J. Catal. 2019, 369, 133.

148. Ding, X.; Guo, J.; Feng, X.; Honsho, Y.; Guo, J.; Seki, S.; Maitarad, P.; Saeki, A.; Nagase, S.; Jiang, D.; Angew. Chem., Int. Ed. 2011, 50, 1289.

149. Kaur, P.; Hupp, J. T.; Nguyen, S. T.; ACS Catal. 2011, 1, 819.

150. Shultz, A. M.; Farha, O. K.; Hupp, J. T.; Nguyen, S. T.; Chem. Sci. 2011, 2, 686.

151. McKeown, N. B.; Hanif, S.; Msayib, K.; Tattershall, C. E.; Budd, P. M.; Chem. Commun. 2002, 2782.

152. Chen, L.; Yang, Y.; Jiang, D.; J. Am. Chem. Soc. 2010, 132, 9138.

153. Oveisi, A. R.; Zhang, K.; Khorramabadi-zad, A.; Farha, O. K.; Hupp, J. T.; Sci. Rep. 2015, 5, 10621.

154. Budd, P. M.; McKeown, N. B.; Polym. Chem. 2010, 1, 63.

155. McKeown, N. B.; Budd, P. M.; Chem. Soc. Rev. 2006, 35, 675.

156. Mackintosh, H. J.; Budd, P. M.; McKeown, N. B.; J. Mater. Chem. 2008, 18, 573.

157. Ciuffi, K. J.; Sacco, H. C.; Valim, J. B.; Manso, C. M. C. P.; Serra, O. A.; Nascimento, O. R.; Vidoto, E. A.; Iamamoto, Y.; J. Non-Cryst. Solids 1999, 247, 146.

158. Ciuffi, K. J.; Sacco, H. C.; Biazzotto, J. C.; Vidoto, E. A.; Nascimento, O. R.; Leite, C. A. P.; Serra, O. A.; Iamamoto, Y.; J. Non-Cryst. Solids 2000, 273, 100.

159. Battioni, P.; Cardin, E.; Louloudi, M.; Schöllhorn, B.; Spyroulias, G. A.; Mansuy, D.; Traylor, T. G.; Chem. Commun. 1996, 2037.

160. de Oliveira, D. C.; Sacco, H. C.; Nascimento, O. R.; Iamamoto, Y.; Ciuffi, K. J.; J. Non-Cryst. Solids 2001, 284, 27.

161. Sacco, H. C.; Ciuffi, K. J.; Biazzotto, J. C.; Mello, C.; de Oliveira, D. C.; Vidoto, E. A.; Nascimento, O. R.; Serra, O. A.; Iamamoto, Y.; J. Non-Cryst. Solids 2001, 284, 174.

162. Vidoto, E. A.; Moreira, M. S. M.; Vinhado, F. S.; Ciuffi, K. J.; Nascimento, O. R.; Iamamoto, Y.; J. Non-Cryst. Solids 2002, 304, 151.

163. Biazzotto, J. C.; Sacco, H. C.; Ciuffi, K. J.; Neri, C. R.; Ferreira, A. G.; Iamamoto, Y.; Serra, O. A.; J. Non-Cryst. Solids 1999, 247, 134.

164. Benedito, F. L.; Nakagaki, S.; Saczk, A. A.; Peralta-Zamora, P. G.; Costa, C. M. M.; Appl. Catal., A 2003, 250, 1.

165. Iamamoto, Y.; Ciuffi, K. J.; Sacco, H. C.; Prado, C. M. C.; de Moraes, M.; Nascimento, O. R.; J. Mol. Catal. 1994, 88, 167.

166. Moreira, M. S. M.; Martins, P. R.; Curi, R. B.; Nascimento, O. R.; Iamamoto, Y.; J. Mol. Catal. A: Chem. 2005, 233, 73.

167. Battioni, P.; Lallier, J.-P.; Barloy, L.; Mansuy, D.; J. Chem. Soc., Chem. Commun. 1989, 1149.

168. Martinez-Lorente, M. A.; Battioni, P.; Kleemiss, W.; Bartoli, J. F.; Mansuy, D.; J. Mol. Catal. A: Chem. 1996, 113, 343.

169. Sacco, H. C.; Iamamoto, Y.; Lindsay Smith, J. R.; J. Chem. Soc., Perkin Trans. 2 2001, 181.
170. Leal, O.; Anderson, D. L.; Bowman, R. G.; Basolo, F.; Burwell, R. L.; J. Am. Chem. Soc. 1975, 97, 5125.

171. das Dores Assis, M.; Smith, J. R. L.; J. Chem. Soc., Perkin Trans. 2 1998, 2221.

172. De Vos, D. E.; Dams, M.; Sels, B. F.; Jacobs, P. A.; Chem. Rev. 2002, 102, 3615.

173. Bedioui, F.; Coord. Chem. Rev. 1995, 144, 39.

174. Cooke, P. R.; Smith, J. R. L.; J. Chem. Soc. Perkin Trans. 1 1994, 1913.

175. Gilmartin, C.; Smith, J. R. L.; J. Chem. Soc. Perkin Trans. 2 1995, 243.

177. de Roy, A.; Forano, C.; Malki, K. E.; Besse, J.-P. In Expanded Clays and Others Micropourous Solids, $2^{\text {nd }}$ ed.; Occelli, M. L.; Robson, H., eds.; Springer: New York, USA, 1992.

178. Carbajal Arizaga, G. G.; Satyanarayana, K. G.; Wypych, F.; Solid State Ionics 2007, 178, 1143.

179. Henrist, C.; Traina, K.; Hubert, C.; Toussaint, G.; Rulmont, A.; Cloots, R.; J. Cryst. Growth 2003, 254, 176.

180. Arizaga, G. G. C.; Mangrich, A. S.; Gardolinski, J. E. F. D. C.; Wypych, F.; J. Colloid Interface Sci. 2008, 320, 168.

181. Kozawa, T.; Onda, A.; Yanagisawa, K.; Kishi, A.; Masuda, Y.; J. Solid State Chem. 2011, 184, 589.

182. Garcia-Martinez, O.; Vila, E.; Martin de Vidales, J. L.; Rojas, R. M.; Petrov, K.; J. Mater. Sci. 1994, 29, 5429.

183. Gardolinski, J. E.; Martins, H. P.; Wypych, F.; Quim. Nova 2003, $26,30$.

184. Joussein, E.; Petit, S.; Churchman, J.; Theng, B.; Righi, D.; Delvaux, B.; Clay Miner. 2005, 40, 383.

185. Coelho, A. C. V.; Santos, P. S.; Santos, H. S.; Quim. Nova 2007, 30, 146.

186. Molinari, A.; Amadelli, R.; Antolini, L.; Maldotti, A.; Battioni, P.; Mansuy, D.; J. Mol. Catal. A: Chem. 2000, 158, 521.

187. Yang, W.-J.; Guo, C.-C.; Li, Z.-Y.; Tao, N.-Y.; J. Porphyrins Phthalocyanines 2009, 13, 973.

188. Lee, Y.; Choi, J. H.; Jeon, H. J.; Choi, K. M.; Lee, J. W.; Kang, J. K.; Energy Environ. Sci. 2011, 4, 914.

189. Jiménez De Haro, M. C.; Martínez Blanes, J. M.; Poyato, J.; Pérez-Maqueda, L. A.; Lerf, A.; Pérez-Rodríguez, J. L.; J. Phys. Chem. Solids 2004, 65, 435.

190. Song, J.; Leng, M.; Xiao, H.; Zhang, L.; Qin, Y.; Hou, W.; Du, N.; Liu, J.; J. Nanosci. Nanotechnol. 2014, 14, 4649.

191. Zeng, H. Y.; Deng, X.; Wang, Y. J.; Liao, K. B.; AIChE J. 2009, $55,1229$.

192. Castro, K. A. D. F.; Silva, S.; Pereira, P. M. R.; Simões, M. M. Q.; Neves, M. G. P. M. S.; Cavaleiro, J. A. S.; Wypych, F.; Tomé, J. P. C.; Nakagaki, S.; Inorg. Chem. 2015, 54, 4382.

193. Pereira, C. F.; Figueira, F.; Mendes, R. F.; Rocha, J.; Hupp, J. T.; Farha, O. K.; Simões, M. M. Q.; Tomé, J. P. C.; Paz, F. A. A.; Inorg. Chem. 2018, 57, 3855.

194. Modak, A.; Mondal, J.; Bhaumik, A.; Appl. Catal., A 2013, 459, 41. 
195. Raja, R.; Sankar, G.; Thomas, J. M.; Angew. Chem., Int. Ed. 2000, 39, 2313.

196. Thomas, J. M.; Raja, R.; Sankar, G.; Bell, R. G.; Acc. Chem. Res. 2001, 34, 191.

197. Hartwig, J. F.; Larsen, M. A.; ACS Cent. Sci. 2016, 2, 281.

198. Shilov, A. E.; Shul'pin, G. B.; Chem. Rev. 1997, 97, 2879.

199. Dias, S. S. P.; Kirillova, M. V.; André, V.; Kłak, J.; Kirillov, A. M.; Inorg. Chem. Front. 2015, 2, 525.

200. Cook, B. R.; Reinert, T. J.; Suslick, K. S.; J. Am. Chem. Soc. 1986, 108, 7281.

201. Philipse, A. P.; van Bruggen, M. P. B.; Pathmamanoharan, C.; Langmuir 1994, 10, 92.

202. Rossi, L. M.; Vono, L. L. R.; Silva, F. P.; Kiyohara, P. K.; Duarte, E. L.; Matos, J. R.; Appl. Catal., A 2007, 330, 139.

203. Rossi, L. M.; Garcia, M. A. S.; Vono, L. L. R.; J. Braz. Chem. Soc. 2012, 23, 1959.

204. Jacinto, M. J.; Kiyohara, P. K.; Masunaga, S. H.; Jardim, R. F.; Rossi, L. M.; Appl. Catal., A 2008, 338, 52.

205. Zhao, D.; Feng, J.; Huo, Q.; Melosh, N.; Fredrickson, G. H.; Chmelka, B. F.; Stucky, G. D.; Science 1998, 279, 548.

206. Núñez, C.; Diniz, M.; dos Santos, A. A.; Capelo, J. L.; Lodeiro, C.; Dyes Pigm. 2014, 101, 156.

207. Fernandez-Lodeiro, J.; Nunez, C.; Lodeiro, A. F.; Oliveira, E.; Rodriguez-Gonzalez, B.; dos Santos, A. A.; Capelo, J. L.; Lodeiro, C.; J. Nanopart. Res. 2014, 16, 1.

208. Gonçalves, A. C.; Capelo, J. L.; Lodeiro, C.; Santos, A. A. D.; Sens. Actuators, B 2017, 239, 311.

209. Neves, P.; Nogueira, L. S.; Valente, A. A.; Pillinger, M.; Gonçalves, I. S.; Sampaio-Dias, I. E.; Sousa, C. A. D.; RizzoAguiar, F.; Rodríguez-Borges, J. E.; J. Organomet. Chem. 2018, $858,29$.

210. Dias, L. D.; Batista de Carvalho, A. L. M.; Pinto, S. M. A.; Aquino, G. L. B.; Calvete, M. J. F.; Rossi, L. M.; Marques, M. P. M.; Pereira, M. M.; Molecules 2018, 24, 52.

211. Dias, L. D.; Carrilho, R. M. B.; Henriques, C. A.; Piccirillo, G.; Fernandes, A.; Rossi, L. M.; Ribeiro, M. F.; Calvete, M. J. F.; Pereira, M. M.; J. Porphyrins Phthalocyanines 2018, 22, 331.

212. Ramos, C. I. V.; Figueira, F.; Poleto, M. D.; Amado, F. M. L.; Verli, H.; Tomé, J. P. C.; Neves, M. G. P. M. S.; J. Mass Spectrom. 2016, 51, 342.

213. CarvalhoDa-Silva, D.; Mac Leod, T. C. O.; de Faria, A. L.; dos Santos, J. S.; de Carvalho, M. E. M. D.; Rebouças, J. S.; Idemori, Y. M.; Assis, M. D.; Appl. Catal., A 2011, 408, 25.

214. Silva, M. C.; Correa, A. D.; Amorim, M. T. S. P.; Parpot, P.; Torres, J. A.; Chagas, P. M. B.; J. Mol. Catal. B: Enzym. 2012, $77,9$.

215. Martin, C. S.; Gouveia-Caridade, C.; Crespilho, F. N.; Constantino, C. J. L.; Brett, C. M. A.; J. Phys. Chem. C 2016, 120, 15698.

216. Figueira, E. C.; Ruy, M. R. S.; Wong, A.; Gonçalves, L. M.; Sotomayor, M. D. T.; Anal. Lett. 2018, 51, 1694.
217. Silva, E. M. P.; Serra, V. V.; Ribeiro, A. O.; Tomé, J. P. C.; Domingues, P.; Faustino, M. A. F.; Neves, M. G. P. M. S.; Tomé, A. C.; Cavaleiro, J. A. S.; Ferrer-Correia, A. J.; Iamamoto, Y.; Domingues, M. R. M.; Rapid Commun. Mass Spectrom. 2006, 20,3605 .

218. Iglesias, B. A.; Barata, J. F. B.; Domingues, M. R. M.; Neves, M. G. P. M. S.; Cavaleiro, J. A. S.; Int. J. Mass Spectrom. 2014, 363,1 .

219. Iglesias, B. A.; Barata, J. F. B.; Ramos, C. I. V.; SantanaMarques, M. G.; Neves, M. G. P. M. S.; Cavaleiro, J. A. S.; RSC Adv. 2014, 4, 16824.

220. Menezes, J. C. J. M. D. S.; Neves, M. G. P. M. S.; Cavaleiro, J. A. S.; Barros, C.; Santos, S. M.; da Silva, F. C.; Ferreira, V. F.; Domingues, M. R. M.; Int. J. Mass Spectrom. 2013, 343-344, 1.

221. Campos, V. R.; Gomes, A. T. P. C.; Cunha, A. C.; Neves, M. G. P. M. S.; Ferreira, V. F.; Cavaleiro, J. A. S.; Beilstein J. Org. Chem. 2017, 13, 195.

222. Cunha, A. C.; Gomes, A. T. P. C.; Ferreira, V. F.; de Souza, M. C. B. V.; Neves, M. G. P. M. S.; Tomé, A. C.; Silva, A. M. S.; Cavaleiro, J. A. S.; Synthesis 2010, 2010, 510.

223. Gomes, A. T. P. C.; Leão, R. A. C.; Alonso, C. M. A.; Neves, M. G. P. M. S.; Faustino, M. A. F.; Tomé, A. C.; Silva, A. M. S.; Pinheiro, S.; de Souza, M. C. B. V.; Ferreira, V. F.; Cavaleiro, J. A. S.; Helv. Chim. Acta 2008, 91, 2270.

224. Gomes, A. T. P. C.; Cunha, A. C.; Domingues, M. D. M.; Neves, M. G. P. M. S.; Tomé, A. C.; Silva, A. M. S.; Santos, F. D.; Souza, M. C. B. V.; Ferreira, V. F.; Cavaleiro, J. A. S.; Tetrahedron 2011, 67, 7336.

225. Forezi, L. D. M.; Gomes, A. T. P. C.; Neves, M. G. P. M. S.; Ferreira, V. F.; Boechat, F. D. S.; de Souza, M. C. B. V.; Cavaleiro, J. A. S.; Eur. J. Org. Chem. 2015, 5909.

226. Gomes, A. T. P. C.; Forezi, L. D. M.; Simões, M. M. Q.; Gonzaga, D. T.; Cardoso, M. F. C.; Da Silva, F. D.; Neves, M. G. P. M. S.; Ferreira, V. F.; Cavaleiro, J. A. S.; Synthesis-Stuttgart 2018, 50, 2678.

227. Menezes, J. C. J. M. D. S.; Faustino, M. A. F.; de Oliveira, K. T.; Uliana, M. P.; Ferreira, V. F.; Hackbarth, S.; Röder, B.; Teixeira Tasso, T.; Furuyama, T.; Kobayashi, N.; Silva, A. M. S.; Neves, M. G. P. M. S.; Cavaleiro, J. A. S.; Chemistry 2014, 20, 13644.

228. Gomes, A. T. P. C.; Leão, R. A. C.; da Silva, F. C.; Neves, M. G. P. M. S.; Faustino, M. A. F.; Tomé, A. C.; Silva, A. M. S.; Pinheiro, S.; de Souza, M. C. B. V.; Ferreira, V. F.; Cavaleiro, J. A. S.; J. Porphyrins Phthalocyanines 2009, 13, 247.

229. Menezes, J. C. J. M. D. S.; Gomes, A. T. P. C.; Silva, A.; Faustino, M. A. F.; Neves, M. G. P. M. S.; Tomé, A. C.; da Silva, F. C.; Ferreira, V. F.; Cavaleiro, J. A. S.; Synlett 2011, 2011, 1841.

230. Gomes, A. T. P. C.; Almeida Paz, F. A.; Neves, M. G. P. M. S.; Tomé, A. C.; Silva, A. M. S.; de Souza, M. C. B. V.; Ferreira, V. F.; Cavaleiro, J. A. S.; Tetrahedron Lett. 2011, 52, 4741. 
231. Cardoso, M. F. D. C.; Gomes, A. T. P. C.; Silva, V. L. M.; Silva, A. M. S.; Neves, M. G. P. M. S.; da Silva, F. D. C.; Ferreira, V. F.; Cavaleiro, J. A. S.; RSC Adv. 2015, 5, 66192.

232. Pereira, A. M. V. M.; Lacerda, P. S. S.; Silva, B. N. M.; Neves, M. G. P. M. S.; Silva, A. M. S.; Silva, B. V.; da Silva, F. C.; Ferreira, V. F.; Pinto, A. C.; Cavaleiro, J. A. S.; Dyes Pigm. 2017, 139, 247.

233. Santos, F. C.; Cunha, A. C.; de Souza, M. C. B. V.; Tomé, A. C.; Neves, M. G. P. M. S.; Ferreira, V. F.; Cavaleiro, J. A. S.; Tetrahedron Lett. 2008, 49, 7268.

234. de Oliveira, K. T.; Silva, A. M. S.; Tomé, A. C.; Neves, M. G. P. M. S.; Neri, C. R.; Garcia, V. S.; Serra, O. A.; Iamamoto, Y.; Cavaleiro, J. A. S.; Tetrahedron 2008, 64, 8709.

235. Foletto, P.; Correa, F.; Dornelles, L.; Iglesias, B, A.; da Silveira, C, H.; Nogara, P. A.; da Rocha, J. B. T.; Faustino, M. A. F.; Rodrigues, O. E. D.; Molecules 2018, 23, 2588.

236. da Silva, F. D.; Ferreira, V. F.; de Souza, M. C. B. V.; Tomé, A. C.; Neves, M. G. P. M. S.; Silva, A. M. S.; Cavaleiro, J. A. S.; Synlett 2008, 1205.

237. Gomes, A. T. P. C.; Faustino, M. A. F.; Neves, M. G. P. M. S.; Ferreira, V. F.; Juarranz, A.; Cavaleiro, J. A. S.; Sanz-Rodriguez, F.; RSC Adv. 2015, 5, 33496.

238. Diogo, P.; Fernandes, C.; Caramelo, F.; Mota, M.; Miranda, I. M.; Faustino, M. A. F.; Neves, M. G. P. M. S.; Uliana, M. P.; Oliveira, K. T.; Santos, J. M.; Gonçalves, T.; Front. Microbiol. 2017, 8, 498.

239. Silva, J. N.; Silva, A. M. G.; Tomé, J. P. C.; Ribeiro, A. O.; Domingues, M. R. M.; Cavaleiro, J. A. S.; Silva, A. M. S.; Neves, M. G. P. M. S.; Tomé, A. C.; Serra, O. A.; Bosca, F.; Filipe, P.; Santus, R.; Morlière, P.; Photochem. Photobiol. Sci. 2008, 7, 834.

240. Batalha, P. N.; Gomes, A. T. P. C.; Forezi, L. S. M.; Costa, L.; de Souza, M. C. B. V.; Boechat, F. D. S.; Ferreira, V. F.; Almeida, A.; Faustino, M. A. F.; Neves, M. G. P. M. S.; Cavaleiro, J. A. S.; RSC Adv. 2015, 5, 71228.

241. Lourenço, L. M. O.; Resende, J.; Iglesias, B. A.; Castro, K.; Nakagaki, S.; Lima, M. J.; da Cunha, A. F.; Neves, M. G. P. M. S.; Cavaleiro, J. A. S.; Tomé, J. P. C.; J. Porphyrins Phthalocyanines 2014, 18, 967.

242. Rodrigues, J. M. M.; Farinha, A. S.; Muteto, P. V.; WoranoviczBarreira, S. M.; Almeida Paz, F. A.; Neves, M. G. P. M. S.; Cavaleiro, J. A. S.; Tomé, A. C.; Gomes, M. T. S. R.; Sessler, J. L.; Tomé, J. P. C.; Chem. Commun. 2014, 50, 1359.

243. Santos, C. I. M.; Oliveira, E.; Menezes, J. C. J. M. D. S.; Barata, J. F. B.; Faustino, M. A. F.; Ferreira, V. F.; Cavaleiro, J. A. S.; Neves, M. G. P. M. S.; Lodeiro, C.; Tetrahedron 2014, 70, 3361.

244. Santos, E. M. G.; Couto, C. M. C. M.; Montenegro, M. C. B. S. M.; Neves, M. G. P. M. S.; Rebelo, S. L.; Cavaleiro, J. A. S.; Reis, B. F.; Anal. Bioanal. Chem. 2003, 375, 511.

245. Vinhado, F. S.; Gandini, M. E. F.; Iamamoto, Y.; Silva, A. M. G.; Simões, M. M. Q.; Neves, M. G. P. M. S.; Tomé, A. C.;
Rebelo, S. L. H.; Pereira, A. M. V. M.; Cavaleiro, J. A. S.; J. Mol. Catal. A: Chem. 2005, 239, 138.

246. Tomé, A. C.; Lacerda, P. S. S.; Neves, M. G. P. M. S.; Cavaleiro, J. A. S.; Chem. Commun. 1997, 1199.

247. Cavaleiro, J. A. S.; Tomé, A. C.; Neves, M. G. P. M. S. In The Porphyrin Handbook, vol. 2; Kadish, K. M.; Smith, K. M.; Guilard, R., eds.; Academic Press: San Diego, USA, 2010, p.158.

248. Barata, J. F. B.; Neves, M. G. P. M. S.; Faustino, M. A. F.; Tomé, A. C.; Cavaleiro, J. A. S.; Chem. Rev. 2017, 117, 3192.

249. Pires, S. M. G.; Paula, R. D.; Simões, M. M. Q.; Neves, M. G. P. M. S.; Santos, I. C. M. S.; Tomé, A. C.; Cavaleiro, J. A. S.; Catal. Commun. 2009, 11, 24.

250. Castro, K. A. D. F.; Pires, S. M. G.; Ribeiro, M. A.; Simões, M. M. Q.; Neves, M. G. P. M. S.; Schreiner, W. H.; Wypych, F.; Cavaleiro, J. A. S.; Nakagaki, S.; J. Colloid Interface Sci. 2015, 450, 339.

251. Paula, R. D.; Simões, M. M. Q.; Neves, M. G. P. M. S.; Cavaleiro, J. A. S.; Catal. Commun. 2008, 10, 57.

252. de Paula, R.; Simões, M. M. Q.; Neves, M. G. P. M. S.; Cavaleiro, J. A. S.; J. Mol. Catal. A: Chem. 2011, 345, 1.

253. de Paula, R.; Santos, I. C. M. S.; Simões, M. M. Q.; Neves, M. G. P. M. S.; Cavaleiro, J. A. S.; J. Mol. Catal. A: Chem. 2015, 404-405, 156.

254. Costa, J. I. T.; Tomé, A. C.; Neves, M. G. P. M. S.; Cavaleiro, J. A. S.; J. Porphyrins Phthalocyanines 2011, 15, 1116.

255. Castro, K. A. D. F.; Rodrigues, J. M. M.; Mendes, R. F.; Neves, M. G. P. M. S.; Simões, M. M. Q.; Cavaleiro, J. A. S.; Paz, F. A. A.; Tomé, J. P. C.; Nakagaki, S.; J. Catal. 2016, 344, 303.

256. Simões, M. M. Q.; Pires, S. M. G.; Neves, M. G. P. M. S.; Cavaleiro, J. A. S. In Handbook of Porphyrin Science, vol. 44; Kadish, K. M.; Smith, K. M.; Guilard, R., eds.; World Scientific Publishing: Singapore, 2016.

257. Neves, C. M. B.; Simões, M. M. Q.; Domingues, F. M. J.; Neves, M. G. P. M. S.; Cavaleiro, J. A. S.; Quim. Nova 2012, 35, 1477.

258. Neves, C. M. B.; Simões, M. M. Q.; Domingues, M. R. M.; Santos, I. C. M. S.; Neves, M. G. P. M. S.; Paz, F. A. A.; Silva, A. M. S.; Cavaleiro, J. A. S.; RSC Adv. 2012, 2, 7427.

259. Neves, C. M. B.; Simões, M. M. Q.; Santos, I. C. M. S.; Domingues, F. M. J.; Neves, M. G. P. M. S.; Almeida Paz, F. A.; Silva, A. M. S.; Cavaleiro, J. A. S.; Tetrahedron Lett. 2011, 52, 2898.

260. Neves, C. M. B.; Filipe, O. M. S.; Mota, N.; Santos, S. A. O.; Silvestre, A. J. D.; Santos, E. B. H.; Neves, M. G. P. M. S.; Simões, M. M. Q.; J. Hazard. Mater. 2019, 370, 13.

261. Pires, S. M. G.; Paula, R. D.; Simões, M. M. Q.; Silva, A. M. S.; Domingues, M. R. M.; Santos, I. C. M. S.; Vargas, M. D.; Ferreira, V. F.; Neves, M. G. P. M. S.; Cavaleiro, J. A. S.; RSC Adv. 2011, 1, 1195.

262. Cardoso, M. F. C.; Gomes, A. T. P. C.; Moreira, C. D. M.; Simões, M. M. Q.; Neves, M. G. P. M. S.; da Rocha, D. R.; 
da Silva, F. C.; Moreirinha, C.; Almeida, A.; Ferreira, V. F.; Cavaleiro, J. A. S.; Molecules 2017, 22, 1.

263. Bastos, M. M.; Boechat, N.; Gomes, A. T. P. C.; Neves, M. G. P. M. S.; Cavaleiro, J. A. S.; Rev. Virtual Quim. 2002, 4, 257.

264. Mesquita, M. Q.; Dias, C. J.; Gamelas, S.; Fardilha, M.; Neves, M. G. P. M. S.; Faustino, M. A. F.; An. Acad. Bras. Cienc. 2018, 90, 1101.

265. Mesquita, M. Q.; Dias, C. J.; Neves, M. G. P. M. S.; Almeida, A.; Faustino, M. A. F.; Molecules 2018, 23, 2424.

266. Gomes, A. T. P. C.; Neves, M. G. P. M. S.; Cavaleiro, J. A. S.; An. Acad. Bras. Cienc. 2018, 90, 993.

267. Maestrin, A. P. J.; Ribeiro, A. O.; Tedesco, A. C.; Neri, C. R.; Vinhado, F. S.; Serra, O. A.; Martins, P. R.; Iamamoto, Y.; Silva, A. M. G.; Tomé, A. C.; Neves, M. G. P. M. S.; Cavaleiro, J. A. S.; J. Braz. Chem. Soc. 2004, 15, 923.

268. Cerqueira, A. F. R.; Moura, N. M. M.; Serra, V. V.; Faustino, M. A. F.; Tomé, A. C.; Cavaleiro, J. A. S.; Neves, M. G. P. M. S.; Molecules 2017, 22, 1269.

269. Petrilli, R.; Praca, F. S. G.; Carollo, A. R. H.; Medina, W. S. G.; Oliveira, K. T.; Fantini, M. C. A.; Neves, M. G. P. M. S.; Cavaleiro, J. A. S.; Serra, O. A.; Iamamoto, Y.; Bentley, M. V. L. B.; Curr. Nanosci. 2013, 9, 434.

270. Mesquita, M. Q.; Menezes, J. C. J. M. D. S.; Neves, M. G. P. M. S.; Tomé, A. C.; Cavaleiro, J. A. S.; Cunha, Â.; Almeida, A.; Hackbarth, S.; Röder, B.; Faustino, M. A. F.; Bioorg. Med. Chem. Lett. 2014, 24, 808.
271. Mesquita, M. Q.; Menezes, J. C. J. M. D. S.; Pires, S. M. G.; Neves, M. G. P. M. S.; Simões, M. M. Q.; Tomé, A. C.; Cavaleiro, J. A. S.; Cunha, Â.; Daniel-Da-Silva, A. L.; Almeida, A.; Faustino, M. A. F.; Dyes Pigm. 2014, 110, 123.

272. Ribeiro, A. O.; Tomé, J. P. C.; Neves, M. G. P. M. S.; Tomé, A. C.; Cavaleiro, J. A. S.; Iamamoto, Y.; Torres, T.; Tetrahedron Lett. 2006, 47, 9177.

273. Ribeiro, A. O.; Tomé, J. P. C.; Neves, M. G. P. M. S.; Tomé, A. C.; Cavaleiro, J. A. S.; Serra, O. A.; Torres, T.; Tetrahedron Lett. 2006, 47, 6129.

274. Lourenço, L. M.; Sousa, A.; Gomes, M. C.; Faustino, M. A. F.; Almeida, A.; Silva, A. M.; Neves, M. G. P. M. S.; Cavaleiro, J. A. S.; Cunha, Â.; Tomé, J. P. C.; Photochem. Photobiol. Sci. 2015, 14, 1853.

275. Soares, A. R.; Tomé, J. P. C.; Neves, M. G. P. M. S.; Tomé, A. C.; Cavaleiro, J. A. S.; Torres, T.; Carbohydr. Res. 2009, 344, 507.

276. Lourenço, L. M. O.; Neves, M. G. P. M. S.; Cavaleiro, J. A. S.; Tomé, J. P. C.; Tetrahedron 2014, 70, 2681.

Submitted: February 23, 2019

Published online: July 4, 2019 